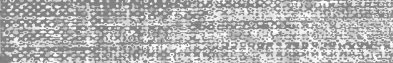
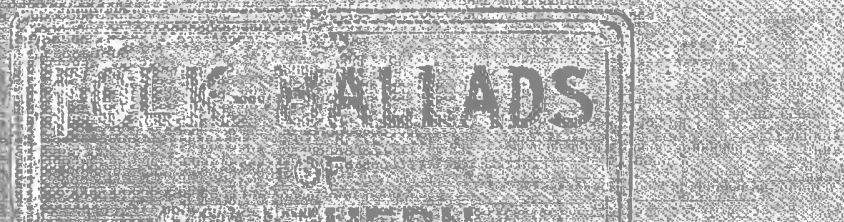

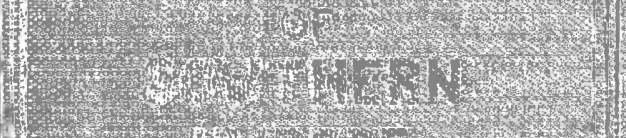

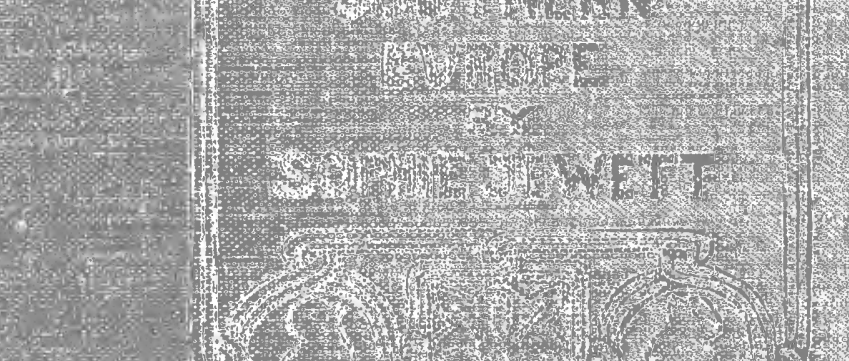

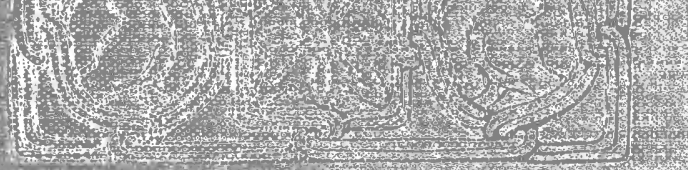

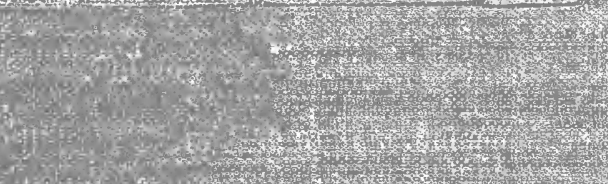

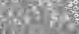

15.

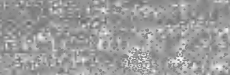

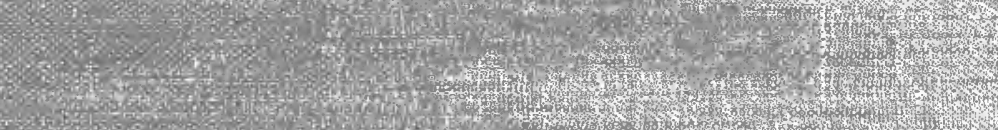
16. When

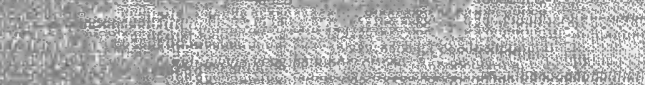

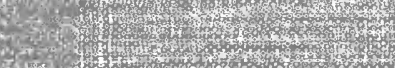

saxis

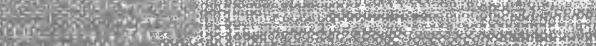
(1)

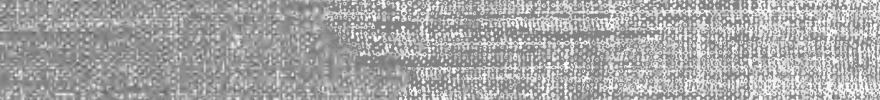

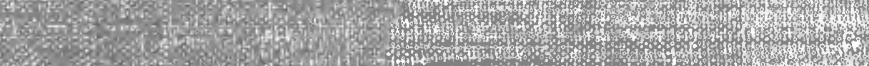
a 


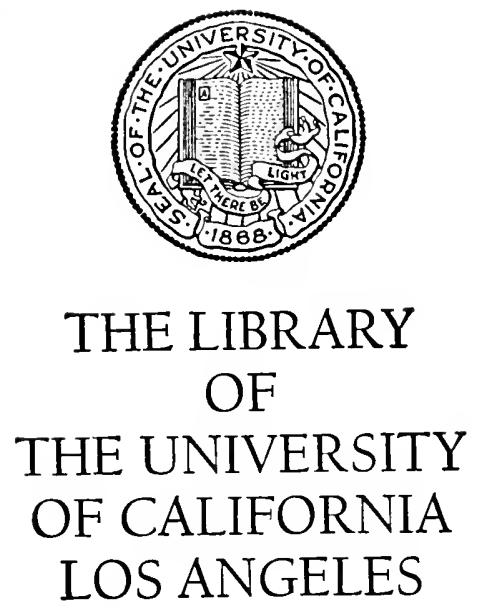

GIFT OF

Kate Gordon lioore 
Digitized by the Internet Archive in 2008 with funding from Microsoft Corporation 



\title{
Folk-Ballads of Southern Europe
}

Translated into English Verse

\author{
By \\ Sophie Jewett
}

G. P. Putnam's Sons

New York and London

Tbe knickerbocker Dresg

I9I 3 
COPYRIGHT, I9I 3

$\mathrm{BY}$

LOUISE R. JEWETT

Tbe Wknickerbocker Dress, Dew Work 


\section{PREFACE}

THIS illustrative selection, with translation, of 1 the ballads of Southern Europe grew quite simply from the effort to put into the hands of successive classes of Wellesley College students, studying English and Scottish popular ballads, analogous Continental folk-songs. Miss Jewett could easily bring to her classroom German ballads, as well as Scandinavian ballads in German and English translation, but for originals of many of the Southern analogues summarized in Professor Child's encyclopædic collection, which she deemed "as nearly perfect as is possible to any human achievement," she had to seek out, in the rich libraries of Boston and of Harvard, rare editions and old numbers of foreign reviews. The ballads so found were often in provincial dialects that might have baffled a less eager scholar, but it became one of her happiest pursuits to hunt down their inmost meaning and re-phrase it, poet that she was, in her own sympathetic translation. For the Roumanian ballads, although she pored over the originals, she had to depend, in the main, upon French translation, which was usually available, too, for the Gascon and Breton. Italian, which she 
knew well, guided her through obscure dialects of Italy and Sicily, but Castilian, Portuguese, and Catalan she puzzled out for herself with such natural insight that the experts to whom these translations have been submitted found hardly a word to change. "After all," as she herself wrote, "ballads are simple things, and require, as a rule, but a limited vocabulary, though a peculiarly idiomatic one."

In the summer of 1909, when Miss Jewett was silently facing the crisis that resulted in death, she revised these ballad translations and, on going to the hospital, left a written request that, if need be, I should, in case it seemed wise to publish them, prepare them for the press. At my first opportunity, late in coming, I searched out again the original texts and verified her copies. These texts are often irregular in punctuation, use of quotation points, and the like, but it has seemed the safer method to reproduce them, as a rule, exactly as they stand in the books from which they are taken. The order of the ballads I determined, as best I could, from scattered memoranda among her ballad papers. From these papers, too, I was fortunately able to glean, here and there, the material shaped into the following Introduction. In the brief annotation, for which her memoranda still afforded help, I have attempted little beyond the suggestion of the English analogues, though I have used the notes as an opportunity for introducing her various snatches of lyrical translation 


\section{Preface}

from these same folk-song volumes. These snatches, often lightly pencilled on a library slip, were found among her copies of ballad texts.

Katharine Lee Bates.

Wellesley College, Mass.

June 3, I9I2. 



\section{CONTENTS}

PAGE

INTRODUCTION $\quad . \quad$. $\quad . \quad . \quad . \quad . \quad$ I

BALLADS OF LOVE

The Sun and the Moon. (Roumanian) b 22

The Noble Sibilla. (Sicilian) . . . 30

The SAILor. (Catalan) . . . . 40

The Corsair. (Picdmontese) . . . 44

The Moor SaRicen. (Piedmontese). . 46

Cribete. (Gascon) . . . . . 50

Count Sol. (Castilian) . . . . 54

The Pilgrim. (Portuguese) . . . . . 62

Hero and Leander. (Piedmontese) . . 68

The Test. (Piedmontese) . . . . 70

Pierre of Grenoble. (French) • • . 72

The Dead Bride. (Piedmontese). . . 76

Catalinòta. (Piedmontese). . . . 78

Bridal Dance and Funeral. (Piedmontese). 80

Flowers from the Grave. (Piedmontese) • 82 
The Two Graves. (Piedmontese) . $\quad 84$

Count Arnaud. (Gascon) . . . . $\quad . \quad 86$

Count Anzolino. (Venetian) . . . 90

The Ring. (Neapolitan) . . . . $\quad$ • 94

The Shrine of San Simón. (Castilian) • 96

The Maiden in the Garden of Love. (French) 98

The Bird Messenger. (Piedmontese) . . Ioo

The King's Son. (Gascon) . . . . 102

Adieu, Margueridette. (Gascon) . . 104

BALLADS OF MURDER

Donna Lombarda. (Piedmontese) . . II2

The Poisoned Lover. (Piedmontese) . . II4

The Maiden of Saint-Martin-de-L'Ile. (French) . . . . . . $\quad$. 124

The Murder of the Sweetheart. (French) 128

Fair Jeanneton. (French) . . . . . 132

A Heroine. (Piedmontese) . . . . . I34

The Ballad of Rico Franco. (Castilian) . 138

Count Garí. (Catalan) . . . . . $\quad$ I 42

Lament of Maria Felice di Calacuccia for

the Death of her Brother. (Corsican) I 44

The Marquise. (French) . . . . . $\quad$ I 48 
BALLADS OF PRISONERS

BUjor. (Roumanian) . . . . . $\quad$. 154

The Brothers Fra Diavoli. (Sicilian) . I60

The Three Students of Toulouse. (Piedmontese) . . . . . . . I64

The Lads of Guérande. (French) . . $\quad$ I68

SHALGA. (Roumanian) . . . . 170

BIBLICAL AND APOCRYPHAL BALLADS

The Flight into Egypt. (Provençal) . . I80

Mary Magdalene. (Provençal) . . . 188

Saint Mary Magdalene. (Catalan) . . 192

The Samaritan Woman. (Catalan) . . 200

The Wicked Rich Man. (Provençal) • . 204

The Wicked Rich Man and the Beggar.

(Catalan) . $\quad . \quad$. . . . . 208

The Prodigal Son. (Sicilian) . . . 210

Saint James of Galicia. (Catalan) . . 218

BALLADS OF THE SUPERNATURAL

Count Arnold. (Catalan) . . . . 226

The Song of the Lost Soul. (French) • 244

The Young Girl and her Mother's Soul.

(Breton) . . . . . . . 246

The Dead Mother Restored. (Piedmontese) 250 
PAGE

The Mother's Curse. (Piedmontese) . . 252

The Accursèd. (Gascon) . . . . 254

The Voice from Uxderground. (Modern

Greek) . . . . . . 258

The Little Lamb. (Roumanian) . . . 260

Notes . . . . . . . . $27 \mathrm{I}$ 
Folk-Ballads of Southern Europe 


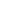




\section{Folk-Ballads of Southern Europe}

\section{INTRODUCTION}

SINCE the days of Southey's sojourn in the $\int$ Peninsula certain Spanish ballads have been familiar in English verse; and Lockhart's Spanish Ballads are almost as indispensable a part of one's early memories as are the lays of Robin Hood.

But Lockhart's ballads, like the originals from which they are translated, are only half "popular." In the Castilian, as in the English, there are bookish phrases and many a trace of courtly or school poetry. The French and Italian popular ballads have gained perhaps more than they have suffered by the fact that they have been collected since the time when improving and completing were admissible parts of an editor's task. Baldness, fragmentariness, inconsequence are marks of genuine transmission; while the variety without inventiveness displayed by a ballad that is found in a dozen different dialects is curiously interesting. Sometimes it suggests a typical provincial trait; some- 


\section{Folk-Ballads of Southern Europe}

times the reader fancies, if he lets himself fancy, that he catches the tone of unconscious individuality given by the particular peasant who repeated the particular song. The last point is too elusive to merit serious demonstration, but the former is a constant pleasure to one who turns the pages of Tuscan, Venetian, Sicilian, Neapolitan, Piedmontese collections; or who follows a ballad through its Provençal, Catalan, and Gascon versions.

This selection of ballads is too small to make possible any accurate comparison of Romance with Germanic ballads, and, moreover, it especially includes ballads that occur in both groups. All that such an attempt at comparison could do would be to note certain differences of form and of emphasis. Both in form and in subject one finds the same "stock material." Since all the ballads here given are to some degree analogues of British ballads they may be said to be all made of stock material. The most frequently recurring situations, so far as I have found, are those of the stealing of a bride or maiden; the feigning of death by a girl or lover; the test to prove the faithfulness of wife or lover; the pursuit of unreturning husband or lover; the effectiveness of omen or curse; the return of the dead to speak with the living. Among lesser but characteristic repeated traits are the magic power of music, the growth of flowers and trees from the graves of buried lovers, and the speech of inarticulate things. The resemblances in form are no less marked. 
There is the ballad which consists of riddling answer or repartee, as Adieu, Margueridette; the ballad that is built out by the slightest addition from stanza to stanza with what Professor Gummere calls "incremental repetition," as Count Arnold; the dramatic, dialogue ballad, as Donna Lombarda and The Poisoned Lover; the ballad running with a refrain, as The Corsair; the lyrical ballad that is scarcely more than a song, as The Ring; the epic ballad that relates adventure, as Count Sol.

It is, perhaps, more interesting to notice the ways in which the ballads of Romance countries differ from those of the North. I have found fewer long narrative ballads; on the other hand, the dramatic ballad, which is so noble in the British collections and quite as frequent there as the narrative ballad, is in Southern folk-song even more noteworthy. Edward Edward, Lord Randal, and Donna Lombarda illustrate the best that is possible to the dramatic ballad. If they do not interest and thrill us, we may as well give over the study of balladry, for it will not yield us greater examples. If we respond, on the other hand, to the appeal of these old songs, they "tease us out of thought," as Keats says, with desire to know more of a poetry that has persisted for centuries with no aid from scholar or printer. We think of Edward Edward as chanted beside a highland fire of a winter night, of Donna Lombarda sung by peasants resting in the hot vineyards of "the district of Pisa" waiting for the sea-wind to come at sunset, 


\section{Folk-Ballads of Southern Europe}

or perhaps, far earlier, in the sultry meadows within sight of Ravenna, where the memory of Queen Rosamund stalks like an unlaid ghost.

The first and largest group of ballads here given has to do with love, for in the faith of the true ballad-maker men have died, and women, for sheer love oftener than for other causes; and many times their deaths are told with sincere emotion. Count Arnaud's lady is as simply tragic as Brunhilde or Deirdre, and Catalinòta is as pathetic as Catarina. These ballads of death for love are not, however, always tragic nor even truly pathetic, but run all along from the fateful to the inconsequent and absurd, more than once strongly suggesting parody.

Though the man of the ballads is frequently both faithful and heroic, it is the woman to whom most often love is a thing to live and to die for. There are coquettes among the ballad women, but they are fewer than the faithful maidens and wives. The typical woman of the ballads, north or south, waits for her lover, follows him, dies of longing for him, or takes her own life when she has lost him. Among the best narrative ballads of lovers are those in which the lady is stolen by brigand or Saracen, and rescued by her Christian husband or lover. There is a great group of variants of the story of the bride carried away by a Moorish king and rescued by her husband after many years. These ballads are so excellent that it is difficult to choose among them. Count Nigra 
has made an exhaustive study of the whole group, giving (in his Canti Popolari del Piemonte, No. 40, Il Moro Saracino) about thirty versions. The Gascon version (Cribete) given by M. Bladé seems to me to possess almost all the excellencies of which narrative ballad is capable-swiftness of action, differentiation of character, irony, pathos, and tragedy. The refrain of this ballad would seem too artistic to be popular, were not so many haunting strains of lyric found among the Songs of the Soil. It is not perhaps more unexpected than the bride's reply to the Moor in the Piedmontese version: "He cannot be of my country. The birds of the air cannot come here; unless it be the swallow who flies all day."

In this group of love-ballads the transition is from ballads of love adventure by sea and land to those of untimely death for love, culminating in the haunting phrases of Count Anzolino, and then to folk-song of a lighter strain. The Scottish ballad is at its best when it has to do with tragedy. Dialogue like Edward Edward, narrative like The Mother's Malison, lyric lament like Bonny George Campbell best illustrate its passion and its music. Even across the southern border the great exception is that of the Robin Hood ballads. Apart from their splendid exhibition of humors, wit, gayety, daring, and generosity, most English ballads that rise to excellence are sorrowful. Of purely idyllic quality, of pathos without tragedy, of gayety without grossness, there is but little. 


\section{Folk-Ballads of Southern Europe}

It is natural that the Southern ballad, even when genuinely popular in origin, should offer illustrations of a temperament more lightly changing, of a sentiment more delicate and more selfconscious. The popular poet of the South can, if he please, jest daintily.

Closely related to the ballads of love are the ballads of murder, for except in the lays of border warfare and bandit life the ballad of murder is almost always a ballad of love and of jealousy. Although all European ballads of this class have much similarity of motif and situation, unpremeditated murder is far more frequent in Southern folk-song than in Northern. Murder and suicide of lovers, wife murder and husband murder, in even so northern a collection as Count Nigra's Canti del Piemonte, suggest the social world of I Pagliacci and Cavalleria Rusticana. Sometimes in their cold-blooded brevity these ballads read like the Italian daily papers. The ballad tale in which the husband murders the wife is very common on the Continent. The story of most of these ballads of slain women is summed up in a terrible bit of conversation in Margherita (Canti del Piemonte, No. 32):

"Pardon me, my husband; I am not by any means the first woman who has been untrue to her husband.'

"'You are not the first woman who has been untrue to her husband; neither am I the first man to kill his wife." 
In the murder-ballads the victim dies oftenest, perhaps, by the sword, but many times the death is from poisoned drink or food. In one rather modern French ballad ( $L a$ Marquise) the lady dies from the gift of poisoned flowers-not the only instance where a ballad seems to present the folk-version of some historic crime. Murder by the poison of serpents is a frequent motif, as in The Poisoned Lover, where venomous snakes were served for supper under the guise of eels. This ballad belongs in its central theme to most ancient and persistent romance. Who is the pitiless lady of the greenwood? Is she some popular version of La Belle Dame sans Merci, whose love is fatal to him who meets with her? In addition to this tragic figure, known through the length and breadth of Europe, of the lover who has supped with his false love and comes home to his mother to die, the murder-group presents interesting analogues to British folk-song in the ballads of quick-witted women who save themselves by slaying their would-be murderers. The woman has various devices to get the man into her power -borrowing his sword to cut a leafy bough for shading her horse, or to trim off the torn fringes of her mantle, or persuading him to stoop and draw off her shoes, but in the end her craft is ever stronger than his violence. Certain ballads of this class, as $A$ Heroine, suggest an offshoot from Bluebeard folklore. In The Murder of the Sweetheart there appears at her worst the sinister ballad- 


\section{Folk-Ballads of Southern Europe}

mother, whose counsel sways the wills of men, who is a kind of Fate to youth and maiden. By her inexorable command the son is brought to destroy what best he loves, to his own swift ruin. Such ballads give the heart of tragedy compressed into a few lines, but yielding all the complication of human motives and desires, of compunctions and recoils, that informs the drama of crime.

The greatest of all murder-ballads is the famous Donna Lombarda. No one knows how old it may be, but the name, the nature of the crime and its manner point back to a sixth-century original, the history of Rosamund, Queen of the Lombards. If this be so, it is not an isolated instance of the unappeasable vengeance of popular ill fame. But for folk-song, the crimes of Edom o' Gordon and of Mary Hamilton might be forgotten. It is no wonder that Helen, bewailing the mischief she has wrought and the doom of the gods, laments most bitterly the lot of herself and of her husband for that "even in days to come they may be a song in the ears of men that shall be hereafter" (Iliad, vi., 357-8). In spite of great beauty and power, Swinburne's drama of Rosamund is unconvincing beside the grim terror of the ballad, where passion, jealousy, suspicion, and vengeance use naked words like swords. Swift and brief as it is, nothing that goes to the making of supreme tragedy is absent. Othello's "Thou art to die" is not more unappealable than the husband's "Drink with me then, Donna Lombarda"; and 
all the flower-like phrases with which Swinburne's Rosamund deceives Albovine wither beside the desperate simplicity of Donna Lombarda's evasion:

"There came the sea-wind last night at sunset; It clouded the wine."

Though the code of the ballad is far from conventional morality, retribution commonly follows close on crime. The most primitive and most poetic punishment is, of course, not legal execution; it is either some Nemesis of Nature or, more often, the vendetta. Certain crimes against society are avenged by the injured. The stealing of a maiden instantly brings father and brothers in pursuit. Border thieving is likely to be met by reprisal from the chief sufferers, without recourse to law. The enveloping world of Nature, too, is conscious of human action; bird or harp will find speech to betray the guilty secret, however strictly guarded. And visible Nature is mysteriously related to a more terrible realm of the unseen. When human agents and all the animate world have proved harmless to the criminal, the very graves give up their dead to reproach or to convict.

The social ideal of the ballads is democracy. The ballad hero may be bandit, outlaw, felon, but he champions the lowly and defies the tyrant. Pride and courage go with him to the scaffold and his shameful death becomes sweet in peasant song. 


\section{Io Folk-Ballads of Southern Europe}

The Roumanian ballads, especially, are permeated with this hatred of oppression, this passionate sympathy for the sorrows of the poor, the outcast, and the prisoner.

The people of the little Balkan kingdom of Roumania appeal in rare degree to one's imagination; their songs are bewilderingly and fascinatingly reminiscent of their mingled blood and composite temperament. For the modern Roumanians, deeply tinged as their spirit is by the Slavic, are far-away descendants of those Roman colonists established in the district during the second century by the great invasions of the Emperor Trajan. The Roman tradition and the Roman traits have persisted through the ravages of Goths and Huns, of Turks and Russians. Pride in their Roman origin has outlasted all the ages of conflict and even their achievement of national independence in the last quarter of the nineteenth century. It is an old story that Roman colonists and exiles, homesick for Italy, were wont to name the Milky Way the Road to Rome; so the Roumanian even to-day looks up to that white, splendid path and calls it Trajan's Road; and the thunder he calls Trajan's Voice. A Roumanian fairy tale is of the poet Ovid, exiled to a desolate place near the Black Sea; and of an enchanted island whither he was lured by a pet snake, the one companion of his solitude, and where he saw superb men and women like those whom he had known in Rome-men and women who were sud- 
denly transformed into serpents before the wistful eyes of him who wrote the Metamorphoses. Bits of classic mythology survive in narrative ballads, Roman names, and even distorted incidents of Roman history. The four examples of Roumanian folk-song translated in this volume-the opening ballad, an Apollo myth strangely touched with Christian lights and shadows, the closing ballad, poignant with human pathos, yet most beautiful of all, and the two ballads in the prisoner group, one of Bujor the victim, one of Shalga the deliverer -all illustrate that romantic high-heartedness of the Roumanian peasant. Soldierly courage, gallant welcoming of death, and a patriotism nerving to perilous adventure women as well as menthese things, with love of youth and beauty, love of space and freedom, love of music, weave a resistless charm. Always there is the consciousness of the outward world as living and holding fellowship with human beings, always the thought of the dead as still retaining a dim, imprisoned life, not utterly cut off from communion with those who "walk under the moon."

The Roumanian ballads of adventure, many of them substantially historic, recall, in spite of pronounced differences, the English and Scottish ballads of the Border, but the Roumanian heroes are marked by a certain wild majesty and gypsy grace. Bujor, whose name signifies Peony or The Red-head, was a Moldavian brigand, a popular hero, "pitiless toward officers of Govern- 


\section{I2 Folk-Ballads of Southern Europe}

ment, and toward nobles; he was, on the contrary, most gracious toward peasants and the unfortunate." These characteristics are those of the ideal outlaw from the days of Sherwood Forest to the present. The Sicilian brothers, Fra Diavoli, are more of the dare-devil type, but their maddest exploits are tame before the whirling battle-ax of Shalga, that glorious young Amazon who rides to the rescue of her shepherds

\section{"High upon the Danube shore."}

The English and Scottish ballads based upon Scriptural or Apocryphal stories are very few. In all Professor Child's collection there are but six (Nos. 21, 22, 23, 54, 55, 56) and one of these (No. 21, The Maid and the Palmer) is scarcely recognizable as the degenerate form of the story of the Samaritan woman, having almost nothing in common with its beautiful Southern analogues. For ballads of the Passion of Christ, one should turn to the Celtic. I know nothing in the Continental folk-poetry that compares in sorrow and in horror with the Irish Keening of the Three Maries (see J. M. McCarthy's Irish Literature, vol. x., p. 3789, for "A Traditional Folk-Ballad translated by Douglas Hyde"). It is natural that the popular poetry of Roman Catholic peoples should be rich in ballads of miracle, of penitence, and of punishment; of the lives of the Virgin Mary, of Mary Magdalene, of the Child Jesus. Reading our own 
exquisite Cherry Tree Carol (Child's Collection, No. 54) makes one wonder regretfully how many other versions of sacred legend have been lost in the countries of Wyclif and Knox.

In a sense, the religious ballads are not "popular." Their content is to a degree bookish, obtained through the instruction of the Church, yet nowhere, except in the ecclesiastical drama, is the popular handling of familiar matter so interestingly evident. The two New Testament stories that have the widest circulation among these ballads are that of Dives and Lazarus, and that of Mary Magdalene. In both the characters have become, as it were, popular-even provincial -types. Lazarus stands for the mendicant class, and Dives for all that is pitiless and unjust in social conditions. Many times in the ballad the persons of the parable disappear altogether, and the story is only of the prosperity and the punishment of a nameless rich man who refused charity to the poor. From France alone, one could make a volume of such ballads, many of them merely gruesome, but representing as a whole the protest and the consolation of the proletariat. M. Victor Smith, describing (in Chants de Pauvres, Romania, vol. ii., r873) the singing of the beggars on feastdays about 1830 , says that their favorite songs were "those where Jesus made himself one with them, becoming mendicant like them, those where the wealthy miser is punished in hell, or the generous alms-giver rewarded with prompt entrance 


\section{I4 Folk-Ballads of Southern Europe}

into heaven, those where paradise is shut to the rich to be opened to the poor." And Damase Arbaut writing (in Chants Populaires de la Provence, vol. i., p. 58) of Provence about I860 says: "The parable of Dives is still the favorite song of the beggars."

In English and Scotch folk-song, we have no genuine representative of the Continental cycle of Magdalen ballads. Analogous to The Maid and the Palmer are some twenty Scandinavian ballads where, as there, the treatment of the woman is gross and where the story of the Samari$\tan$ is confused with that of Mary Magdalene. In the South, besides ballads of the Samaritan woman, there are many ballads of Mary Magdalene, assumed to be identical with the woman "which was a sinner" (Luke vii., 37) and also with Mary, the sister of Lazarus and Martha. The Magdalen of these ballads is a most appealing figure, curiously like, and unlike, the type of the painters. She is beautiful or pretty, vain, loving finery, loving love, but turning to Him who reveals her own soul to her with all the abandonment of devotion that she has lavished upon earthly loves. Many of the ballads of the Magdalen end with her glorious transit to Heaven, attended by Mary Virgin, saints, and angels. In this ending the human pathos of the character, a typical sinful woman turned whole-heartedly to penitence, is greatly weakened. The Provençal version given by Arbaut seems to me more dramatic in its 
incompleteness than the others, though it lacks the keen characterization of the Catalan.

These religious ballads vary in excellence from best to worst specimens of popular poetry exactly as the religious literature of the schools varies from greatest to least, and for like reasons. Where the ballad is made to enforce a dogma, or to arouse a fear, it may be execrable, but where a story from the New Testament or from the legends of the Nativity has taken hold upon a simple imagination, one finds such clever provincial characterization as in that piece of modern tragi-comedy, the Sicilian version of The Prodigal Son, and often, too, a devoutness as sincere as its expression is naive.

The superstition that pervades European folklore is sometimes curiously interwrought with Christianity and sometimes frankly pagan. The unschooled imagination turns constantly to the supernatural to account for the mysterious, the unexplained, and readily finds in mere sequence of incidents relations of cause and effect. A mother in anger curses her child, and the child, departing from home, is overtaken by fatal disaster. The inference is plain. It is the mother's malison (Child, No. 216) that brings Sweet Willie to his death in the roaring Clyde; it is the mother's curse that makes the little bride unable to hold fast to her lover at the perilous ford.

"My mother she has cursed me;

And the curse of a mother or a father must come true." 


\section{I6 Folk-Ballads of Southern Europe}

This is the convincing logic of events from which the poetic imagination, be it that of crowned genius or of village minstrel, creates tragedy.

Portent in ballad poetry is as inexorable as malediction. The new moon is seen "with the auld moon in her arm," the sign of storm and shipwreck, and Sir Patrick Spens (Child, No. 58) goes to his death with as strong a sense of fate upon him as had Beowulf when he fought the fire-drake. It is only the sophisticated mind that has noted how often the event belies the omen. There is a fine, unconscious logic, too, in the belief that crime, concealed from human knowledge, must yet be revealed-a belief that has colored all literature since the blood of Abel cried from the ground. The popular conceptions are no less poetic than the classic. We do not, in the ballads, see the comet flaring through the heavens as over Rome

"A little ere the mightiest Julius died,"

but (Child, No. 68 C)

"Aboon the place Young Riedan lies

The cannels burn bricht."

We do not hear the boding cry of Cassandra as she recoils from the threshold of Agamemnon's palace, but the cawing of the three ravens (Child, No. 26) guides the seeker to the slain knight, and the yellow harp-strings (Child, No. Io), wrought of drowned maiden's hair, wail the words: 
"Wae to my sister, fair Ellen!"

It is all one-shriek of Greek prophetess or croak of corbie; "if these should hold their peace, the stones would immediately cry out."

If ballad poetry finds much material in omen, portent, and curse, in the voices of birds, the cries of water-kelpie or banshee, in the speech of things inarticulate-if the natural world in which folk live thus goes hand in hand with the supernatural, inevitably it must communicate with the world of the dead. The few ghost-ballads of Britain, including at least two that are superlatively good, ally themselves with a great group of Continental analogues, among which are some of the finest ballads in existence. A main theme of these is spirit visitation, the causes that disturb or call back departed souls being: the grief and tears of the living for the dead; the desire of the dead lover to receive back his troth, without which he cannot rest; the lover's longing to carry his living sweetheart to the world of the dead; the sufferings of the living, especially of children ill-treated or neglected; hurt pride because the grave has been trodden by careless feet, or grazed by cattle; the desire to redress or expiate crimes committed in life; the desire like that of Dives in Hell to warn the living of the punishment that follows sin.

I know of no Southern analogues to the beautiful Northern ballads of the ghostly lover. It is probable that these ballads are, as Professor 


\section{Folk-Ballads of Southern Europe}

Child points out (in his notes to Sweet William's Ghost, vol ii., p. 228), related to the tale of Helgi and Sigrún in the Elder Edda. The heroic traits of this magnificent epic fragment belong to a greater art than that of ballad-making, but the ballads have preserved the human pain and wistfulness, the wonder of the living at the touch of the dead, and the passionate yearning to share the fate of the belovèd.

The teachings of the Church give, here and there, an ethical note to the ghost-lore, as in the remorseful craving of the spirit to return for the repairing of a wrong or for the warning of his kindred that they may escape his doom. More rarely the touch of Christianity imparts an unwonted gentleness or grace, as in The Wife of Usher's Well (Child, No. 79), most perfect of British ballads. Here the widow's three sons, in hats of the birk that grew fair at the gates of Paradise, come home to their mother for a night, not to complain of her weeping, but simply to comfort her by their presence. Commonly, however, the phantom ballads, in their passage from paganism, take on only the new horror of Purgatory and of Hell. The imagination of the peasant poet, excited and tantalized by the pictures, plays, and sermons of the Church, revels in fantastic torments. The French and Spanish ballads, especially, paint the tortures of the damned with all the hideousness, though not the power, of Dante's Inferno. Yet sometimes, as in the pitiless Catalonian ballad of 
Count Arnold, who had been an unjust master, there is even more spiritual terror than ghostly horror. The wages of sin and the relentlessness of judgment are most made manifest, not in the flaming apparition, but in the shuddering agony of the loyal wife, whose love cannot deny his guilt nor the awful justice of his punishment.

Yet for all this lurid ecclesiastical coloring, the conception of the dead as restless, earth-bound, haunters of the scenes they knew in life, is pagan, even though that which holds them from peaceful union with death is the lamentation of those who love them, or their own concern for those they love. The theme of a mother-ghost stealing from her grave to care for her misused children does not belong to British balladry, but is common in Continental folk-lore, both Germanic and Southern, being of widest diffusion in France. The ballad in which, perhaps, there is most of the pagan passion for life and youth is a brief one from the Modern Greek. Not even in Roumanian folk-song have I found such agony of resentment against death as cries in this "voice from underground."

"Perhaps I was not young, I too! Was I not brave? Have I not walked, I too, by night under the moon?"

And where in ballad-lore outside of the Roumanian does one find death so clothed upon with pagan beauty and majesty as in the exultant vision of the young Moldave? 


\section{Folk-Ballads of Southern Europe}

". . no word shalt thou tell'

In what wise my death befell;

Say I wed a royal bride,

Wooed of all the world beside;

Say that when our faith was given,

A bright star fell out of heaven; Sun and moon stood holding there A marriage-wreath above my hair; Mountains tall were priests to me; Guests were pine and alder tree; Torches were the flaming stars, Thousand birds my lute-players." 
Ballads of Love 


\section{SÓRELE ŞI LUNA}

Âmbla, frate, mândrul sóre

Âmbla, frate, se se 'nsóre

Noă ă̆,

Pe noă că̌

Care nóptea pascŭ în ralu, Âmbla cerŭul și pamîntul

Ca săgéta şi ca vîntul, Dar toțĭ cai'şĭ obosĭa

Şi potrivă nu'şu găsĭa

$\mathrm{Ca}$ sora sa Ileana

Ileana Cosinzana,

Ce-1̆ frumósă ca o flóre Într'o érnă fără sóre.

— "Sorióră Ileano

Ileano Cosinzano!

Haĭdeţu se ne logodim

C'amîndoĭ ne potrivim

Şi la plete şi la feçe

Si la dalbe frumusețe.

Eŭ am plete strelucite,

$\mathrm{Tu}$ aĭ plete aurite,

Eŭ am faç̆a arḑŭtóre

Tu, façùa mîngăetóre.

-Ale1̌! frate luminate, Trupuşor făr' de pacate, 


\section{THE SUN AND THE MOON}

\section{(Roumanian)}

Brother! on a day, the Sun

Was filled with great desire to wed;

For nine years, drawn by nine steeds, Heaven and earth he travelèd, Swift as arrow or as wind; But in vain he tired his steeds, Nowhere, nowhere could he find For himself a worthy bride, None whom he might place beside Helen, his own sister fair, Helen of the long gold hair.

To his sister then he goes, Speaking in the voice she knows:

"Helen, little sister fair, Helen of the long gold hair, Wilt thou not be wed with me?

For we are alike to see:

Like in feature, like in hair, Like in beauty past compare; I have glittering rays of light, Thou hast tresses gilded bright; All my face is shining clear, And thy face is radiant, dear!" "Oh, my brother, light of earth, Thou who from all sin art pure, 


\section{Folk-Ballads of Southern Europe}

$\mathrm{Nu}$ se află-adevĕrat

Fraţŭ se se fi cununat.

Cată'ţĭ tu de cerĭul teŭ

Şi eŭ de pămîntul meŭ

C'aşa vrut-a Dumneđ̧eŭ."

Sórele se 'ntuneca,

Sus, la Domnul se urca,

Domnulư̆ se închina

Şi din gură cuvînta;

"Dómne sfinte,

Şi părinte!

Mie timpul mŭ-a sosit,

Timpul de căsătorit,

Şi potrivă n'am găsit

Ca soră mea Ileana

Ileana Cosinzana."

Domnul sfînt îl asculta

Şi de mână mi'1 lua

Şi prin ıadurĭ mi'l purta

Dór că l'ar înspăǐmînta,

Si prin raĭu încă '1 purta

Dóră că l'ar încănta,

Apoĭ Domnul Dumneđ̧eŭ

Cuvînta cu graĭul seŭ,

Ear când Domnul cuvînta,

Lumile se destepta

Şi cu drag îl asculta.

Cerurile strelucia,

Noriü din senin peria:

"Sóre, sóre luminate,

Trupuşor făr' de pacate

Raĭul tu l'aĭ petrecut

Şi prin rad încă-aĭ trecutŭ,

Ce maĭ dice ghîndul teŭ? 


\section{The Sun and the Moon}

Never since the world had birth,

Never was it known, be sure, Brother might with sister wed;

That were dreadful sin," she said.

At these words the Sun grew dim; And he mounted to God's throne, And he knelt before the Lord, With his own voice spoke to Him: "Holy God! Father!" he said, "It is time that I should wed, But alas! I cannot find. Anywhere a worthy bride, One whom I may set beside Helen, my own sister fair, Helen of the golden hair."

And the Lord God listened well: Then He took him by the hand, Led him through the paths of Hell, That his heart might understand All the terror of the place;

Led him then through Paradise, To enchant him, soul and eyes.

Then the Lord God spoke and said: (While the Lord God spoke that day All the sky shone clear and gay;

Every dim cloud vanishèd.) "Sun," He said, "thou radiant Sun, Thou who from all sin art pure, Thou hast been in Paradise, Thou hast walked the paths of Hell, Of the two thou must choose one." 
-Dice că sufletul meŭ, Aleg radul chĭar de viŭ

Numal̆ singur se nu fiŭ,

$\mathrm{Ci}$ se fiŭ cu Ileana

Ilcana Cosinzana!"

Sórele se coborĭa

La sora luĭ se oprăa,

Mîndră nuntă pregătĭa,

Pe Ileana ş̌̆-o gatı̌a

$\mathrm{Cu}$ petélă de mirésă

Cunună de 'mperatésă,

Şi rochița nețesută,

Din petre scumpe bătută.

Apoŏ mîndri, el şi ea

La biserică mergea.

Dar când nunta se făcea,

Vaĭ de el, amar de ea!

Candelile se stingea

Clopotele se dogea,

Sfinţii façì 'şĭ ascundea

Preoţŭ în genuchĭ cădea.

Ear mirésa, vaĭ de ea!

Frig de mórte-o coprindea

Căcĭ o mână se 'ntindea

Şi pe sus o redica

Şi 'n mare mĭ-o arunca!

Valurile bulbucĭa,

Ear ea 'n valurĭ cum trecea

Mrénă de-aur se făcea.

Sórele se 'nălţa sus.

Se lăsa tot spre apus

Şi 'n marea se cufunda

La soră sa Ileana

Ileana Cosinzana. 


\section{The Sun and the Moon}

Gayly answered then the Sun:

"Hell I gladly will endure,

If alone I need not dwell,

But with my own sister fair,

Helen of the long gold hair."

From the sky the Sun went down

To his sister's house that day;

Set the wedding in array;

Placed on Helen's brow so fair

The golden fillet brides should wear;

On her head a royal crown;

Dressed her in transparent gown,

With white pearls embroiderèd.

To the great church to be wed

Went they straightway, he and she.

When the service is begun,

Woe to her and woe to him!

All the lamps turn dark and dim;

The bells crack, and crashing fall

Rail and rood and choir-stall;

On its base the clock-tower sways;

Dumb the priest stands where he prays,

And his vestments fall from him.

Woe to Helen! sad to tell

How a hand invisible

Seizes her from out the place,

Hurls her through the vast of space,

Hurls her down into the sea,

Where she changes suddenly

To a fish with scales of gold. 


\section{Folk-Ballads of Southern Europe}

Eară Dumneđ̧eŭ cel sfînt Sfînt în cer şi pre pămînt,

Mâna 'n valurĭ că băga

Mreana 'n mână-o apuca

Şi 'n cerüurĭ o arunca

Şi 'n lună plină-o schimba.

Apoŭ Domnul Dumneḑeŭ

Cuvînta cu graĭulŭ seŭ;

Ear când Domnul cuvînta

Lumile se spăìmînta

Mările se tupila,

Munţiĭ se cutremura

Ceriul se întuneca:

"Tu, Ileană Cosinzană

Sufleţel fără prihană,

Şi tu, sóre luminate

Trupuşor făr' de pacate!

Cu ochii se vĕ zărițĭ

Dar se fiţ̌ tot despărţiţ̌̆.

Ḑi şi nópte plinĭ de dor,

Arş̌ de foc nestingĕtor,

Vecĭnic se vĕ alungațĭ

Cerĭul se cutrieraţ̆

Lumile se luminaţ̌!!"

Alecsandri, Vasile: Poesið Populare ale Românilor (Bucuresc', 1866), pp. 27-30. 


\section{The Sun and the Moon}

Then the Sun pales, even he,

And he mounts the vaulted sky,

And he sinks down toward the west,

Plunges deep into the sea,

Seeking her he loves the best,

Helen, his own sister fair,

Helen of the long gold hair.

Then the Lord God from on high,

Holy Lord of earth and sky,

Took the gold fish in his hand,

Hurled it once again through space,

Changed it of his wondrous grace

To the moon with shining face;

And the Lord God spoke again:

(When the Lord God spoke that day,

Stars and worlds shook far and near,

But the sea-waves calmer lay,

And the mountains bent to pray,

While men trembled in their fear.)

"Helen of the long gold hair,

And thou Sun so shining fair,

Thou who from all sin art pure,

Sun and Moon ye are condemned,

While my heavens shall endure,

Till eternity shall end,

To seek each other through the skies,

Following with yearning eyes;

Never having power to meet

On the high celestial street,

Only following endlessly,

Lifted over earth and sea,

Wandering heaven day and night,

Filling all the worlds with light." 


\section{Folk-Ballads of Southern Europe}

\section{SCIBILIA NOBILI}

La figghia di lu re'mprincipi

Chi si cerca a maritari

Porta setti aneddi a jidita

E quattordici schivani.

Sta nova jiu 'nsina 'n Tunisi, Unni chiddru malucani

Armau setti galeri

Tutti setti 'capu la navi

$\mathrm{Cu}$ triccentu marinari.

Quannu fôru 'mmeru a lu portu

Li birritti si cangiaru

$\mathrm{Pi}$ pariri cristiani.

Si nni jeru nni Scibilia nobili:

"Scibilia nobili, aprimi, aprimi."

"E no no 'un ti pozzu apriri,

Chi lu mè spusu è à cacciari."

La porta 'n terra cci sbalancaru

A Scibilia nobili si pigghiaru

Cu' 'nu peri e cu' 'na manu

Supra la navi si la purtaru.

E po' vinni lu sò spusu

Ed accuminciau a spiari:

"Scibilia nobili unn'è, unn' eni?"

"Si la pigghiaru li marinari." 


\section{The Noble Sibilla}

\section{THE NOBLE SIBILLA}

(Sicilian)

The daughter of a line of princes;

$\mathrm{Oh}$, she was very fair to wed; She wears seven rings upon her fingers,

Twice seven veils upon her head.

The fame of her has spread to Tunis,

To Tunis where the pirates be;

And they have armed their seven galleys,

And all the seven set to sea;

Seven galleys and three hundred seamen

They have set out upon the sea.

They come a-sailing into harbor, And every crafty blackamoor

Has dressed himself like to a Christian

To go unto the lady's door.

"O Sibilla! O noble lady!

Open, I pray, thy door to me!"

"My husband he is gone a-hunting,

I cannot open unto thee."

The blackamoors they will not listen,

But they have broken in the door;

By hands and feet they seize the lady,

And carry her down to the shore.

The husband comes home from his hunting

And all the people, weeping, say:

"She is not here, thy noble lady,

The Moors have stolen her away." 


\section{Folk-Ballads of Southern Europe}

Si nn' ha jutu a la marina

Lacrimi all' occhi, li manu sbattennu,

"Jeu vi dugnu oru e dinari

Pi quantu iddra pò pisari."

"Puru chi mi nni inghissi navi

E no no 'un ti l'haju a dari."

"E signuri Ginerali,

E facitimilla affacciari

Quantu ci dicu du suli palori.

"Scibilia nobili, Scibilia nobili,

Comu ti facisti pigghiari ?

Mi lassasti lu figghiu picciulu,

E cu' minna cci voli dari?

Si nurrizza 'un cci nn'è no,

Pani e nuci cci pascird."

E supra li tri ghiorna

Cci dissiru: "Vô' mangiari?"

"Nè mangiari, nè bivìri,

Nè durmiri nè stari beni,

Nuddru pinseri a mia mi nni veni

Chi lu mè figghiu è mortu di fami."

Li marinari s'addrumisceru;

Cadíu la bella dintra lu mari;

Scali di sita pi li marinari

Pi pigghiari la bella 'nta mari. 


\section{The Noble Sibilla}

The husband goes down to the harbor,

His tears are falling like the rain;

"Oh, I will load your ships with treasure;

Give me my noble bride again."

"Though you should load my ships with treasure Until they sink into the sea;

Though you should load my ships with treasure, Your noble lady stays with me."

"O noble captain of the galleys,

Listen, and do me this one grace, That I may speak here with my lady, And look once more upon her face."

"O Sibilla, my noble lady!

How couldst thou let them take thee thus?

Thou hast left thy little son behind thee,

Tell me what will become of us?

How shall I feed him lest he die?

And who will sing his lullaby?"

After three days the sailors beg her:

"O noble lady, eat and drink."

"I have no wish for eating, sleeping,

For always on my house I think.

Only one thing can do me good,

To give my starving baby food."

The mariners they lie a-sleeping;

She throws herself into the sea;

But they have made them silken ladders

And drawn her out full skillfully. 


\section{Folk-Ballads of Southern Europe}

E la navi vôta e firria

E la bella chiancennu va.

"Marinaru, marina, marona,

Sammi a diri chi ventu fa,

S'è sciloccu o tramuntana

Nni mè patri mi purtirò.

Miu caru patri, miu caru patri,

Mi vuliti riscattari ?"

"Mia cara figghia, mia cara figghia,

Quantu è lu ricàttitu tô?"

"Tri liuna, tri farcuna,

Quattru culonni chi d'oru su'."

"Nun pozzu perdiri ssi dinari,

Quantu è megghiu ti perdi tu!"

"Vôi mangiari, vôi mangiari?"

"Nè mangiari, nè bivìri,

Nè durmiri nè stari beni,

Nuddru pinseri a mia mi nni veni

Chi lu mè figghiu è mortu di fami."

Si nn' ha jutu a la marina

E la navi vôta e firría

E la bella chiancennu va.

"Marinari, marina, marona,

Sammi a diri chi tempu fa,

S'è sciloccu o tramuntana

Nni mè matri mi purtirò. 


\section{The Noble Sibilla}

And now the ship goes sailing, swinging, And the fair lady goes a-singing:

"O sailor, sailing, always sailing,

Tell me how does the sea-wind blow;

$\mathrm{Be}$ it the South wind, be it the North wind,

To my father I will go."

"O my father, my dear father!

Wilt thou not come and ransom me?"

"O my daughter, my dear daughter,

Tell me what must thy ransom be?"

"Three gold lions, three gold falcons,

Four gold columns it must be."

"I cannot part with so much treasure, How much better to part with thee!"

"Wilt thou not eat and drink, fair lady?"

"Oh, no, I cannot eat nor drink.

What should I do with eating, sleeping,

When always the same thought I think?

My baby dies for lack of food,

What meat or drink can do me good?"

The ship close to the shore goes driving,

It turns and goes a-sailing, swinging,

And the fair lady goes a-singing:

"O sailor, sailing, always sailing,

Tell me how does the sea-wind blow?

Be it the South wind, be it the North wind,

To my mother I will go." 


\section{Folk-Ballads of Southern Europe}

Mia cara matri, mia cara matri,

Mi vuliti arriscattari?"

"Mia cara figghia, mia cara figghia,

E quant' è lu ricàttitu tô?"

"Tri liuna, tri farcuna,

Quattru culonni chi d'oru su'."

"Nun pozzu perdiri ssi dinari,

Quantu è megghiu ti perdi tu!"

"Vôi mangiari, vôi vivìri,

Vôi durmìri, vô' stari beni?"

"Nuddru pinseri a mia mi nni veni

Chi lu mè figghiu è mortu di fami."

Si nn'ha ghiuta a la marina

E la navi vôta e firría

E la bella chiancennu va.

"Marinaru, marina, marona,

Sammi a diri chi tempu fa,

S'è sciloccu o tramuntana

Nni mè frati mi purtirò.

Miu caru frati, miu caru frati,

Mi vuliti arriscattari?"

"Mia cara soru, mia cara soru,

E quant' è lu ricàttitu tô?"

"Tri liuna, tri farcuna,

Quattru culonni chi d'oru su'."

"Nun pozzu perdiri tuttu ss' oru,

Quant' è megghiu ti perdi tu!"

Si nn' ha ghiuta a la marina,

E la navi vôta e firría

E la bella chiancennu va.

"Marinaru, marina, marona,

Sammi a diri chi tempu fa, 


\section{The Noble Sibilla}

"O my mother, my dear mother!

Wilt thou not come and ransom me?"

"O my daughter, my dear daughter, Tell me what must thy ransom be?"

"Three gold lions, three gold falcons, Four gold columns it must be."

"I cannot part with so much money, How much better to part with thee!"

"Wilt thou not eat and live, fair lady?

Wilt thou not sleep and do thee good?" "Only one thought I 'm always thinking, My little baby dies for food."

Now close along the land they 're driving, But the ship goes sailing, swinging, And the fair lady goes a-singing: "O sailor, sailing, always sailing, Tell me how does the sea-wind blow?

Be it the South wind, be it the North wind,

To my brother I will go."

"O my brother, my dear brother!

Wilt thou not come and ransom me?"

"O my sister, my dear sister,

Tell me, what must thy ransom be?"

"Three gold lions, three gold falcons, Four gold columns it must be."

"I cannot part with so much treasure, How much better to part with thee!" And now along the shore they 're driving, But the ship goes sailing, swinging, And the fair lady goes a-singing: "O sailor, sailing, always sailing, Tell me how does the sea-wind blow? 


\section{Folk-Ballads of Southern Europe}

S'è sciloccu o tramuntana

Nni mè soru mi purtirò.

Mè cara soru, mè cara soru,

Mi vuliti arriscattari?"

"Mè cara soru, mè cara soru,

E quant' è lu ricàttitu tô?"

"Tri liuna, tri farcuna,

Quattru culonni chi d'oru su'."

"Nun pozzu perdiri tuttu ss' oru,

Quant' è megghiu ti perdi tu!"

"Marinaru, marina, marona,

Sammi a diri chi tempu fa,

S'è sciloccu o tramuntana

Nni lu mè spusu mi purtirò.

Miu caru spusu, miu caru spusu,

Mi vuliti arriscattari?"

"Mia cara spusa, mia cara spusa,

E quant' è lu ricàttitu tô?"

"Tri liuna, tri farcuna,

Quattru culonni chi d'oru su'."

"Megghiu perdiri tuttu ss' oru'

Basta chi 'un ti perdi tu."

E supra li tri ghiorna

E lu patri muríu.

"E lassatilu muriri

Tutta di russu m' hê vistiri."

E supra li tri ghiorna

E la matri muríu.

"E lassatila muriri

Tutta di giannu m' hê vistiri." 


\section{The Noble Sibilla}

Be it Sirocco or Tramontana,

To my sister I will go."

"O my sister, my dear sister!

Wilt thou not come and ransom me?"

"O my sister, my dear sister,

Tell me, what must thy ransom be?"

"Three gold lions, three gold falcons,

Four gold columns it must be."

"I cannot part with so much treasure,

How much better to part with thee!"

"O sailor, sailing, always sailing,

Tell me how does the sea-wind blow?

Be it Sirocco or Tramontana,

To my husband I will go."

"O my husband, my dear husband!

Wilt thou not come and ransom me?" "O my lady, my dear lady,

Tell me, what must thy ransom be?"

"Three gold lions, three gold falcons,

Four gold columns it must be."

"Better to part with all my treasure; Enough that I never part from thee."

And after three days were ended,

Her father was lying dead:

"Then let him die, and but little care I,

I will wear a gown all of red."

And after three days were ended,

Her mother was lying dead:

"Oh, let her die, and what care I?

I will dress all in yellow," she said. 
E supra li tri ghiorna

E lu frati moríu.

"E lassatilu muriri

Tutta di virdi m' hê vistiri."

E supra li tri ghiorna

E la soru muríu.

"E lassatila muriri

Tutta di biancu m' hê vistiri,

E si mori lu mè caru spusu

Di niuru arzolu m' hê vistiri."

Liebricht, Felix: "Ein Sicilisches Volkslied" in Zeitschrift für Deutsche Philologie (Halle, 1878), vol. ix., pp. 53-64.

\section{LO MARINER}

A la bora de la mar

-n' hi ha una donzella

Que 'n brodava un mocador

-qu' es per la reyna.

Quan ne fau á mig brodat

- li faltá seda;

Ven veni' un bergantí y diu:

- "Oh de la vela!

"Mariner, bon mariner

-que 'n portéu seda?"

"De quin color la voléu

-blanca ó bermella?"

"Bermelleta la vull jo

-que es millor seda."

"Entráu dintre de la nau

-triaréu d' ella." 


\section{The Noble Sibilla}

And after three days were ended,

Her brother was lying dead:

"Oh, let him die, and what care I?

I will dress all in green," she said.

And after three days were ended,

Her sister was lying dead:

"Oh, let her die, for what care I?

I will dress all in white," she said.

"But if my own dear love were dead,

I should wear blackest black," she said.

\section{THE SAILOR}

\section{(Catalan)}

At the margin of the sea

A maiden is sitting,

A kerchief embroidering,

For the queen fitting.

When the work is half done,

The silk it is failing:

She sees a splendid ship

Near the shore sailing.

"Sailor, with ship so fine,

Have you silk aboard her?"

"Wilt thou have white silk, or green?

With which dost thou embroider?"

"A light green is best of all, Other shades are duller."

"Come and enter my good ship;

Choose thine own color." 


\section{Folk-Ballads of Southern Europe}

Quan es dintre de la nau

-la nau pren vela.

Mariné 's posa á cantar

-cansons novellas.

Ab lo cant del mariner

- s' es dormideta;

$\mathrm{Ab}$ lo soroll de la mar

- ella 's desperta.

Quan ella s' ha despertat

- ja no 'n véu terra;

La nau es en alta mar,

-pèl mar navega.

"Mariner, bon mariner

- portáume á terra

Que á mi 'ls ayres de la mar'

-me 'n donan pena."

"Aixó si que no 'u faré

—qu'heu de ser meva."

"De tres germanas que som

— so la mes bella.

" $L$ ' una es casada ab un duch

-l'altra es princesa

$\mathrm{Y}$ jo pobreta de mi

-so marinera.

"L'una du faldillas d'or

-l'altra de seda,

$Y$ jo pobreta de mi

-'n duch de estamenya." 


\section{The Sailor}

So she enters, and the ship

Full-sail goes winging, And the sailor sings to her;

New songs he 's singing.

With the song the sailor sings

Sleep overtakes her,

But the surging of the sea

Soon it awakes her.

When she 's awake, she sees

The land disappearing, And the ship on the great waves

Out to sea steering.

"Mariner, good mariner, Home I 'd be sailing, With the salt air of the sea

My heart is ailing."

"Nay, nay, that cannot be, "Though thou despairest." "Oh, we were sisters three, I was the fairest.

"One wedded with a duke, One a prince married; Poor me, a sailor lass! Out to sea carried!

"One she wore robes of gold, One silk all shining; Poor me, in woollen stuff

I must go pining!" 


\section{Folk-Ballads of Southern Europe}

“No n' es d'estamenya, no,

-que n'es de seda

No sou marinera, no,

-que 'n seréu reyna,

"Que jo sò lo fill del rey

一de l'Inglaterra,

$\mathrm{Y}$ set anys que vaig pèl mar

- per vos donzella."

Briz y CANDI: Cansons de la Terra (Barcelona, 1866), vol. i., pp. I13-120.

\section{IL CORSARO}

(Ritornello: Sü la fiur de l'aqua-sü la fiur del mar.)

-O marinar de la marina, o cantè-me d'üna cansun.

-Muntè, bela, sü la mia barca, la cansun mi la canterò.-

Quand la bela l'è stáita an barca, bel marinar s'büta a cantè.

L'àn navigà pi d'sincsent mia, sempre cantand cula cansun.

Quand la cansun l'è stà fürnia, la bela $a$ cà n'in vol turnè.

- Sei già luntan pi d'sincsent mia, sei già luntan da vostra cà.

-Coza dirà la mama mia, che n'a sto tant a riturnè?

-Pensè pa pi a la vostra mama,

o pensè, bela, al marinar.-

S'a n'in ven la meza noiteja, n'in ven l'ura d'anđè dürmi. 
"No gown of stuff: you 'll wear

Gold and silk blended;

No sailor's lass art thou,

But a queen splendid.

“My father's England's king, A gold crown he 's wearing:

I 've sought thee seven years, On the sea faring."

\section{THE CORSAIR}

\section{(Piedmontese)}

(O flower of the water! Flower of the sea!)

"O sailor of the sea!

O sing a song to me!"

"Come up into my boat, my dear, And all my singing thou shalt hear."

She climbs into the sailor's barque;

He falls to singing like a lark.

Five hundred miles he sails along,

Singing always the same song.

When at last the singing dies,

For her home the maiden cries.

"We have sailed so long to-day,

Thy father's house is far away."

"Think of my dear mother's pain

If I do not come again."

"Think no longer of thy mother,

Think of me and of no other."

Soon comes on the midnight deep, And ' $t$ is time to go to sleep. 


\section{Folk-Ballads of Southern Europe}

-O dëspojè-ve, o dëscaussè-ve, cugei-ve sì cu'l marinar.

-I m'sun sulà-me tanto sćiassa, che 'l gital pōss pi dëssulè.

O marinar de la marina, o prëstè-me la vostra spà; Prëstè, galant, la vostra speja, che '1 gital pössa tajè.Quand la bela l'à avü la speja, an mes al cör a s'l'è piantà.

-O maledeta sia la speja, e cula man ch'a i l'à prēstà!

Ma s'i l'ái nen bazà-la viva,

a l'è morta la vöi bazè.-

Al'à pià-la per sue man bianche, ant ël mar a '1 l'à campè.

Nigra, C.: Canti Popolari del Piemonte (Torino, I888), No. $14 \mathrm{~A}$, pp. I06-I 10.

\section{IL MORO SARACINO}

Bel galant a si marida, si marida for d'pais.

L'à spuzà na fia giuvo, tanto giuvo e tant gentil.

Tanto giuvo cum'a l'era si savia pa gnianc vestì.

Al lùnes a l'à spuzà-la, al mártes la chita lì.

Bel galant l'è andà a la guerra, për set agn n'a turna pi;

E la povera Fiorensa

l'è restà sensa marì. 


\section{The Moor Saracen}

"Sweet, put by thy shoes and gown, And to sleep we will lie down."

"But this lace is bound so strong,

To undo it will take long.

$O$ brave sailor of the sea,

Will you lend your sword to me?

Lend me, gentle youth, your sword,

So that I may cut this cord."

His bright sword, the sailor lent it;

Deep into her heart she sent it.

"May the sword accursèd be, And the hand that gave it thee!

Living, I did not kiss thee, dear;

See how I kiss thy dead face here!"

He took her by her hands so fair;

Into the sea he cast her there.

(O flower of the water! Flower of the sea!)

\section{THE MOOR SARACEN}

\section{(Piedmontese)}

A gay youth goes to seek a wife in a country not his own;

She is young as she is pretty, not yet a woman grown,

So young she has not even learned to dress herself alone.

On Monday he has married her, on Tuesday he 's away,

The youth has gone off to the war for seven years to stay.

And so poor Fiorenza is left alone again. 


\section{Folk-Ballads of Southern Europe}

E da lì a i passa '1 Moro, ël gran Moro Sarazì.

L'à rubà bela Fiorensa, a l'à mnà-la a so pais.

A la fin de li set ani bel galant l'è rüvà lì.

Cun ün pè pica la porta:

"O Fiorensa, vnì a dürbì."

Sua mama da la finestra:

"Fiorensa l'è pa pi sì;

Fiorensa l'è stà rubeja dal gran Moro Sarazì."

"O tirè-me giû̀ mia speja, cula dël pügnal d'or fin.

Vöi andè serchè Fiorensa s'a n'a duvéissa mürì."

L'à trovà tre lavandere, ch'a lavavo so fardel.

“'Dì-me 'n po', vui lavandere, di chi è-lo cul castel?"

“Cul castel a 1'è dël Moro, dël gran Moro Sarazì;

E Fiorensa, bela Fiorensa, j'è set agn ch'a l'è là drin."

"Dì-me 'n po', vui lavandere, cum' farai-ne andè là drin?"

"Pozè cul vestì da pagi, vestirì da piligrin.

Andè ciamè la limozna sta séira o duman matin.

E Fiorensa, bela Fiorensa, ve darà dël pan e dël vin.'

Ël Moro da la finestra

da luntan l'à vist a vnì: 
When there comes riding by the Moor, the great Moor Saracen.

He has stolen Fiorenza and carried her to Spain.

When the seven years are finished, the youth comes home once more;

"O Fiorenza, it is I; come open me the door."

Cries his mother at the window: "You look for her in vain;

Fiorenza has been stolen by the great Moor of Spain."

"O mother, throw me down my sword, with the hilt of gold so fine;

Though I should die upon the road, I will find this love of mine."

He has found three washerwomen, washing beside the way:

"Now whose is that great castle, good women, can you say?"

"It is the castle of the Moor, the great Moor Saracen: Fiorenza's there these seven years, and goes not home again."

"Tell me, good washerwomen, how could one enter there?"

"You must put your fine clothing off, and like a pilgrim fare;

This evening or to-morrow, go beg for alms," they said,

"And pretty Fiorenza will give you wine and bread."

The Moor is at the window, and far away looks he: 


\section{$5^{0}$ Folk-Ballads of Southern Europe}

"O guardè, bela Fiorensa, 'n piligrin dël vost pais."

"D'me pais a pöl pa esse, pöl pa esse d'me pais.

J'uzelin ch'a vulo an'ária pölo pa vnì fin a sì.

S'a n'in füss la rundanina, ch'a gira tüt quant ël dì."

"Fè limozna, 'n po' d'limozna a sto póvër piligrin!" An fazend-je la limozna a j'à vist so anel al dì. E Fiorensa 1'à conossû̀-lo ch'a l'era so prim marì. S'a n'in va a la scüdaria, munta an sela al caval gris.

"Stè-me alegre, mie creade, mi m'n'a turno al me pais." Ë1 Moro da la finestra s'büta a piánzer e gemì: "Avei-la mantnû set ani sensa gnianc tuchè-je 'n dì!"

Nigra, C.: Cantı Popolari del Premonte (Torino, 1888), No.40 A, pp. $213-256$.

\section{CRIBETO}

Cribeto, l'an casado, Hillo de Cormesi.

Ero n'es tant petito,

Nou se sab pas besti.

L'amour la teng, l'amour qui nous la teng, Boudrio la teni. 


\section{Cribete}

"See the pilgrim, Fiorenza, who comes from your country."

"From my country he is not, no, not from my country! The birds in the air flying, fly not so far away,

Except it were the swallow that wheels about all day."

"Give alms to a poor pilgrim, who begs from land to land."

But she has seen, in giving, the ring upon his hand, And Fiorenza knows him for her first love, indeed. He has hurried to the stables and mounted a gray steed.

"Oh, wish me well, my maidens, I go to my country!" But the Moor up at the window is sobbing bitterly:

"Seven years have I maintained her, and she would none of me!"

\section{CRIBETE}

(Gascon)

Cribete, they have married her, Cormesin's daughter fair;

She is still too little

To dress her own bright hair.

Love holds her close; The love that may not hold her Longs to enfold her. 


\section{Folk-Ballads of Southern Europe}

Soun marit ba a la guerro,

Per la dècha grandi.

Quant la guerro es finido,

Que tourno au soun pais.

S'en ba tusta a la porto.

- "Cribeto, sai oubri."

Sa mai, touto plourouso:

- "Cribeto n'es aci.

Lou rèi Maurou l'a preso,

Miado en soun pais."

- "Dounatz-me la capo roujo,

Lou bastoun de sapin."

Ba demanda l'aumoino,

Dens lou pais Mauri.

Dou balcoun dou rèi Maurou

Cribeto que l'a bist.

Pintuo cabellino,

Dab un pintou d'or fin.

- "Hè caritat, señora,

Au praube pelegrin."

- "Nau podi pas, señor.

Jou nou soui pas d'aci."

Rèi Maurou l'escoutauo,

Dou houn dou gran jardin.

- "Hè caritat, señora,

Au praube pelegrin.

Se n'ès ma henno adaro,

Seras douman maitin." 


\section{Cribete}

Her husband rides away to war,

Until she shall be grown;

But when the war is over

He comes back to his own.

He stands a-knocking at the door:

"Open to me, my dear!"

His mother speaks, all weeping:

"Cribete is not here.

"The Moorish king came riding; He stole Cribete and fled."

"Give me a staff of willow, And a cloak of red."

And he has gone a-begging,

Clad like a poor pilgrim;

Till from her balcony Cribete

Leans and looks down on him.

She combs her hair with a fine gold comb,

In the palace of the Moor;

"Give charity, señora,

To a pilgrim poor."

"I have no money, señor;

My home is far from here."

And the Moorish king he listens

In the great garden, near.

"Give charity, señora, To a pilgrim all forlorn;

If thou art not my wife to-night, Thou wilt be to-morrow morn." 


\section{Folk-Ballads of Southern Europe}

—“Bèi a l'escuderio:

Preng lou millou roussin.

Rèi Maurou lous acasso:

—"Cribeto, sai aci."

$\left.\begin{array}{l}\text { Quant soun au pount d'Obiedo, } \\ \text { Lou pount beng a parti. }\end{array}\right\}$ (bis)

- "Bierge te l'aui preso,

E bierge l'as aci."

L'amour la teng, l'amour qui nou la teng,
Boudrio la teni.

BladE, J-F.: Poésies Populaires de la Gascogne (Paris, 1881-2), vol. ii., pp. 44-49.

\section{EL CONDE SOL}

Grandes guerras se publican

Entre España y Portugal:

Pena de la vida tiene

Quien no se quiera embarcar.

Al conde Sol le nombran

Por capitan general;

Del rey se fué á despedir,

De su esposa otro que tal.

La condesa que era niña,

Todo se le va en llorar.

"Dime, conde, cuántos años

Tienes de echar por allá?"

"Si á los seis años no vuelvo,

Condesa, os podeis casar." 


\section{Count Sol}

He has robbed the royal stables;

The steed flies like the wind:

"Come back, come back to me, Cribete!"

Cries the Moorish king behind.

The bridge of Oviedo

Breaks ere their horse has passed:

"Maiden I took her from thee,

Maiden she 's thine at last."

Love holds her close;

The love that may not hold her

Longs to enfold her.

\section{COUNT SOL}

\section{(Castilian)}

A great war they are declaring Between Spain and Portugal; Any man's life would be forfeit

Who refused that battle-call; And the brave Count Sol is chosen

To be Captain General.

Of his king and of his lady

He has sadly taken leave;

Now the countess was but little;

She could only grieve and grieve.

"Tell me, my Lord Count, how many

Years before you come?" she said.

"In six years, if I still linger,

Little Countess, you may wed." 


\section{Folk-Ballads of Southern Europe}

Pasan los seis, y los ocho,

Pasan diez y pasan mas,

$\mathrm{Y}$ el conde Sol no tornaba

$\mathrm{Ni}$ nuevas suyas fué á dar.

Estando en su estancia sola,

Fuéla el padre á visitar:

"Qué tienes, hija querida,

Que no cesas de llorar?"

"Padre de toda mi alma,

Por la santa Trinidad,

Que me querais dar licencia

Para al conde ir á encontrar."

"Mi licencia teneis, hija,

Haced vuestra voluntad."

La condesa al otro dia

El conde se fué a buscar, Triste por Italia y Francia,

Por la tierra y por la mar.

Ya estaba desesperada,

Ya se torna para acá,

Cuando gran vacada un dia

Devisó allá en un pinar.

"Vaquerito, vaquerito,

Por la santa Trinidad,

Que me niegues la mentira

$Y$ me digas la verdad:

De quién son estas vaquitas

Que en estos montes están?"

"Del conde Sol son, señora,

Que manda en este lugar." 


\section{Count Sol}

And the years pass, two years, four years,

Six and eight, ten years and more, But the Count Sol still is absent,

And no tidings reach his door.

Comes the father of the countess,

Where she keeps her watch alone:

"Little girl, what is your trouble,

That your tears are never done?"

"Father of my heart, dear father, By the Holy Trinity,

Give me leave to make a journey,

To find where Count Sol may be!"

"Go your way, my little daughter, You shall not have 'no' from me."

So the countess leaves next morning, Journeys over land and sea;

Always for her lover seeking,

Sad, through France and Italy.

On a day she was despairing, Ready to turn home at last, When she saw a great herd fecding In a pine grove where she passed.

"Little herd-boy, little herd-boy, By the Holy Trinity,

Do not tell me any lies now, Tell the simple truth to me;

"Tell me whose are all the cattle I see feeding in this place."

"They are the Count Sol's, señora, He has sent them here to graze." 


\section{Folk-Ballads of Southern Europe}

"Y de quién son esos trigos

Que cerca están de segar?"

"Señora, del mismo conde,

Porque los hizo sembrar."

"Y de quién tantas ovejas

Que á corderos dan mamar?"

"Señora, del conde Sol,

Porque los hizo criar."

"De quién, dime, esos jardines

Y ese palacio real?"

"Son del mismo caballero;

Porque alli suele habitar."

"De quién, de quién los caballos

Que se oyen relinchar?"

"Del conde Sol, que suele

Sobre ellos ir á cazar."

"Y quién es aquella dama

Que un hombre abrazando está?"

"La desposada señora,

Con que el conde va á casar."

"Vaquerito, vaquerito,

Por la santa Soledad,

Toma mi ropa di seda,

$\mathrm{Y}$ vísteme tu sayal,

Que ya hallé lo que buscaba,

No lo quiero, no, dejar;

Agárrame de la mano

Y á su puerta me pondrás,

Que á pedirle voy limosna,

Por Dios, si la quiere dar." 


\section{Count Sol}

"Tell me whose are all those wheat fields Almost ready to be mown."

"They are the same count's, my lady, By his servants they were sown."

"And those flocks of ewes, pray tell me, That are suckling young ones there?"

"Those are the Count Sol's, señora, That his shepherds have in care."

"Whose are those great gardens, tell me, And that royal palace grand?"

"Those are the same knight's, señora, Where he lives on his own land."

"Tell me whose are all the horses, Neighing round about the place." "Those are the count's hunting horses That he uses for the chase."

"Tell me then who is the lady In that man's embrace," she said.

"That is the count's bride, señora, They are just about to wed."

"Little herd-boy, little herd-boy, By the Holy Unity,

Take this gown of silk I ' $m$ wearing, Give thy suit of serge to me.

"For I find what I am secking, And I will no further go.

Take me by the hand and lead me Yonder to that portico;

There for alms I '1l stand a-begging; They will give me gold, I know." 


\section{Folk-Ballads of Southern Europe}

Desque estuvo la condesa

Del palacio en el umbral,

Una limosnica pide

Que se la dén por piedad,

$Y$ fué tanta su ventura,

Aun mas que era de esperar,

Que la limosna demanda

Y el conde se la fué á dar.

"De dónde eres, peregrina?"

"Soy de España natural."

"Cómo llegastes aqui?"

"Vine mi esposo á buscar,

Por tierra pisando abrojos,

Pasando riesgos en mar,

$Y$ cuando le hallé, señor,

Supe que se iba á casar,

Supe que olvidó á su esposa,

$\mathrm{Su}$ esposa que fué leal,

$\mathrm{Su}$ esposa que por buscalle

Cuerpo y alma fué á arriesgar."

"Romerica, romerica,

Calledes, no digas tal,

Que eres el diablo sin duda

Que me vienes á tentar!"

"No soy el diablo, buen conde,

$\mathrm{Ni}$ yo te quiero enojar;

Soy tu mujer verdadera,

$\mathrm{Y}$ así te vine á buscar." 
When the countess reached the palace,

She stood in the portico,

And begged alms of any passer

Who, she thought, might pity show.

There befell her great good fortune,

Beyond all her hope at last;

As she stood there begging money,

'T was the count himself that passed.

"Now whence do you come, fair pilgrim?"

"I am Spanish born," said she.

"And how did you reach my palace?"

"By the dangers of the sea,

"And by land where ways were thorny,

I have sought my love," she said;

"But when I had found him, señor,

He was just about to wed.

"His own bride he had forgotten, His bride, loyal to her troth;

His bride, who, that she might seek him,

Ventured soul and body both."

"Pilgrim, pilgrim, pretty pilgrim, Do not say such things!" cried he;

"Without doubt you are the devil, And are come a-tempting me!"

"My Lord Count, I am no devil, And I would not give you pain.

I am your own loyal lady,

Come to seek you out of Spain." 


\section{Folk-Ballads of Southern Europe}

E1 conde cuando esto oyera,

Sin un punto mas tardar,

Un caballo muy lijero

Ha mandado aparejar,

Con cascabeles de plata,

Guarnido todo el pretal;

Con los estribos de oro,

Las espuela otro tal,

$Y$ cabalgando de un salto,

Á su esposa fué á tomar,

Que de alegría y contento

No cesaba de llorar.

Corriendo iba, corriendo,

Corriendo va sin parar,

Hasta que llegó al castillo

Donde es señor natural.

Quedádose ha la novia

Vestidica y sin casar,

Que quien de lo ajeno viste,

Desnudo suele quedar.

DuRan, Agustin: Romancero General (Madrid, 1851), vol. i., pp. 180 seq. Also, Wolf y Hofmann: Primavera (Berlin, 1856), vol. ii., pp. 48-52.

\section{A PEREGRINA}

Peregrina, a peregrina

Andava a peregrinar

Em cata de um cavalleiro

Que the fugiu, mal pezar!

A um castello torreado

Pela tarde foi parar:

Signaes certos, que trazia

Do castello, foi achar. 


\section{The Pilgírim}

The Count Sol when he had heard this

Not a minute would he wait, But his swiftest horse he called for

To be ready at the gate.

All about the horse's bridle

Tinkled many a silver bell;

And the rein with gold was shining,

And the spurs were gold as well.

The count vaulted to the saddle,

And his wife behind was set;

So glad was she and contented

That her eyes with tears were wet.

They went running, always running,

Never once did they dismount,

Till in Spain they reached the castle

That belonged to my Lord Count.

The new bride was left unmarried,

Lonely in her wedding-dress;

One who steals another's treasure

Shall be left in nakedness.

\section{THE PILGRIM}

(Portuguese)

A fair lady like a pilgrim, Like a pilgrim see her pass, Seeking long time for her lover, Who deserted her, alas!

To a battlemented castle Just at evening she draws near;

Certain signs about the castle Tell her heart that he is here. 


\section{Folk-Ballads of Southern Europe}

"Mora aqui o cavalleiro?

Aqui deve de morar."

Respondêra-lhe uma dona

Discreta no seu fallar:

"O cavalleiro está fóra,

Mas não deve de tardar.

Se tem pressa a peregrina,

Ja lh'o mandarei chamar."

Palavras não eram dittas,

O cavalleiro a chegar:

"Que fazeis porqui, senhora,

Quem vos trouxe a este logar?"

"O amor de um cavalleiro

Por aqui me faz andar.

Prometteu de voltar cedo,

Nunca mais o vi tornar;

Deixei meu pae, minha casa,

Corri por terra e por mar

Em busca do cavalleiro,

Sem nunca o podêr achar!"

"Negro fadairo, senhora,

Que tarde vos fez chegar!

Eu de vosso pae fugia

Que me queria mattar;

Corri terras, passei máres,

A este castello vim dar.

Antes que fôsse anno e dia

(Vós me fizestes jurar)

Com outra dama ou donzella

Não me havia desposar. 
"Tell me, pray, whose is this dwclling?

It is here the knight should dwell."

Said the lady of the castle

(Prudently she spoke and well):

"The master of the house is absent,

But 't is time that he should come;

If time presses for the pilgrim

I will send to call him home."

Scarcely had the words been spoken,

When came in the chevalier.

"What has brought you here, señora?

Whom do you come seeking here?"

"It is love of my own lover

That has brought me to your door.

He had promised to come quickly,

But he came to me no more.

I have left my house, my father,

Journeyed over land and sea;

Everywhere I seek my lover,

Yet know not where he may be."

"Oh, 't is evil luck, señora,

That has brought you here so late!

I was forced to fly your father;

He would kill me in his hate.

Over sea and land I traveled

Till I reached this castle gate.

You had made me swear, señora,

For a year and day to wait,

And with neither dame nor damsel

All that time to married bc; 


\section{Folk-Ballads of Southern Europe}

Anno e dia eram passados

Sem de vós ouvir fallar,

Co'a dona d'esse castello

Eu hontem me fui casar." . . .

Palavras não eram dittas,

A peregrina a expirar.

"Ai penas de minha vida,

Ai vida de meu penar!

Que farei d'esta lindeza

Que em meus braços vem finar?"

Do alto de sua tôrre

A dama estava a raivar:

"Levá-la d'ahi, cavalleiro,

E que a deitem ao mar."

"Tal não farei eu, senhora,

Que ella é de sangue real.

E amou com tanto extremo

A quem the foi desleal.

Oh! quem não sabe ser firme,

Melhor fôra não amar."

Palavras não eram dittas

O cavalleiro a expirar.

Manda a dona do castello

Que os vão logo interrar

Em duas covas bem fundas

Alli junto á beira-mar.

Na campa do cavalleiro

Nasce um triste pinheiral,

E na campa da princeza

Um saudoso canavial. 


\section{The Pilgírim}

But the year and day were ended And no word had come to me:

With the lady of this castle

Yestermorning I was wed."

Now the words were scarcely spoken

When the pilgrim sank down dead.

"Oh, alas! the pain of living!

Oh, what life of pain have I!

What should I do with this beauty,

Come back to my arms to die?"

Now the lady from her tower

Watched in wrath and jealousy:

"Take her up from there, my husband,

Bid them cast her in the sea."

"That I never will do, lady,

For by blood she is a queen;

As her love to me was faithful,

So have I disloyal been.

He who knows not to be faithful,

Better never love at all."

Now the words were scarcely spoken,

When they saw the lover fall.

Then the lady of the castle

Bids that they should buried be

In two new-made graves, digged deeply

By the margin of the sea.

From the grave of the dead lover

There grew up a sad pine grove;

And a bed of wistful reeds grew

From the grave of his dead love. 


\section{Folk-Ballads of Southern Europe}

Manda a dona do castello

Todas as canas cortar;

Mas as canas das raizes

Tornavam a rebentar:

$\mathrm{E}$ á noite a castellana

As ouvia suspirar.

Almeida-Garrett, V. DE: Romanceiro (Lisboa, 1875), vol. iii., pp. $3^{\mathrm{I}-38}$.

\section{ERO E LEANDRO}

Chi la völ sentì-la cantè

d'ün amante e d'üna bela?

So pare a la völ maridè,

dè-je ün omo a sua fantè.

La bella a i dis ch'a '1 lo völ nen,

ch'a j'è bin pi car so car Leandro.

$\mathrm{E}$ so pare a l'è sautà an fürur,

l'à fà-la bütè an fund d'üna tur.

S'a na ven sü l'induman,

gentil galant a va truvè-la.

-Gentil galant, vui avì bun cor

de vnì-me a vëđe al fund d'custa tur.

-I'avniria 'n po' pi sovens, s'a füssa nen dël re vost pare.

-Gentil galan, s'vui féisse lo-lì, faria bütè i flambò për insegna;

Quand i flambò saran alimè, vui farì forsa për intrè.-

S'a na ven sü l'induman, gentil galant a va truvè-la, 


\section{Hero and Leander}

Now the lady of the castle

Sends to cut the tall reeds low,

But the more the mowers reap them,

From the roots they faster grow;

In her tower the lady hears them

Sighing when the night winds blow.

\section{HERO AND LEANDER}

(Piedmontese)

Who will hear the song sung over, Of a beauty and her lover?

She will not heed her father's voice, And take a husband of his choice.

All in vain does he command her; Too dear is her own dear Leander.

In great rage, that very hour, Her father shuts her in a tower.

When the sun rose the next day, The noble youth came by that way.

"O noble youth, your heart is brave, To come and seek for me and save.

"Now, if to save my life you came, Wait till you see the torches flame.

"When I have given you that sign, Come and break down these doors of mine."

The evening of the second day The noble youth came by that way. 


\section{Folk-Ballads of Southern Europe}

A s'è bütà-se a l'umbra d'üna rul,

a l'à đürmì la nóit e 'l giurn.

Bel galant s'e dazviè,

a l'à vist ch'la tur l'era già 'n fiame;

Quand ch'a l'à vist la tur a brüzè,

giù da la mar a s'è tampè.

La bela ch'a l'era là,

ch'a guardava so car Leandro,

Quand a '1 l'a vist ant ël mar a niè,

giù da la tur a s'è tampè.

Nigra, C.: Canti Popolari del Piemonte (Torino, 1888), No. 7 A, pp. 68-70.

\section{LA PROVA}

"O cantè, cantè, fieta, finchè sei da maridà."

"Mi vöi pa cantè nè ride, che 'l me cör l'è passionà.

Lo me amur l'è andà a la guera; da set agn l'è pi turnà.

Se savéissa 'n po' la strada, l'andaria a riscuntrà."

Quand l'è stáita a meza strada, ün bel giuvo a l'à scuntrà.

"O dizì-me vui, bel giuvo, j'éi-vo vist me annamurà?" 
He threw him down beneath an oak;

'T was the next night when he awoke.

The gallant youth awoke in shame:

He saw the tower all aflame.

And when he saw it burning, he Threw himself into the sea.

The beauty watched from far away The place where her Leander lay.

When in the sea she saw him drown, From the high tower she cast her down.

\section{THE TEST}

\section{(Piedmontese)}

"Oh, sing, sing, pretty maiden, Until your wedding-day!"

"Can I sing or smile with a broken heart, And my love so far away?

"My sweetheart went away to war, 'T was seven long years ago!

Oh, I would like to follow him, But the way I do not know."

As she set out upon the road,

She met with a fair youth:

"Pray, have you seen my own sweetheart?

O brave lad, tell me truth." 


\section{Folk-Ballads of Southern Europe}

"Sì che furse i l'ái vedù-lo, ma i '1 l'ái pa riconossî́.

$\mathrm{O}$ dizì-me vui, fieta, cum a l'er-lo mai vestù?"

"L'era tüt vestù di rosso cun el capelin bordà,

Cun la speja a la sintüra

e la sćirpa ricamà."

"O sì, sì ch'i l'ái vedû̉-lo, l'era bin acumpagnà;

Cun sinquanta torce avische lo portavo a suterà."

La bela l'è cascà an tera, cascà an tera dal dolur. "O stè sü, stè sü, fieta, che sun mi '1 vost prim amur!"

Nigra, C.: Canti Popolari del Piemonte (Torino, 1888), No. 5+ A, pp. 314-315.

\section{PIERRE DE GRENOBLE}

Pierre s'en va-t-à arméie, Pour bien demeurer,

N'a laissé sa mie à Grenoble, Qui fait que pleurer.

Pierre n'at envoyé une lettre De ses amitiés,

La belle n'at envoyé une autre, Qui est toute de pleurs. 


\section{Pierre of Grenoble}

"It may be I have seen him, How should I know him there?

$\mathrm{Oh}$, tell me, pretty maiden,

What did your sweetheart wear?"

"He wore a cap with a band of gold;

He wore a coat of red;

He had a sword girt at his waist

With a scarf embroiderèd."

"Oh, yes, yes, I have seen him;

He had an escort brave:

With fifty torches burning bright

They bore him to his grave."

The maiden fell down to the earth, She fell to earth for pain.

"Oh, rise, rise, dear, I am your love,

Your first love come again!"

\section{PIERRE OF GRENOBLE}

(French)

Pierre and all his company

Are ordered far away;

His sweetheart, left in Grenoble town,

Weeps the livelong day.

Pierre has sent a letter sweet, All full of lover's fears; And she has written one to him, Made of grief and tears. 


\section{Folk-Ballads of Southern Europe}

Pierre n'a pas vu cette lettre,

Ne fait que pleurer,

S'en va trouver son capitaine:

"Donnez mon congé."

"Pour ton congé, je te le donne, Tu retourneras."

"Oh! si ma mie est en vie, Je l'épouserai,

Si ma mie en est morte,

Je retournerai."

Il nen fut pas sur ces montagnes,

Dessus ces rochers,

Entend les cloches de Grenoble

Qui font que sonner.

Pierre n'a mis le genou en terre, Son chapeau à la main,

Priant Dieu, la Vierge Marie

De sa mie voir.

Il nen fut pas dedans Grenoble, Sa mie n'a trouvé,

Accompagné de trente dames,

De vingt cavaliers.

"Vous autres qui portez ma mie, Laissez-moi la voir.

Découvrez-lui son blanc visage, Car je veux la voir." 


\section{Pierre of Grenoble}

Pierre can scarcely read the page

It sets him weeping so;

But he has sought his captain out:

"Give me leave to go."

"I give you leave all willingly,

But come again," he said.

"Oh, if my true love is alive,

We surely will be wed;

But I shall come to you again,

If my true love be dead."

Pierre has climbed the mountain path

Where the rocks steepest are;

He hears the bells of Grenoble town

Tolling from afar.

He stands and listens hat in hand;

He drops upon his knee, Praying to God and Mary mild

His true love he may see.

Scarce has he entered Grenoble town

When his true love appears,

Beside her thirty gentle dames

And twenty cavaliers.

"O you who carry my true love,

I pray you give me place!

Uncover me the bier," he cries;

"Let me see her face." 


\section{Folk-Ballads of Southern Europe}

Pierre n'a tiré son espéie,

Le drap n'a percé,

Quand il a vu son blanc visage,

Il n'a renversé;

Quand il a vu son blanc visage,

Il n'a trepassé.

Que diront les gens de Grenoble

De ces amoureux?

Diront: "L'un pour l'amour de l'autre,

Ils sont morts tous deux."

Smith, Victor: Vielles Chansons du Velay et du Forez, Romania (Paris, 1878), vol. vii., pp. $83-84$.

\section{LA SPOSA MORTA}

Gentil galant s'l'áute muntagne

l'à sentì le cioche sunè:

-A sarà-lo mia spuzetta,

che a la porto a suterè?-

Gentil galant a l'è andà a caza,

l'à truvà la porta sarà:

-O vezine, mie vezine,

mia spuzetta duv è-la anda?

- Vostra spuzetta l'è andà a la ceza,

a la ceza ben cumpagnà,

Cun sinquanta e due torce

a faziu la lüminà.-

Gentil galant va a la ceza,

a l'à dumandà-la a áuta vus,

A áuta vus a l'à dumandà-la;

a bassa vus a j'à rispus: 


\section{The Dead Bride}

Pierre has drawn his shining sword

And pierced the funeral pall;

He looks upon her snow-white face

To stagger back and fall;

He looks upon her snow-white face

And dies before them all.

All the good folk of Grenoble town,

What is this they say?

"These were true lovers and for love

Both lie dead to-day."

\section{THE DEAD BRIDE}

\section{(Piedmontese)}

A gallant youth on the high mountains,

Far off hears the church bells ring;

"For my bride they must be sounding,

Carried to her burying."

The gallant youth, returning homeward,

Finds his own door bolted fast:

"O my neighbors, my dear neighbors,

Who has seen my sweet wife last?"

"Your sweet bride, so fair attended,

To the church has gone to-day;

Two and fifty flaming torches

Lighted her along the way."

To the church has gone the gallant,

Loud he calls upon his dead:

With loud voice he called unto her,

With soft voice she answerèd. 


\section{Folk-Ballads of Southern Europe}

-Cul anlin ch'i l'avei spuzà-me, guardè-lo sì ch'l'ái ant ël dil.

$O$ piè-lo, spuzè-ne n'áutra, dì-e ch'a prega Dio për mi.

Dì-e ch'a 's cata üna curunina e ch'a la dia tre volte al dì;

Due volte sarà për chila, üna volta sarà për mi.-

Nigra, C.: Canti Popolari del Piemonte (Torino, I888), No. 17 A, pp. 120-124.

\section{LA SPOSA MORTA}

L'uzelin a l'era sü la rama, sü la rama ch'a godeva '1 sul, A risguardava Catalinota,

Catalinota, ch'a móir d'amur.

Gentil galant sü l'áute muntagne

a l'à sentì le cioche sunè:

- Sarà-lo '1 segn dla Catalinota, ch'a l'è morta da maridè?Quand l'è stáit su cule coline a l'à vedü le torce lüzì:

- Sarà-lo furse la lüminária ch'a l'acumpagna a sepelì?

$O$ portandin che porte la bela, o ripozei-ve e pozei-la 'n po'!

Pozei-la sì sü la violëta, che ancur na volta la bazerò. 


\section{Catalinòta}

"Thine own ring as when we wedded, Still upon my finger, see;

Take it, wed with it another;

Bid her pray to God for me.

"Tell her that she must be saying Every day her rosary,

Twice a day for herself praying, Praying the third time for me."

\section{CATALINÒTA}

\section{(Piedmontese)}

A little bird high on the branches swinging, High up and happy in the sun above,

Is looking down upon Catalinòta, Catalinòta who lies dead of love.

A gallant youth far off upon the mountains Hears the chimes ring and wonders: "Can it be That the bells toll for my Catalinòta, Catalinòta, dead for love of me?"

When he is standing high up on the hill-top,

Down there below he sees the torches' light:

"If that should be the torches in procession, A-carrying her to burial to-night!

"O bearers, bearers, carrying my beauty, Halt for a little and set down the bier; Set it down softly there upon the violets, And for the last time let me kiss my dear. 


\section{Folk-Ballads of Southern Europe}

O parla, parla, buchëta morta,

o parla, parla, buchëta d'or!

$O$ dì-me sul che na parolëta,

o à-me sul che 'n bazin d'amur.

-O cume mai volì-ve che v' parla, e che vi daga 'n bazin d'amur?

Mia buca morta l'à odur di terra, ch'a l'era, viva, di roze e fiur.

Vostr'anelin che vui i m'éi dà-me, guardè-lo sì ch'a l'è 'nt ël me dì;

Piè-lo püra e dè-lo a ün' áutra,

e tüti dui pregherei për mi.-

Nigra, C.: Canti Popolari del Piemonte (Torino, 1888), No. I7 D, pp. I20-I 24 .

\section{DANZE E FUNERALI}

Sun levà-me la matin (Povero a mor!)

la matin ben da bunura. (Rosignolin d'amor!)

Sun andáit ant ël giardin

a cōjì la bianca fiura.

I l'ái fáit dui buchetin,

ün për mi, l'áut për mia sgnura.

-Piè, vui bela, cust massolin;

custa a l'è la dispartia,

La dispartia tra mi e vui,

me pare völ nen ch'i v' pia;

A völ nen ch' i spuza vui,

völ ch' i spuza n'áutra fia;

L'è pa tan bela cum' vui,

ma s'a l'è ün po' pi rica. 


\section{Bridal Dance and Funeral}

"Speak, oh, speak to me, dear little dead mouth!

Speak to me, speak, dear little mouth of gold!

Say to me just one little word of loving,

Give me one little love-kiss like the old."

"How can I ever, how can I speak to you?

How can I give you a kiss of love and death?

My little mouth smells of the earth in dying,

That when I lived was like the roses' breath.

"The little ring that long ago you gave me,

I wear it still upon my finger, see!

Take it away and give it to another;

And both of you say prayers to God for me."

\section{BRIDAL DANCE AND FUNERAL}

\section{(Piedmontese)}

I was up in the morning early Alas, poor Love!

$\mathrm{Up}_{\mathrm{p}}$ in the morning very early Nightingales sing of love.

I went down into the garden, Gathering white flowers there;

For myself I made a nosegay,

And one for my lady fair.

"Take, my beauty, take these flowers, For our parting they must be,

Our last parting, for my father

Will not let you marry me;

"Will not let us two be married;

Bids me wed another bride;

One who has not half your beauty, But more riches and more pride. 


\section{Folk-Ballads of Southern Europe}

E quand ben ve spuzi pa,

i v'invito a le mie nosse.

-A le nosse vöi pa venì,

venirò a le vostre danse.

Vestirò di satin bianc,

o pür di scarlata russa,

$O$ püra di brocà d'or,

l'è për tant che mi conusse.-

La bela arivà sül bal,

a l'àn suna-je na dansa.

La bela l'à fáit ün gir,

l'è cascà 'n tera morta.

Bel galant l'à fáit dui gir,

l’è cascà da l'áutra banda.

Nigra, C.: Canti Popolari del Piemonte (Torino, 1888), No. $20 \mathrm{~A}$, pp. $\mathrm{I} 39-\mathrm{I} 4 \mathrm{I}$.

\section{FIOR DI TOMBA}

Di là da cui boscage

$\mathrm{Na}$ bela fia a j'è;

So pare e sua mare

La völo maridè.

A völo đè-i-la a ün prinsi

Fiöl d'imperadur.

"Mi vöi nè re nè prinsi

Fiöl d'imperadur;

Déi-me cul giuvinoto

Ch'a j'è 'n cula pērzun."

"O fia dla mia fia,

L'è pà 'n partì da ti;

Duman a úndes ure

A lo faran mürì." 
"On the day when I am married, Come and wish me happy chance."

"I will come, not to your wedding, Only to your bridal dance.

"I will dress me in white satin; No, in gown of scarlet fine; No, in cloth of gold, brocaded, You may know me by that sign."

The fair maid came as the music Played the first dance for the bride; The fair maiden danced one circle, Fell upon the ground and died; The brave lover danced two circles, And fell dying at her side.

\section{FLOWERS FROM THE GRAVE (Piedmontese)}

There lives a pretty maiden,

Down there beyond the wood;

Her father and her mother

They would make her a marriage good.

They would marry her to a noble prince,

An emperor's son and heir.

"I do not want a king nor prince,

Nor emperor's son and heir;

But give to me the gallant youth

Who is in the prison there."

"O daughter, $\mathrm{O}$ my daughter!

You cannot be his wife;

To-morrow at eleven o'clock,

They will surely take his life." 


\section{Folk-Ballads of Southern Europe}

"S'a fan mürì cul giuvo,

Ch'a m' fasso mürì mi;

Ch'a m' fasso fè na tumba

Ch'a i sia d' post për tri,

Ch'a i stago pare e mare,

'L me amur an brass a mi.

"An sima a cula tumba

Piantran dle röze e fiur;

Tüta la gent ch'a i passa

A sentiran l'odur;

Diran: 'J'è mort la bela,

L'è morta për l'amur!'”

Nigra, C.: Canti Popolari del Piemonte (Torino, 1888), No. 19, pp. I29-1 39.

\section{LE DUE TOMBE}

Ant ël bosco di Cazale

bela fia va a cantà.

- O cantè, cantè, fieta,

fin che sei da marida! -

Bel galant va da so pare:-

-Vostra fia m'la völi dà?-

So pare j'à fáit risposta,

ch'a i la vuria nen dà.

Bel galant l'è vnü malavi

e la bela a na stà mal.

Bel galant viv a panade

e la bela a pan gratà.

Bel galant l'è mort a l'alba

e la bela al sul levà.

Bel galant l'àn sutrà an ceza

e la bela sül piassal. 


\section{The Two Graves}

"Oh, if they murder that young man, Then let them murder me!

And let them make a grave for us,

A grave with places three,

One place for father and one for mother,

And but one for my love and me.

And at the grave's head let them plant

A blossoming rose tree.

"All the people who pass by,

The roses they will smell;

They will say: 'She died, the beauty,

Because she loved too well.,"

\section{THE TWO GRAVES}

(Piedmontese)

Through the forest of Casal

A fair maiden singing goes;

"Sing, sing on, my pretty maiden,

Till you 're married, then who knows?"

A gay youth goes to her father:

"Your fair daughter to me give."

But the father makes him answer:

"Never, never! as I live!"

The gay lover he falls ailing,

And the girl takes to her bed;

The gay lover lives on porridge,

And the maiden on dry bread.

The gay youth dies in the dawning,

And the maiden at sunrise;

She is buried in the churchyard,

And within the church he lies. 


\section{Folk-Ballads of Southern Europe}

Sü la tumba d'bel galant

j'è nassü 'n pumin granà,

Sü la tumba de la bela

j'è nassü na mandolà.

Tanto bin cum a cressio,

fazio umbra a tre sità,

Alessánđria e Valensa

e la pi bela Cazal.

Nigra, C.: Canti Popolari del Piemonte (Torino, r888), No. 18 A, pp. 125-128.

\section{LOU COUNTE ARNAUD}

Lou counte Arnaud, lou chibaliè,

A la guerre s'en est allé.

-Counte Arnaud, aro que t'en bas,

Digo-nous dounc quant tourneras.

-Enta Sent-Joan jou tournerèi;

E mort ou biu aci serèi.-

La Sent-Joan beng a arriba:

Lou counte Arnaud beng a manqua.

La bieillo mounto au soulè,

Bese lou counte Arnaud arriver.

Ero n'a bist tres cabaliès.

Lou counte Arnaud qu'es lou dou mièi.

-Jou lou counechi, au chibau, Qu'Arnaud es triste e bien malau.

Jou lou counechi, au bridoun, Qu'Arnaud beng triste en sa maisoun. 


\section{Count Arnaud}

From the tomb of the fair maiden

There springs up an almond tree;

From the tomb of the brave lover,

A pomegranate fair to see.

They have grown so tall and stately,

On three towns their shadows fall,

Alessandria and Valenza,

And the beautiful Casal.

\section{COUNT ARNAUD}

(Gascon)

The Count Arnaud! the Count Arnaud!

To the wars now he will go.

"Tell us, then, brave chevalier, When will you again be here?"

"For Saint John's feast," Count Arnaud said, "I shall come back, alive or dead."

But on the morn of Saint John's Day Count Arnaud is far away.

His mother climbs to the tower window, And straight three horsemen she has seen;

On either hand a stranger knight, And good Count Arnaud rides between.

"I know by the stepping of his steed That Arnaud rides in misery;

I know by the rein in his bridle-hand My son comes sad and ill to me." 


\section{Folk-Ballads of Southern Europe}

-Ma mai, hasètz biste lou llèit, Que goaire n'i damourerèi.

Hasètz lou haut dou cabessè, Sens que ma mio ac sabe.

-O! Counte Arnaud, que bous pensatz?

Un bèt enfant que bous quitatz.

- Ni per un enfant, ni per dus, Jou que r.on resusciti plus.-

- Mèro, qu'es aço praci bas?

Semblon las oresous d'Arnaud.

-La henno que beng d'enfanta, Oresous nou diu escouta.

-Que i a? E què sounon dounc tant?

-La bèro hesto de douman.

- Se bèro hesto es douman, Quino raubo me bouteran?

- La henno que beng d'enfanta, La raubo negro diu pourta.

-Qu'es acò aqui d'escounut, Que lou counte Arnaud a escriut?

-Arré. La que beng d'enfanta, A la messeto diu ana."

Sa mio a la messo s'en ba, Bei lou counte Arnaud enterra.

- "Ma hillo, que s'en cau tourna. Belèu l'enfant que diu ploura. 


\section{Count Arnaud}

"O mother, quickly make my bed, I cannot wait," Count Arnaud said.

"Oh, make the pillows soft for me, But do not let my lady see."

"O Count Arnaud, your lady true Has borne a fair young son to you."

"Not for one child nor for twain, Shall I ever rise again."

"Mother, what sound is that below? It seems like prayers for Count Arnaud."

"A happy mother in childbed Need not listen when prayers are said."

"Why are the church-bells ringing all?" "To-morrow is high festival."

"Since to-morrow is a great feast. Tell me, mother, which robe is best?"

"A woman whose baby is newborn Should wear black robes the morrow morn."

"What is that letter? give it me! It is Count Arnaud's seal I see!"

" $\mathrm{T}$ is nothing, nothing, let it pass;

A young mother should go to mass."

Just as his wife to mass is come, They lay Count Arnaud in his tomb.

"Daughter, daughter, we must be gone, The child may wake and cry alone." 


\section{Folk-Ballads of Southern Europe}

-Aqui la clau dou men cintoun.

Tourni pas mès dens la maisoun.

Terro sacrado, et cau oubri.

Jou boi parla au men marit.

Terro sacrado, et cau barra.

Dab moun marit boi damoura.-

Bladé, J.-F.: Poésies Populaires de la Gascogne (Paris, 1882), vol. ii., pp. I34-I4I.

\section{CONTE ANZOLIN}

Co el conte Anzolin è andà a cazza

$\dot{E}$ stà morduto da un can barbin.

De sto fratempo ch'el sta a cazza

La so moglie ha avuto un fantolin.

$\mathrm{E}$ la so mare che li ha fato sapere

Che lo so moglie ha fat un fantolin:

"Se la ha avuto fè lo alevare,

Che drento il mio cuore mi sento male;

Se lo ha avuto fè lo abelire,

Che drento il mio cuore mi sento morire.

Tirè la ben ale alte ed ala lontana,

Che non la senta il suon dela campana."

"O madre più che madona!

Cossa xè che i cani così abaja?"

"O fiola più che nuoreta!

Lo sarà ala porta una povereta."

"A cao di questo poco mi cale,

Purchè il conte non avesse male.

$O$ madre più che madona!

Cossa xè ste campane che cosi suona?" 
"Keep my keys, my baby keep,

I may not come, tho' he should weep.

"Open, holy earth," she said,

"I would speak here with my dead.

"Holy earth, be closed again;

With my husband I remain."

\section{COUNT ANZOLINO}

(Venetian)

It is Count Anzolino, and he is gone a-hunting;

He is bitten by a hound, a mighty beast and wild;

And in the very hour that he has gone a-hunting His lady in her bower has borne him a man child.

It is his lady mother who comes to him, telling How the countess in her bower has borne to him a child:

"Oh, let the young mother nurse her newborn baby, But deep in my heart a deadly wound have I! Oh, let the young mother dress her newborn baby, But deep in my heart I know that I must die. Guard my love well in the highest, farthest chamber, That she may not hear the tolling of the bell."

"O my love's mother, more than my mother, Why should my lord's hounds bay so loud and late?" "O little daughter, more than my daughter, It is only a poor woman who would enter at the gate." "For all these things little am I caring, If my Lord Count is faring safe and well. O my love's mother, more than my mother, Why are they tolling, tolling the great bell?" 


\section{Folk-Ballads of Southern Europe}

"O fiola più che nuoreta!

I xè i pelegrin che vien da Roma."

"O madre più che madona!

Cossa xè sti ochi che così piangi?"

"O fiola più che nuoreta!

L'è il fumo che vien del camino."

"O madre più che madona!

Cossa xè chè i servitori così lamenta?"

"O fiola mia più che nuoreta!

L'è mort il cavalo più bel' dela stala."

"O madre più che madona!

Cossa xè chè l'Anzolin non vien trovarme?"

"O fiola più che nuoreta, El conte Anzolin è andà a cazza."

"O madre più che madona!

Che veste go i mi da meter in chiesa?"

"Metiv quela rossa o quela bianca,

O metive quela negra per usanza."

"Non voj vestir negro da vedovela, Che voj vestirmi da sposa bela.

"O madre più che madona!

Cossa xè che la gente tanto mi vardà?"

"O fiola più che nuoreta!

Xè l' usanza de vardar le done che batezza." 
"O little daughter, more than my daughter,

' $\mathrm{T}$ is only for the pilgrims who come from Rome today."

"O my love's mother, more than my mother, Why are thy dear eyes weeping tears alway?"

"O little daughter, more than my daughter, It is only the chimney that will be smoking still."

"O my love's mother, more than my mother, Why do the servants ery so loud and shrill?"

"O little daughter, more than my daughter, It is because the best of all our steeds has died." "O my love's mother, more than my mother, Why does Count Anzolin not come to my bedside?"

"O little daughter, more than my daughter, The Count Anzolin has ridden to the chase." "O my love's mother, more than my mother, To go to the church, what gown were most in place?"

"Wear the gown of rose, or wear the gown of white, dear,

Yet perhaps the gown of black is fitter than the white."

"Like a bride I will dress me in the gown that 's fairest,

Not like a little widow in weeds as black as night.

"O my love's mother, more than my mother, Why are all the people staring as I pass?"

"O my little daughter, more than my daughter, They are always staring when ladies go to mass." 


\section{Folk-Ballads of Southern Europe}

"O madre più che madona!

Cossa xè sta sepoltura così fresca?"

"O fiola più che nuoreta!

Che dele scuse io ne ho catà ben cento,

Il conte Anzolin che xè drento."

"O sepultura verde! apri le tue porte!

Che in brazzo del mio ben voglio andare.

O sepultura verde! tornati poi serare,

Che in brazzo del mio ben voglio stare."

"O fiola più che nuoreta!

Cossa farè del putel in cuneta?"

"Cola mia dote alevelo,

Cola dote del mio marì dotarè lo."

Wolf, Adolf: Volkslieder aus Venetien (May, 1864; Akademie der Wissenschaften), No. 82.

\section{L'ANELLO}

'Nucoppa la montagnella

'Ddò stanno li pastor,

Nce steano tre sorelle (bis)

$\mathrm{E}$ tutte e tre d'ammor.

Cecilia, la cchiù bella

Volette navigà';

Ppe' vede', poveriella,

Fortuna de trovà.

"Belo pescatoriello,

Vene a pescà' cchiù ccà,

$\mathrm{E}$ pescame 1'aniello

Ch'a mare mm' è cascà'." 
"O my love's mother, more than my mother, What is that grave that looks so fresh and new?" "O my little daughter, more than my daughter, I have given a hundred answers, now what shall I do? It is Count Anzolino in that new grave lies low."

"O new-made grave, let thy gates be opened, To the arms of my belovèd needs now must I go.

O new-made grave, be locked again forever, From the arms of my belovèd I will be parted never."

"O little daughter, more than my daughter, What of the child in his cradle lies asleep?"

"With my dower and my husband's care for him and keep."

\section{THE RING}

\section{(Neapolitan)}

I know a mountain valley,

I know a mountain valley,

And shepherds' huts above,

And there live three fair sisters,

And there live three fair sisters,

And all the three in love.

Cecilia will go rowing,

The fairest of them all;

Poor child, she is for knowing

What fortune may befall!

"O fisher lad, so brave and fine,

Come here and fish for me;

Come and fish out this ring of mine

That is fallen in the sea!". 


\section{Folk-Ballads of Southern Europe}

Voce de campaniello,

Respunne 'o pescator:

"Te piglierò 1 'aniello,

-Ma che mme daje allor?"

" 'Na povera zitella

Che te po' rialà?"

"D'ammore 'n' occhiatella

Basta ppe' mme pagà!"

Casetti e Imbriani: Canti Popolari delle Provincie Meridionali (Torino, I87 I-2), vol. ii., p. I I8 (Variante Napoletana).

\section{LA ERMITA DE SAN SIMON}

En Sevilla está una hermita

Cual dicen de San Simon, Adonde todas las damas ìban à hacer oracion.

Allà va la mi señora, sobre todas la mejor. Saya lleva sobre saya, mantillo de un tornasol; en la su boca muy linda lleva un poco de dulzor, en la su cara muy blanca lleva un poco de color, $y$ en los sus ojuelos garzos lleva un poco de alcohol, á la entrada de la hermita relumbrando como el sol. $\mathrm{El}$ abad que dice la misa no la puede decir, non; monacillos que le ayudan no aciertan responder, non; 


\section{The Shrine of San Simón}

With a voice like to a chiming bell,

The fisher made reply:

"Oh, I can find the ring right well, But what reward have I?"

"I am only a little maid and poor, "What should I give to thee?"

"One love-look from those eyes, be sure, Is pay enough for me."

\section{THE SHRINE OF SAN SIMÓN}

\section{(Castilian)}

In Seville there is a shrine

Called San Simón,

Where all the ladies

Go for orison.

There goes my lady,

And she's the prettiest one,

In skirt over skirt, and a mantle

That changes with the sun.

On her sweet mouth

Is a holy hush,

On her fair face

Is a little blush.

In her dancing azure eyes

Is a little alcohol;

She glistens as she enters,

Like a sunbeam on the wall.

The priest who chants the mass

Cannot chant it through;

The little acolytes

Forget what they should do; 


\author{
por decir: amen, amen, \\ decian: amor, amor.
}

Wolf y HofmanN: Primavera (Berlin, 1856), vol. ii., p. 62.

\title{
LA BELLE AU JARDIN D'AMOUR
}

La belle est au jardin d'amour,

Elle y a passé la semaine,

Son père la cherche partout

Et son amant en grande peine.

"Demande la-z-à ce berger, S'il l'a vu', qu'il nous l'enseigne."

"Berger, n'as-tu pas vu passer

Une fille la beauté même?"

"O comment est-elle vêtue?"

"Elle est vêtue en soie ou en laine,

Elle est vêtu' d'un blanc satin,

Et son mouchoir couleur de rose."

"Elle est là bas dans ces vallons, Assise au bord d'une fontaine, Entre ses mains tient un oiseau

A qui la belle conte ses peines."

"Petit oiseau, que tu es heureux

D'être dans les mains de ma belle,

Quand moi qui suis son serviteur Je n'ose pas m'approcher d'elle!

"Que sert d'être auprès du ruisseau, D'endurer la soif que j'endure?"

“ $N$ 'endure pas, mon bel ami, Buvez puisque le bon vin dure." 


\section{The Maiden in the Garden of Love 99}

Instead of singing Amen, Amen, To God above,

The boys respond Amor, Amor, Love, love.

\section{THE MAIDEN IN THE GARDEN OF LOVE (French)}

The maiden is in Love's garden,

She has lingered all the week;

Her father and her lover

Far and wide they seek.

"Ask her of yonder shepherd, Haply he may have seen." "Shepherd, have you seen passing A maiden like a queen?"

"What was the maiden's clothing, Silk, or woolen brown?" "She wore a rosy kerchief, And a white satin gown."

"She is down there in the valley, Beside the fountain's brim, She holds a bird within her hands, And tells her griefs to him."

"O birdling, thou art happy, In my love's hands so dear, While I, who am her lover, Dare not to come a-near.

"What use to bc beside the stream, And suffer thirst like mine?" "Suffer no more, my lover;

Drink, since there is good wine." 


\section{Ioo Folk-Ballads of Southern Europe}

"Que sert d'être auprès du rosier, Sans en pouvoir cueillir la rose?"

"Cueillissez, amant, cueillissez, Car c'est pour vous qu'elles sont écloses."

Smith, Victor: Vielles Chansons du Velay et du Forez, Romania (Paris, 1878), vol. vii., p. 6I.

\section{L'UCCELLO MESSAGGIERO}

S'a i sun tre sule dáime, ch'a van cojend le fiur. Tra lur a discurio:-S'a i füss sì i nostri amur!L'uzlin l'era sla rama, scutava sti discurs:

-Coza pagrie, vui bele, s'i v' fass da ambassadur? J'à dì-je la primiera:--Pagria bursëta d'or.J'à dì-je la secunda:-Pagria 'n buchet di fiur.La tersa, la pi bela:-Pagria 'n bazin d'amur.-

L'uzlin l'à sbatü j'ale, a l'è volà sla tur, Volà d'an sala an sala, n'in trova j'amatur:

-Uzlin, chi t'à mandà-te, da fè l'ambassadur?

- Mi mando tre fiete për ciamè i so amur. 


\section{The Bird Messenger}

"What use to stand beside the bush,

Nor dare the rose to take?"

"Gather the roses, dear my love;

They blossom for your sake."

\section{THE BIRD MESSENGER}

(Piedmontese)

Three ladies went a-walking Among the garden bowers;

They said: "Would we had with us

Those lovers brave of ours."

A little bird, all silent,

Listened among the flowers.

"What will you pay me, ladies, To be ambassador?"

The first said: "I will pay thee

This purse of gold, and more."

"I will pay," said the second,

"A nosegay sweet, like this."

And the third, who was the fairest:

"I will pay a true-love kiss."

The little bird went flying

Past tower and roof and tree,

From hall to hall, until he came

Where sat the lovers three.

"O little bird, who sent thee

To be ambassador?"

"Three pretty maids who sadden

To see their loves once more." 


\section{I02 Folk-Ballads of Southern Europe}

-E coza t'ành-ne dà-te, da fè l'ambassadur?

-Unha m's dáit na bursa, l'áutra ün buchet di fiur, La tersa la pi bela m'à dà 'n bazin d'amur.

-Uzlin, va dì-je ch'a speto, n'andrun seinè cun lur.-

Nigra, C.: Canti Popolari del Piemonte (Torino, I888), No. 62 A, pp. 338-340.

\section{LOU HILL DOU RÈI E SA MASTRESSO}

La bilo de Nerac

Disoun qu'es tant poulido.

Ço que n'es encoè mès,

Soun tres charmantos hillos.

La mès bèro qu'i $a$,

Dou rèi èro l'amigo.

Se lèuo de maitin,

E s'en ba a la bigno.

Lou hill dou rèi la bei:

Asta leù l'a sieguido.

A l'entrado d'un bosc,

L'a perdudo de bisto.

Rencountro un bignairoun,

Que poudauo sa bigno.

"Bignaire, bignairoun,

Que poudatz basto bigno,

Auretz pas bist passa.

Margarido, ma mio?" 


\section{The King"s Son}

"O bird, what did they pay you, These three sweethearts of ours?"

"The first paid me a purse of gold, The next a bunch of flowers;

"But the third gave me a true-love kiss, The third, who is most fair."

"Go, pray them to wait supper;

We surely will be there."

\section{THE KING'S SON}

\section{(Gascon)}

The little town of Nerac, They say it is so fair; The little town of Nerac, Three pretty girls are there.

The prettiest one of all the three

Is loved by the king's son;

She is up in the early morning, And to the vineyard gone.

The king's son he has seen her;

He follows her afar;

But he has lost her from his sight

Where the branches thickest are.

He meets with a vine-dresser,

A-pruning of his vine;

"O vine-dresser, vine-dresser!

A-pruning of your vine,

Tell me, have you seen Marguerite,

A sweetheart of mine?" 


\title{
I04 Folk-Ballads of Southern Europe
}

\author{
"Nâni, certos, moussu \\ Nou l'èi bisto, ni aujido." \\ "Cent escutz bailleri, \\ A qui me l'ensegnesso. \\ Ne bailleri plan mès: \\ Ne bailleri tres milo." \\ "Moussu, countatz l'argent. \\ Entratz deguens ma bigno. \\ Moussu, oèratz la-bas, \\ Debat aquesto aumo." \\ Que hè un ramelet, \\ De flous las mès poulidos. \\ "Hasètz-ne un per jou, \\ Margarido, ma mio." \\ "Moussu, nou podi pas: \\ Las rosos soun finidos. \\ Lou roumarin es mort: \\ E la saujo lassido."
}

BladÉ, J.-F.: Poésies Populaires de la Gascogne (Paris, 1882), vol. ii., pp. I84-189.

\section{ADIU, MARGARIDOTO}

(Cansoun d'amou)

-"Adiu, Margaridoto,

Mas prumèros amous.

Oun soun las cansounetos

Que parlauon de nous?

$-\mathrm{N}$ 'en boli entene a dise,

$\mathrm{Ni}$ n'entene a parla.

Deguens la ma floutanto,

M'en anguèrèi nega. 


\section{The King's Son}

"No, surely, monsieur, I give you my word, Not a maid this morning Have I seen or heard."

"I would give a hundred écus To one would show her me; Nay, I would give far more than that,

I would give thousands three."

"Count out your money, monsieur, Enter my vineyard here;

Look down below to yonder tree;

Is not that your dear?"

She has made a little bower,

Of the flowers that grow most sweet;

"Pray you make another

For me, Marguerite."

"No, monsieur, I cannot;

The rosemary is dead;

The roses are all fallen,

And the sage is witherèd."

ADIEU, MARGUERIDETTE

(Gascon)

"Adieu, Margueridette, My earliest love, adieu;

Where are all the little songs

That tell of me and you?"

"I will not listen to a word

That tells of you and me;

I will go and drown myself,

Floating in the sea." 


\section{I06 Folk-Ballads of Southern Europe}

- Se dens la ma floutanto,

Te bos ana nega,

Me bouterèi pescaire,

$\mathrm{E}$ t'aurèi en pescan.

-Se te boutos pescaire,

Que m'aujos en pescan,

Me bouterèi floureto,

Dens un jardin ta gran.

-Se te boutos floureto,

Dens un jardin ta gran,

Me bouterèi abeillo.

Te baiserèi souvent.

- Se te boutos abeillo,

Que me baises souvent,

Me bouterèi estelo,

Deguens lou cèu ta gran.

- Se te boutos estelo,

Deguens lou cèu ta gran,

Me bouterèi nuatge,

Te passerèi dauant.

- Se te boutos nuatge,

Que me passes dauant,

$\mathrm{Ne}$ toumberèi mourteto.

En terro m'enterreran.

- Se ne toumbos mourteto,

En terro t'enterreran,

Me bouterèi lauraire,

$\mathrm{E}$ t'aurèi en lauran. 


\section{Adieu, Margueridette}

"If you will go and drown yourself, Floating in the sea,

I will be a fisherman

And take you in my net."

"If you will be a fisherman And take me in your net,

I will make myself a little flower

In a great garden set."

"If you will be a little flower, In a great garden set,

I will turn into a bee, And kiss you every day."

"If you will turn into a bee, And kiss me every day,

I will make myself a star, In heaven so far away."

"If you will make yourself a star In heaven so far away,

I will turn into a cloud

Before your face to drift."

"If you will turn into a cloud Before my face to drift, I will quickly fall down dead And be buried without shrift."

"If you should quickly fall down dead And be buried without shrift, I will be a husbandman And find you with my spade." 


\section{I08 Folk-Ballads of Southern Europe}

-Se te boutos lauraire,

Que m'aujos en lauran-

Moun Diu, cau que te prengue,

Car es un fin galant."

Bladé, J.-F.: Poésies Populaires de la Gascogne (Paris, I882), vol. ii, pp. 360-365. 


\section{Adieu, Margueridette}

"If you will be a husbandman

And find me with your spade,

I may as well have you for my love

For a gallanter never was made." 


\section{Ballads of Murder}




\section{DONA LOMBARDA}

-Amei-me mi, dona Lombarda, amei-me mi, ameime mi.

-O cume mai volì che fassa, che j'ò 'l marì, che j'ò 1 marì?

-Vestro marì, dona Lombarda, féi-lo mürì, féi-lo mürì.

- O cume mai volì che fassa, fè-lo mürì, fè-lo mürì?

- Mi v'mustrerò d'üna manera d'fè-lo mürì, d'fè-lo mürì.

Ant êl giardin darè la caza j'è ün serpentin, j'è ün serpentin.

Piè-je la testa e pöi pistei-la, pistei-la bin, pistei-la bin; $E$ pöi bütei-la ant ël vin néiro, dè-je da bei, dè-je da bei;

Che 'l voss marì ven da la cassa cun tanta sei, cun tanta sei. 


\section{DONNA LOMBARDA}

(Piedmontese)

"Love me, oh, love me, Donna Lombarda!

Love only me, love only me!"

"I have a husband; how would'st thou have me To love only thee, to love only thee?"

- "Do him to death, Donna Lombarda, Do him to death, and love only me."

"How shall I slay him? after what fashion? To love only thee, to love only thee."

"There is a fashion, Donna Lombarda, There is a fashion easy for thee.

"In thine own garden, Donna Lombarda, Close to thy house lies a poisonous snake.

"Cut off its head, Donna Lombarda, With mortar and pestle pound it and break.

"Thou shalt poison his cup, Donna Lombarda, Even with this when he asks thee for wine;

"For thy husband will come hot from his hunting, And beg thee for wine, and beg thee for wine." 


\section{4 Folk-Ballads of Southern Europe}

-Déi-me dël vin, dona Lombarda, j'ò tanta sei, j'ò tanta sei.

Coz'j'éi-ve fáit, dona Lombarda, L'è anturbidì, l'è anturbidi.

- Ë1 véint marin de l'áutra séira l'à anturbidì, l'à anturbidì.

-Béivi-lo ti, dona Lombarda, béivi-lo ti, béivi-lo ti.

-O cume mai volì che fassa, che j'ò nin sei, che j'ò nin sei?

-L’è për la punta de la mia speja t'lo beverei, t'lo beverei.

La prima gussa ch'a n'à beivü-ne, dona Lombarda cámbia colur.

La sgunda gussa ch'a n'à beivü-ne, dona Lombarda ciama '1 consur.

La tersa gussa ch'a n'à beivü-ne, dona Lombarda ciama '1 sotrur.

Nigra, C.: Canti Popolari del Piemonte (Torino, 1888), No. I A, pp. I-3o.

\section{L'AVELLENATO}

-Dôve sî stâ jersira,

Figliuol mio caro, fiorito e gentil?

Dôve sî stâ jersira? 


\section{Donna Lombarda}

"I have so great thirst, Donna Lombarda, Give me to drink, give me to drink.

"What hast thou done, Donna Lombarda? The wine is beclouded, what dost thou think?"

r "There came in the sea-wind last night at sunset; It clouded the wine, it clouded the wine."

"Drink with me then, Donna Lombarda, Drink from the one cup, thy lips with mine!"

"Why should I drink, who come not from hunting? Why should I drink, who am not athirst?"

"Nay, thou shalt drink, Donna Lombarda; At the point of my dagger thou shalt drink first!" * $\quad * \quad * \quad * \quad * \quad * \quad * \quad * \quad * \quad *$

With the first drop Donna Lombarda Loses her color so rose-red and brave;

With the next drop Donna Lombarda Calls her confessor to shrive her and save;

With the third drop Donna Lombarda Calls for the sexton to dig her a grave.

\section{THE POISONED LOVER}

(Piedmontese)

"Where were you yesterevening, Dear son so fair and noble?

Where were you yesterevening?" 


\section{i 6 Folk-Ballads of Southern Europe}

-Sôn stâ dalla mia dama:

Signôra mama, mio core sta mal!

Sôn stâ dalla mia dama:

Ohime, ch'io moro, ohime!-

-Cossa v'hall dâ de cêna,

Figliuol mio caro, fiorito e gentil?

Cossa v'halla dâ de cêna?

-On inguilletta arrosto:

Signôra mama, mio core sta mal!

On inguilletta arrosto:

Ohimè, ch'io moro, ohimè -

-L'avì mangiada tütta,

Figliuol mio caro, fiorito e gentil?

L'avì mangiada tütta?

-Non n'hô mangiâ che mezza:

Signôra mama, mio core sta mal!

No n'hô mangiâ che mezza:

Ohimè, ch'io moro, ohime!-

-Coss'avì fâ dell'altra mezza,

Figliuol mio caro, fiorito e gentil?

Cossa avì fâ dell'altra mezza?

-L'hô dada alla cagnòla:

Signôra mama, mio core sta mal!

L'hô dada alla cagnòla:

Ohimè, ch'io moro, ohimè -

- Cossa avì fâ della cagnòla,

Figliuol mio caro, fiorito e gentil?

Cossa avì fâ della cagnòla? 


\section{The Poisoned Lover}

"I have been with my sweetheart;

O Lady Mother, sick at heart am I!

I have been with my sweetheart;

O woe is me! O woe is me! I die!"

"What supper did she give you, Dear son so fair and noble?

What supper did she give you?"

"A little eel a-roasted;

O Lady Mother, sick at heart am I!

A little eel a-roasted;

O woe is me! O woe is me! I die!"

"And did you eat the whole, then, Dear son so fair and noble?

And did you eat the whole, then?"

"Only the half I 've eaten;

O Lady Mother, sick at heart am I!

Only the half I 've eaten;

O woe is me! O woe is me! I die!"

"What did you with the leavings,

Dear son so fair and noble?

What did you with the leavings?"

"I gave them to my good hound;

O Lady Mother, sick at heart am I!

I gave them to my good hound;

O woe is me! O woe is me! I die!"

"Where have you left your good hound, Dear son so fair and noble?

Where have you left your good hound?" 


\section{8 Folk-Ballads of Southern Europe}

-L'è morta drê la strada:

Signôra mama, mio core sta mal!

L'è morta drê la strada:

Ohimè, ch'io moro, ohimè!-

-L'ha v'ha giüst dâ '1 veleno,

Figliuol mio caro, forito e gentil:

L'ha v'ha giüst dâ '1 veleno.

- Mandè a ciamà '1 dôttôre:

Signôra mama, mio core sta mal!

Mandè a ciamà 'l dôttôre:

Ohimè, ch'io moro, ohimè!-

-Perchè vorî ciamà '1 dôttôre,

Figliuol mio caro, fiorito e gentil?

Perchè vorî ciamà '1 dôttôre?

- Per farmi visitare:

Signôra mama, mio core sta mal!

Per farmi visitare:

Ohimè, ch'io moro, ohimè!-

-Mandè a ciamà '1 cürato:

Signôra mama, mio core sta mal!

Mandè a ciamà '1 cürato:

Ohimè, ch'io moro, ohimè!-

- Perchè vorî ciamà '1 cürato,

Figliuol mio caro, fiorito e gentil?

Perchè vorî ciamà ' 1 cürato?

-Per farmi confessare:

Signôra mama, mio core sta mal!

Per farmi confessare:

Ohimè, ch'io moro, ohimè! 


\section{The Poisoned Lover}

"It fell dead in the roadway;

O Lady Mother, sick at heart am I!

It fell dead in the roadway;

O woe is me! O woe is me! I die!"

"Oh, she has given you poison, Dear son so fair and noble!

$\mathrm{Oh}$, she has given you poison!"

"Now call to me the doctor;

O Lady Mother, sick at heart am I!

Now call to me the doctor;

O woe is me! O woe is me! I die!"

"Why do you want the doctor,

Dear son so fair and noble?

Why do you want the doctor?"

"That he may see what ails me;

O Lady Mother, sick at heart am I!

That he may see what ails me;

$\mathrm{O}$ woe is me! $\mathrm{O}$ woe is me! I die!

"Now call to me the curate;

O Lady Mother, sick at heart am I!

Now call to me the curate;

O woe is me! O woe is me! I die!"

"Why do you want the curate, Dear son so fair and noble?

Why do you want the curate?"

"That I may make confession;

O Lady Mother, sick at heart am I!

That I may make confession;

$\mathrm{O}$ woe is me! $\mathrm{O}$ woe is me! I die! 


\section{I20 Folk-Ballads of Southern Europe}

- Mandè a ciamà ' 1 notaro:

Signôra mama, mio core sta mal!

Mandè a ciamà '1 notaro:

Ohimè, ch'io moro, ohimè!-

- Perchè vorî ciamà ' 1 notaro,

Figliuol mio caro, fiorito e gentil?

Perchè vorî ciamà ' 1 notaro?

- Per fare testamento:

Signôra mama, mio core sta mal!

Per fare testamento:

Ohimè, ch'io moro, ohimè!-

- Cossa lassè alla vostra mama,

Figliuol mio caro, fiorito e gentil?

Cossa lassè alla vostra mama?

-Ghe lasso 'l mio palazzo:

Signôra mama, mio core sta mal!

Ghe lasso '1 mio palazzo:

Ohimè, ch'io moro, ohimè!-

-Cossa lassè alli vostri fratelli,

Figliuol mio caro, fiorito e gentil?

Cossa lassè alli vostri fratelli?

- La carrozza coi cavalli:

Signôra mama, mio core sta mal!

La carrozza coi cavalli:

Ohimè, ch'io moro, ohimè!-

-Cossa lassè alle vostre sorelle, Figliuol mio caro, fiorito e gentil?

Cossa lassè alle vostre sorelle? 
"Now call to me a lawyer;

O Lady Mother, sick at heart am I!

Now call to me a lawyer;

O woe is me! O woe is me! I die!"

"Why do you want a lawyer,

Dear son so fair and noble?

Why do you want a lawyer?"

"My will to draw and witness;

O Lady Mother, sick at heart am I!

My will to draw and witness;

O woe is me! O woe is me! I die!"

"What will you leave your mother,

Dear son so fair and noble?

What will you leave your mother?"

"I leave to her my palace;

O Lady Mother, sick at heart am I!

I leave to her my palace;

O woe is me! O woe is me! I die!"

"What will you leave your brothers,

Dear son so fair and noble?

What will you leave your brothers?"

"My carriage and my horses;

O Lady Mother, sick at heart am I!

My carriage and my horses;

O woe is me! O woe is me! I die!"

"What will you leave your sisters,

Dear son so fair and noble?

What will you leave your sisters?" 


\section{Folk-Ballads of Southern Europe}

-La dote per maritarle:

Signôra mama, mio core sta mal!

La dote per maritarle:

Ohimè, ch'io moro, ohimè!-

- Cossa lassè alli vostri servi,

Figliuol mio caro, fiorito e gentil?

Cossa lassè alli vostri servi?

- La strada d'andà a messa:

Signôra mama, mio core sta mal!

La strada d'andà a messa:

Ohimè, ch'io moro, ohimè!-

- Cossa lassè per la vostra tomba,

Figliuol mio caro, fiorito e gentil?

Cossa lassè per la vostra tomba?

-Cento cinquanta messe:

Signôra mama, mio core sta mal!

Cento cinquanta messe:

Ohimè, ch'io moro, ohimè!-

- Cossa lassè alla vostra dama,

Figliuol mio caro, fiorito e gentil?

Cossa lassè alla vostra dama?

-La fôrca da impiccarla:

Signôra mama, mio core sta mal!

La fôrca da impiccarla:

Ohimè, ch'io moro, ohimè!-

D'Ancona, Alessandro: La Poesia Popolare Italiana (Livorno, 1878), pp. I08-III. 
"A dowry for their marriage;

O Lady Mother, sick at heart am I!

A dowry for their marriage;

O woe is me! O woe is me! I die!"

"What will you leave your servants, Dear son so fair and noble? What will you leave your servants?"

"The road to go to mass on;

O Lady Mother, sick at heart am I!

The road to go to mass on;

O woe is me! O woe is me! I die!"

"What will you leave for your funeral, Dear son so fair and noble? What will you leave for your funeral?"

"A hundred and fifty masses;

O Lady Mother, sick at heart am I!

A hundred and fifty masses;

O woe is me! O woe is me! I die!"

"What will you leave your sweetheart, Dear son so fair and noble?

What will you leave your sweetheart?"

"The gallows-tree to hang her;

O Lady Mother, sick at heart am I!

The gallows-tree to hang her;

$\mathrm{O}$ woe is me! O woe is me! I die!" 


\section{I24 Folk-Ballads of Southern Europe}

\section{LA FILLE DE SAINT-MARTIN DE L' ILE}

C'-était un' jeune fille

De Saint-Martin de 1' Ile,

$\left.\begin{array}{l}\text { Son pèr'l'a marié' richement, } \\ \text { Mais point à son contentement. }\end{array}\right\}$ (bis)

Elle avait un' bell'-mère,

Un' méchante bell'-mère,

Qui toujours disait à son fi':
"Mon fi', quand la f' ras-tu mouri'?" $\}$

"Patientez, ô ma mère,

$\mathrm{O}$ ma très chère mère;

Patientez à dimanch' matin, $\left.{ }^{\text {J' accomplirai tous vos desseins." }}\right\}$ (bis)

La belle tout en larmes

Alla trouver son père,

Lui dir' ses craint' et ses peri's

Et qu' on voulait la fair' mouri'.

"Ah! mon père, ah! mon père,

$\mathrm{Ah}$ ! mon très chèr père,

Vous $m$ ' avez donné un mari,

Je crois qu' il me fera mouri',",

"Retourne-t-en, ma fille, Chez toi, ma bonne fille, Avant dimanche, avant lundi, J' irai parler à ton mari."

La belle s' en retourne, S' en retourne chez elle; Elle se couch' dessus son lit, ? Ne tarde pas à s' endormi'. 


\section{THE MAIDEN OF SAINT-MARTIN-DE-L'ILE (French)}

Of a maiden they are telling, At Saint-Martin she was dwelling;

To a rich-man she was wed, And the young bride lived in dread.

Her mother-in-law was wicked, Oh, she was very wicked! She said every day of her wicked life: "My son, when will you kill your wife?"

"Be patient, O my mother! Be patient, my dear mother! Till Sunday come again, be still, And Sunday you shall have your will."

The fair bride goes a-weeping To her father for safe-keeping;

She tells him how in dread and fright She lives in peril day and night.

"O father! O my father! My dearest, dearest father, You have made me a cruel rich-man's wife, And I know that he will take my life."

"Go back now, my good daughter, Go home, my little daughter; On Sunday or Monday of the week, To your husband I will surely speak."

And so the sorrowful little bride Goes home to her own fireside; On her bed, too tired to weep, She lies, and quickly falls asleep. 


\section{I26 Folk-Ballads of Southern Europe}

A l' instant dans la chambre

C' est son mari qui entre:

"Belle, prenez vos jupons blancs,

Nous allons faire un tour aux champs."

Sans attend' la réponse

Sur son ch'val il la monte;

"Holà! ma bell", tenez-vous bon, ?

Nous allons jouer de l' éperon."

Tout aussitôt galope,

Sans débrider l'emporte,

Jusqu' à la pièce de froment

Où son épée était dedans.

"Mari, si tu m' y frappes,

Va-t-en chercher un prêt'e,

Que je lui fass' confession,
Pour en avoir absolution." (bis)

“'Tu n' auras d' autre prêt'e

Que l' bout de mon épée.

$\left.\begin{array}{l}\text { Il te donn'ra ta confession } \\ \text { Et mon poignard 1' absolution." }\end{array}\right\}$ (bis) .

Revenant par derrière,

Rencontre son beau-frère:

" $A h$ ! d' où viens-tu, frère, maintenant?

Tes souliers sont couverts de sang."

"Je reviens de la chasse

Des lapins, des bécasses;

$\left.\begin{array}{l}\text { J' tant tué de lapins blancs } \\ \text { Qu' mes souliers sont couverts de sang." }\end{array}\right\}$ (bis) 
Suddenly her husband stands

At her bedside and commands:

"Fair bride, put on your skirts of white;

We two ride through the fields to-night."

He does not wait for a reply,

To mount her on his saddle high:

"Fair bride, hold fast," he cries to her:

"Hold hard, for I shall use the spur."

Thus he gallops at full speed,

Nor draws the rein upon his steed

Till they have come to a wheat field

Where his bright sword lies concealed.

"If you will murder me, at least

Go and find for me a priest;

That I may confess, and he

May absolve and pardon me."

"Not a priest can I afford,

But the bright point of my sword;

Your confession it will take,

And my dagger short shrift make."

Home again as he will ride,

He meets the brother of his bride:

"Where have you been?" her brother said;

"Your shoes are covered all with red."

"I am riding from the chase, Wherc I killed woodcock, many a brace;

So many white hares I left dead, My shoes with blood are covered red." 


\section{Folk-Ballads of Southern Europe}

"Tu as menti, beau-frère,

Ah! tu n'es qu'un faux traitre,

Je vois à tes pales couleurs

Que tu viens de tuer ma soeur."' $\}$ (bis)

Va prév'nir la justice,

La prév'nire du crime:

"Justice, faites-le mouri', , $\}$ (bis)

Bujeaud, J.: Chants et Chansons des Provinces de l'Ouest (Niort, 1866), vol. ii., pp. 226-229.

\section{LE MEURTRE DE LA MIE}

"Donnez-moi ma chemise blanche,

A la messe je veux aller."

"Tu veux pas aller à la messe,

Tu veux aller voir ta maîtresse."

"Qu' avez-vous donc, cruelle mère?

Car toujours vous m' en parlez."

"Je voudrais que le coeur de ta mie, Je voudrais qu' il soit crucifié."

"Que me donnerez-vous, mère, Pour aller vous le chercher?"

"Cent écus dans ma boursette, Cent écus je te donnerai."

"Cent écus n' est pas grand chose

Pour tuer ce que l' on aimait." 


\section{The Murder of the Sweetheart}

"Brother-in-law, you lie," he cried;

"It is not white hares that have died;

By your pale cheeks, I see too plain

It is my sister you have slain."

He has gone to tell the court:

"Justice, let his days be short;

Hang him on the gallows grim,

Hang his mother after him."

\section{THE MURDER OF THE SWEETHEART}

\section{(French)}

"Give me my white shirt, Mother, pray,

I will go to mass to-day."

"You are not going to mass, I trow, To visit your sweetheart, son, you go."

"Mother, you speak so cruelly!

What is it that you want with me?"

"I want the heart of your promised bride, And I wish that it were crucified."

"Mother, how much money will you pay

To me, if I bring it to you, say?"

"A hundred écus I will give;

They are in my purse there, as I live."

"A hundred écus is pay but small

For killing what one loves best of all." 


\section{I30 Folk-Ballads of Southern Europe}

"Tiens, va-t-en donc vers ta mie, Pour son coeur me l' amener."

Mais le galant n' a pris son épee, Chez sa mie s' en est allé.

S' en va frapper à la porte, A la porte de sa mi':

"Qui est-ce qui frappe à ma porte, Qui m' empêche de dormi?"

" $C$ ' est mon tendre coeur, la belle, Qui désire de te voir."

Il l' a prise par sa main blanche:

"Allons, mie, nous promener."

Mais quand ils furent dessous une ombre: "Allons, mie, il faut mourir!"

" $N$ ' aurais-tu donc le courage De me faire mourir ici?"

"O courage que courage!

Allons, mie, te faut mourir!"

Mais le galant n' en tire son épée, Dans son coeur il l' a plongé.

"O tenez, ma cruelle mère, Ce que tant vous désirez!" 


\section{The Murder of the Sweetheart I3I}

"Enough, now go and see your dear, And bring me her heart when you come back here."

He has slung his sharp sword at his side, And gone to visit his promised bride.

He knocks at the door with a noisy din, That his sweetheart may let him in.

"Who is it knocking at my door, So loud that I can sleep no more?"

"Your tender-hearted love is here To visit you, my pretty dear."

He takes her hand so white and slim, And leads her out to walk with him.

When they 're under the trees so thick and high:

"Come now, my dear, for you must die!"

"O my lover, have you no fear?

Have you the heart to kill me here?"

"Afraid? Now who 's afraid? Not I!

Come, my dear, for you must die!"

The youth has drawn the sword at his side, And stabbed the heart of his promised bride.

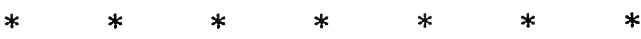

"Here, take it! O my crucl mother!

' $\mathrm{T}$ is the thing you wanted, and no other." 


\section{$\$ 32$ Folk-Ballads of Southern Europe}

" $\mathrm{C}$ ' est pas le coeur de ta mie,

Non, c' est le coeur d' un animau."

" $C$ ' est bien le coeur de ma mie,

C' est pas le coeur d' un animau.

"Tout garcon qui tue sa mie

Ne doit pas rester au pays.

"Donnez-moi ma chemise blanche

Et aussi mon manteau gris.

"Je m' en vais à la guerre,

Ou dans l' étrange pays."

$N^{\prime}$ en fut pas rentré-z-à la porte,

Les gens d' armes n' ont entré.

Si l' ont pris, ils l' ont mené,

A la potence ils l' ont monté.

SMITH,VICTOR: Chants Populaires $d u$ Velay el du Forez, Romania

(Paris, 1881), vol. x., pp. 196-197.

\section{BELL' JEANNETON.}

"Veux-tu venir, bell' Jeanneton,

Le long de la mer coulante,

Nous promener tout au long?

Y a du plaisir. Nous en prendrons."

Quand ils fur' sur le bord de l' eau,

La belle lui demande à boire;

"Avant de boir' de ce vin blanc,

Bell', je veux boire de ton sang."

"Mon cher amant, mon bien-aimé,

En aurais-tu bien le courage?"

"Allons ho! belle Jeanneton, Quitte vîte tes blanc jupons." 


\section{Fair Jeanneton}

"' $\mathrm{T}$ is not the heart of your love at all, No, it 's the heart of some animal."

"It is surely her heart and no other, ' $T$ is not the heart of a beast, my mother.

"A youth who has murdered his sweetheart, From his own country must depart.

"Give me my white shirt, Mother, pray, And give me also my mantle gray,

"For to the war, now, I will go;

Or to some country I do not know."

He has not walked across the floor, When the soldiers enter at the door.

They take him and lead him out to die; Upon the scaffold they lift him high.

\section{FAIR JEANNETON (French)}

"Will you come with me, fair Jeanneton, To walk in the pleasant weather? We will go along the water's edge, And sport and play together."

When they came to the water's edge,

She was athirst, she said:

"Rather than drink of this white wine,

I will drink your blood so red."

"O my dear love, my own true love!

How dare you treat me so?"

"Oh, come, fair Jeanneton, lay off

Your skirts as white as snow." 


\section{I34 Folk-Ballads of Southern Europe}

"Mon cher amant, mon bien-aimé, Tire mes bas, dis, je t' en prie?" Tant qu' il tirait les bas du pied, Dedans la mer l' a fait plonger.

Le beau galant subtilement S' est attrapé à-z-une branche; La Jeanneton prend son couteau, Coupe la branch', l' envoie-t-à l' eau.

"Oh! tire-moi, ma chère belle, Que je retourne chez mon p re." "Ah! non! oh! non! maudit galant, Puisque tu z-y es, reste-z-y donc."

"Ma chère ami', ma bien-aimée, Donne-moi la main, je t' en prie." "Oh! non! oh! non! maudit galant, Faut aller voir la mer au fond."

"Rossignolet du bois joli, Va-t-en dire à ma chère mère, Va-t-en lui dir' que je suis mort, Et qu' Jeanneton n' a pas tout l' tort."

Bujeaud, J.: Chants et Chansons des Provinces de l' Ouest (Niort, 1866), vol. ii., pp. 232-233.

\section{UN' EROINA}

El fiöl dij signuri cunti s'a l'è chiel n'in va ciamè, Va ciamè d'üna Munfréina, la fia d'ün cavajè. 
"O my dear love, my own true love! Pull off my shoe for me."

But while he pulled it from her foot, She threw him in the sea.

The youth has caught a branch of tree, He holds with might and main;

But Jeanneton with her penknife Has cut the branch in twain.

"Oh, save me! save me! my true love! I drift away so far!"

"Oh, no; oh, no, you cruel youth! You may stay where you are."

"O my dear love, my own true love, Reach out your hand to me!" "Oh, no; oh, no, you cruel youth!

You must sink to the depths of the sea!"

"O nightingale in the greenwood, Fly to my mother's door; Tell her my love is not to blame That I come home no more."

\section{A HEROINE}

\section{(Piedmontese)}

It is the son of my Lord Count, $\mathrm{He}$ goes a-wooing far from here; He goes to woo a Monferrine, The daughter of a cavalier. 


\section{I36 Folk-Ballads of Southern Europe}

S'a l'e 'l saba la va 'mpromēt-la,

dì dumëgna la va spuzè.

L'à meinà sinquanta mia sensa mai parlè-je ansem.

Prima vota ch'a j'à parlà-je, s'a j’à ben cozì parlà:

"Guardè là, bela Munfréina, cul castel tan ben mürà.

Mi sinquanta e due Munfréine mi là drin j'ò già meinà; Le sinquanta e due Munfréine mi la testa e j'ò cupà.

N'autertant farai, Munfréina, quand che vui n'a sarì là."

"O scutè, lo signur cunte, prëstè-me la vostra spà."

"O dizì, bela Munfréina, coza mai na völi fà?"

"Vöi tajè na frascolina për fè umbra al me caval."

Quand la bela l'à 'biü la speja, ant ël cör a i l'à piantà.

"O va là, lo signur cunte, o va là 'nt i cui fossà!"

L'à virà al caval la brila, andarè 1'è riturnà.

Ël primier ch'a na riscuntra, so fradel n'à riscuntrà. 


\section{A Heroine}

On Saturday they are betrothed,

On Sunday morn he goes to wed;

$\mathrm{He}$ has carried her for fifty miles,

And not a word between them said.

But he speaks to her at the last,

After she has waited long:

"Yonder look, fair Monferrine,

To that castle walled so strong.

"Two-and-fifty Monferrines

There already I have led;

Two-and-fifty Monferrines,

And I struck off every head.

"I will do the like to yours

When we 're there, I give my word."

"Listen, listen, Signor Count,

Will you lend to me your sword?"

"What will you do with my sword,

When you have it, Monferrine?"

"To shade my horse from the hot sun,

I will cut a branch of green."

When she has the sword in hand,

In his heart she plants it deep;

"Oh, lie there, my Signor Count;

In that low ditch you shall sleep!"

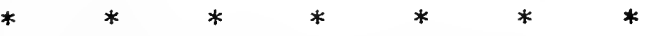

She has turned her bridle-rein;

She rides swiftly from the place, Meets with no one till she meets

Her own brother, face to face. 


\section{I38 Folk-Ballads of Southern Europe}

"O dì 'n po', bela Munfréina, l'è d'assè che 't trove sì!"

"J'ò trovà i sassin di strada, l'àn massà-me '1 me marì."

"O dì 'n po', bela Munfréina, t' l'avrei nen massà-lo ti?"

"O sì, sì, me fradelino, la vrità ch'a fa bel dì;

A sun pa i sassin di strada l'àn massà-me me marì."

"O dì 'n po', bela Munfréina, a cà tua venta turnè."

"O no, no, me fradelino, a cà mia vöi pa pi andè. Mi na vöi andè a Ruma, 'nđè dal papa a cunfessè."

Nigra, C: Canti Popolari del Piemonte (Torino, 1888), No. I3 A, p. 90 .

\section{ROMANCE DE RICO FRANCO}

A caza iban, á caza

Los cazadores del rey,

$\mathrm{Ni}$ fallaban ellos caza,

$\mathrm{Ni}$ fallaban que traer.

Perdido habian los halcones,

Mal los amenaza el rey!

Arrimáranse á un castillo

Que se llamaba Maynes.

Dentro estaba una doncella

Muy fermosa y muy cortes;

Siete condes la demandan,

$\mathrm{Y}$ asi facian tres reyes. 


\section{The Ballad of Rico Franco}

"Tell me now, fair Monferrine, Why you ride alone?" he said;

"Oh, I met with highwaymen, My bridegroom they murderèd."

"Tell me now, fair Monferrine, Was it you who slew your lord?' "Yes, my brother, truth is best, I have slain him with his sword.

"I have slain him with his sword; No highwaymen have I seen." "You must go home to your house; Come with me, fair Monferrine."

"Oh, no, no! my brother dear, I can never more go home;

I go to confess myself To the Holy Pope at Rome."

\section{THE BALLAD OF RICO FRANCO}

\section{(Castilian)}

They have ridden out a-hunting,

The huntsmen of the king;

They have sought for game the whole day long,

Nor taken anything;

They have lost the royal falcons

And fear to face the king.

They ride along the highroad

Till a castle comes in sight

Where lives a noble maiden,

So beautiful and bright,

That three kings are her wooers,

Three kings, and many a knight. 


\section{I40 Folk-Ballads of Southern Europe}

Robárala Rico Franco,

Rico Franco aragones:

Llorando iba la doncella

De sus ojos tan cortes.

Falágala Rico Franco,

Rico Franco aragones:

"Si lloras tú padre ó madre,

Nunca mas vos los vereis,

Si lloras los tus hermanos,

Yo los maté todos tres."

"Ni lloro padre ni madre,

$\mathrm{Ni}$ hermanos todos tres;

Mas lloro la mi ventura

Que no sé cuál ha de ser.

Prestédesme, Rico Franco,

Vuestro cuchillo lugues,

Cortaré fitas al manto,

Que no son para traer."

Rico Franco de cortese

Por la cachas lo fué tender;

La doncella que era artera

Por los pechos se lo fué á meter:

Asi vengó padre y madre,

$\mathrm{Y}$ aun hermanos todos tres.

Wolf y Hofmann: Primavera (Berlin, I856), vol. ii., pp. 22-23. 
Now Rico Franco steals her,

Rico Franco of Aragon;

Though the tears of the sweet maiden

From her pretty lashes run;

He taunts her, Rico Franco,

Rico Franco of Aragon.

"What use to mourn thy parents,

Whom thou shalt never see?

What use to mourn thy brothers?

I have slain them, all the three!"

"I weep not for my parents,

Nor for my brothers three;

I weep for mine own fortune.

Who knows what it will be?

"Now lend me, Rico Franco,

Your knife so bright and bare,

For the fringes of my mantle

They are not fit to wear."

The courtly Rico Franco

Held out to her the hilt;

But the maiden she was crafty

And swift his blood was spilt.

In his breast the knife she buried

That she revenged might be

For her father and her mother,

And her brothers, all the three. 


\section{42 Folk-Ballads of Southern Europe}

\section{LO COMPTE GARÍ}

Estava agenollada-donzella Beatris, mentres oraciò feya-ne vè un jove gentil.

Cull un pom de violas-pera ferla dormir, quan la tè adormideta-en gropa la puji.

Caminaren set lleguas-que may se desperti, al cap de las set 1leguas-la dama 's deixondi.

- Prenéumen per esposa-lo bon compte Garí. -No 'us vull pas per esposa-d'esposa ja me'n tinch mes blanca, mes hermosa,- mes bella, mes gentil. Vos filaréu 1 estopa,-ella filará '1 11í-

Treu lo cap en finestra-la dama y fa un sonris. -De que riéu la dama,-donzella Beatris?

-De que veig veni' '1 pare,--cavallers mes de mil, portan una bandera-que hi canta un estorlich 


\section{Count Gari}

\section{COUNT GARÍ}

(Catalan)

Lady Beatris is kneeling, Kneeling to pray;

And while the lady 's praying,

A fine youth comes that way.

With the violets he 's holding,

In sleep he makes her droop;

And when she 's sleeping soundly

He lifts her to his croup.

Seven leagues they ride together,

Still she 's sleeping sound;

When for seven leagues they 've travelled,

She wakes and looks around.

"For your wedded wife now take me,

My good Count Garí."

"For my wife I will not have you;

I have a wife," said he,

"More beautiful, more charming,

More white, more nobly bred;

The tow you will be weaving,

And she the linen thread."

* $* * \quad * \quad * \quad * \quad * \quad * \quad * \quad *$

With her head at the window,

She looks with a smile:

What is the lady seeing,

That she laughs the while?

"I see my father coming

With knights a thousand strong.

They bear a blazoned banner;

And I hear its starling's song, 


\section{I44 Folk-Ballads of Southern Europe}

que diu ab son llenguatge: "Garí n' has de morir."

- Cobreixme ab las cortinas-dirás que no $\mathrm{m}^{\prime}$ has vist.

Ja trucan á la porta-responen: "Qui hi ha assí?" - Hauriau vist al compte-al compte Don Garí?

Los diu que no ab la llenga,--sos ulls diuhen que sí.

Aixecan las cortinas-y matan Don Garí. Quan fou lo cap á terra-aquestos mots va dir: -Be n' estarás contenta-donzella Beatris, que ne tindrás la testa-del compte Don Garí. -Jo no la vull la testa,- de testa ja me 'n tinch mes blanca, mes hermosa,-mes bella, mes gentil.

Briz y SaLtó: Cansons de la Terra (Barcelona, I867), vol. ii., pp. $47-52$.

VOCERO DI MARIA FELICE DI CALACUCCIA IN MORTE DEL FRATELLO

Eju filava la miò rocca,

Quandu intesu un gran rumore:

Era un colpu di fucile

Chè m'intrunò nu lu core, 


\section{Lament of Maria Felice Di Calacuccia 145}

"That says in his bird language:

"The Count Garí must die.",

"Cover me with the curtains;

Don't say that it is I!"

At the door they are a-knocking;

She says: "Who may you be?"

"Now tell us have you seen the count,

The count Don Garí?"

It 's "no" her tongue is saying;

It 's "yes" that her eyes say.

They draw aside the curtains,

And Count Gari they slay.

When his head was on the pavement,

It spoke and said this:

"Oh, now you will be happy,

Donzella Beatris,

"For you can have the head now

Of the count Don Garí."

"His head I am not wanting,

I have a head," said she;

"His head I am not wanting,

I have a better head;

More beautiful, more charming,

More white, more nobly bred."

\section{LAMENT OF MARIA FELICE DI CALACUCCIA} FOR THE DEATH OF HER BROTHER

\section{(Corsican)}

I was spinning with my spindle

When a loud noise made me start;

' $T$ was the firing of a musket,

In my breast I felt the smart; 


\section{46 Folk-Ballads of Southern Europe}

Parse ch' unu mi dicissi

Corri, $u$ to fratellu more.

Corsi in camera suprana, E spalancaju la porta. Ho livatu indu lu core, Disse, e eju cascaju morta. S'allora nun morsu anch' eju Una cosa mi cunforta.

Bogliu veste li calzoni, Bogliu cumprà la terzetta, Per mustrà la to camiscia Tantu nimmu nun aspetta A tagliassi la sò varba Dopu fatta la bindetta.

A fane la to bindetta Quale voli che ci sia? Màmmata vicinu a more?

$\mathrm{O}$ a to surella Maria?

Oh! si Lariu unn 'era mortu, Senza strage nun finia.

D'una razza così grande

Lasci solu una surella, Senza cugini carnali

Povera, ofana e zitella. Ma per fà la to bindetta, Sta siguru, basta anch'ella.

Marcagi, J. B.: Les Chants de la Mort et de la Vendelta (Paris, 1898), pp. 176-179. 


\section{Lament of Maria Felice Di Calacuccia 147}

And it seemed a voice said: "Hurry!

They have struck your brother's heart."

I ran to the upper chamber,

Very wide I threw the door;

He said: "They have killed me, sister!"

I fell senseless on the floor.

If one thought did not sustain me,

I'd not live an hour more.

I will dress in coat and trousers;

I will buy myself a gun;

I will show thy shirt all bloody,

For no man remains, not one,

Who will leave his beard unshaven

Until he sees vengeance done.

Who is there to make vendetta?

Mother, dying on her bed?

Sister Maria? Brother Lario?

$\mathrm{Oh}$, that Lario were not dead!

For if Lario were living,

Blood enough would soon be shed!

Now of all our many kindred,

None is left to fight for me;

Thy poor sister, maiden, orphaned,

Swears her lonely vow to thee:

Be thou sure, for thy vendetta

She is ready, even she! 


\section{I48 Folk-Ballads of Southern Europe}

\section{LA MARQUISE}

Quand le roi entra dans la cour,

Pour saluer les dames,

La plus belle, par son amour,

Elle a ravi son âme.

Le roi demande à ces messieurs:

"A qui est cette dame?"

Le beau marquis a répondu:

"Cette-là, c'est ma femme."

"Marquis est plus heureux qu'un roi,

D'avoir si belle dame,

Car, je le jure sur ma foi,

Je la prends pour ma femme."

Le beau marquis a dit au roi:

"Vous faites injustice.

Ma femme m'a promis sa foi;

Je quitte le service."

Le roi l'a prise par la main,

L'a menée en sa chambre;

La belle, en montant les degrés,

Pleurait toutes ses larmes.

"Marquise, ne pleurez pas tant;

Quand vous serez princesse,

De mon or et de mon argent

Vous serez la maitresse." 


\section{The Marquise}

\section{THE MARQUISE}

(French)

When the king comes into the court

To greet the ladies there,

One has stolen away his heart,

The one who is most fair.

"Whose wife is she, my gentlemen?"

A marquis proud replied:

"That fairest lady of them all

Is my wedded bride."

"Marquis is happier than king With a lady so divine;

But I swear to you upon my faith

I must have your wife for mine."

The good marquis has answer made:

"King's justice is but short;

My wife has promised faith to me.

Sire, I leave the court."

The king has taken her by the hand

In court before them all;

But as he leads her up the stair,

Her tears like thick rain fall.

"Weep not so bitterly," he said;

"My noble Marchioness;

Of all my silver and my gold

You shall be mistress." 


\section{I5 5 Folk-Ballads of Southern Europe}

L'a reine lui donne un bouquet

Fait de fleurs tant jolies;

Mais en flairant ce beau bouquet,

Elle a perdu la vie.

Le roi lui fit faire un tombeau

En terre de Baise,

Et il a fait tracer en haut

Le nom de la marquise.

Les gens ont dit au beau marquis:

"Priez pour votre dame."

"Dieu lui ferme son paradis;

Je n'ai ni roi ni femme."

BladÉ, J.-F.: Poésies Populaires en Langue Française (Paris, I879), pp. 25-26. 
The queen gives her a fair nosegay

Sweet with the rose's breath;

The odor of that fair nosegay

Brings her to her death.

The king has built for her a tomb

In the province of Baise;

Above is cut into the stone

The name of the marquise.

The folk have bid the good marquis:

"Now pray for your dead bride."

"God shuts her out of Paradise;

I 've nor king nor wife," he cried. 
Ballads of Prisoners 


\section{BUJOR}

Frunḑă verde de negară;

A eșit Bujor în ţéră!

Bate, pradă, nu omóră

Pe cĭocoĭ î̉ bagă 'n fíare,

Se-ı̆ dea banĭ de cheltuială

Şi haine de priminélă.

Bujor ese, Bujor dice:

"Halal de tine, voĭnice!

Haĭdeţŭ copiŭ după mine

Că stiŭ calea 'n codru bine,

Şi stiŭ turme de berbeč̆,

Isvóre cu ape recr̆,

Şi neveste frumuşele

Şi desagì cu rubiele!"

Icĭ în vale, colé 'n vale

Sună-un glas duios cu jale,

Glas frumos de fată mare,

Bujor prinde-o sărutare!

Icĭ în vale, pîrîŭ

Doă fete spală grîŭ, Bujor le tine de brîŭ! 


\section{BUJOR}

(Roumanian)

Green leaf of the meadow-grass!

Bujor throughout the land doth pass!

He beats, he robs, he does not kill.

The tyrant nobles at his will

With their gold must pay his way,

And give him clothes for every day.

Bujor comes and cries aloud:

"Good luck to thee, my soldier proud!

Follow, children, after me;

I know where the wood-paths be;

I know where are flocks of sheep,

Springs of water, clear and deep,

Where fair women may be found,

And sacks of gold upon the ground."

In the valley, here and there,

A maiden's sad voice fills the air;

Like a mermaid singeth she,

Bujor robs her of kisses three.

By the stream down in the plain,

Maidens two are washing grain;

' $T$ is Bujor halts in the place,

And gives to each girl an embrace. 


\section{I56 Folk-Ballads of Southern Europe}

Icč în vale, la fontână,

Doă fete spală lână,

Bujor le strînge de mână!

Icĭ în valea luĭ Terinte,

Doă fete culeg linte,

Bujor le scóte din minte!

Frunḑă verde de negară;

La Focşanĭ între hotară,

Este-un bordeŭu cam plecat

De copacĭ încungŭurat.

Acolo-ǐ Bujor culcat,

La Aniţa veduviţa,

Ce'u dă vin tot cu vădriţa

Si'l îmbată cu guriţa:

"Aniţico, draga mea!

Mult mĭ-e dor de-o floricea,

Floricică rumeóră

Care-o porţư în buzișóră.

-Stefănică Bujoraș!

Floricica daţu-o-aş.

$\mathrm{Na}$ şi na guriţa mea

De-o sărută cât î̀ vrea.

Ear de beut, nu mal̆ bea

Că potira-ĭ cât colea.

-Las' se vie că nu'mĭ pasă

Când mü-e paloșul pe masă

Şi mîndruţa drăgăstósă."

Sărutatul n'aŭ sfîrșit,

Potira c'aŭ şi sosit.

Luptat-aŭ Bujor, luptat,

De potiră n'a scăpat! 


\section{Bujor}

In the valley by the pool,

Two fair maids are washing wool;

While each maiden washing stands,

Bujor presses her white hands.

Down the stream two girls have strayed,

Gathering lentils in the shade;

Both girls Bujor has betrayed.

Green leaf of the meadow-grass!

On the frontier lives a lass,

In a tavern scarcely found

For the forest all around;

It is here Bujor is hidden

With Anita the inn-maiden.

Before him a great flask she places,

She makes him drunk with her embraces.

"O Anita, sweetheart mine,

For a small red flower I pine,

Blossomed on that mouth of thine!"

"Stefanica, Bujor dear,

Have thy little flower here;

All my kisses, they are thine,

Take them, but take no more wine,

Not a drop more, for I fear

That the guards are hidden near."

"Let them come, I'm not afraid,

On the table lies my blade,

And my love 's the fairest maid!"

He takes one kiss and no more, For the guards are at the door!

Fierce he fought as a man may,

Bujor could not escape that day. 


\section{Folk-Ballads of Southern Europe}

Frunḑă verde de negară,

Pe Bujor mi'l duc pin țéră

De'l arată ca pe-o féră!

Şi mi'l pun la închisóre,

Fără arme, fără sóre!

Olǐolio! codru frunḑos

Cât esti vara de frumos

Earna putred̦escĭ tu gios!

$\mathrm{Ca}$ tine Bujor în gros

Sta culcat cu facĭa 'n gros.

Frunḑă verde de negară,

Pe Bujor mi'l gŭudecară,

La Divan îl întrebară,

Mulţu crestinŭ de-a omorît

Cât pin ţéră a hoţit?

Ear Bujor cruce 'şi făcea

Si cu dreptul respundea:

“Mort de om eŭ n'am făcut,

Dar cĭocoĭ mulţ̆ am bătut!

- Stefane Bujorule

Unde-ţ̌ sunt averile

Ca se-ţ̌ scapŭ tu ḑilele?

-Le-am ascuns pe la copacr,

De-agŭutor la ceĭ săracĭ

Se-şi cumpere boĭ şi vacǐ!"

Frunđ̧ă verde de negară,

Bujor se sue pe-o scară .

Plâng săracĭ cu jale-amară,

Că nu-ĭ scara Domnilor

Şi e scara hoţilor,

Calea négră-a morţilor!

AlecsandRi, VAsile: Poesǐ̌ Populare ale Românilor (Bucuresci, 1866), pp. 156-158 
Green leaf of the meadow-grass!

Bujor throughout the land must pass

Like a wild beast to be shown!

Till within a cell he 's thrown,

Without arms or light, alone!

Forest thick, with branching shade,

Thy fair leaves shall low be laid,

Round about thy feet to fade!

Even so Bujor is found,

With his face upon the ground!

Green leaf of the meadow-grass!

For his trial now, alas!

Bujor to the court must pass.

"Famous bandit, speak and say,

Many Christians dost thou slay?"

"Not a man to death I 've done;

But I 've thrashed tyrants many a one!"

"Stefanica, Bujor bold,

Where dost thou conceal thy gold?

If thou would'st escape now, tell!"

"Under trees 't is hidden well;

Poor men shall find that gold of mine,

And with it buy oxen and kine."

Green leaf of the meadow-grass!

Up the stair Bujor must pass.

Poor men for him wail and cry:

' $T$ is not the stairway of the high,

Not the stairway to great place,

But the ladder of disgrace,

Where bandits and where thieves are led,-

The black footpath of the dead! 


\section{I60 Folk-Ballads of Southern Europe}

\section{FRA DIAVOLI}

Amici, rimittémunni,

Pensa ch' è mala vita,

Di sti valenti omini

La libertà è finita.

Pigghiámunni l'esempiu

Di sti gran curaggiusi,

Chiamati Fra Diauli,

Picciotti spiritusi.

Chist'omini di spiritu

Lu só curaggiu 'un vali;

Cà di stu tempu válinu

$\mathrm{Li}$ babbi e li minnali.

Dintra 'na scura cammara

Su' misi a la catina

'Nt' ô casteddu tirribuli

Di Santa Catarina.

A li trenta d'austu

Ddà tinniru un complottu

Si misinu d'accordiu,

$E$ oniti foru ottu.

E tutti ottu pensinu

Lu modu di scappari,

E una corda ficinu

Putírisi jttari.

$\mathrm{Cu}$ ferramenti levanu

Li grati cchiù maggiuri,

Lu Ninu Fra Diáulu

Si jttau cu fururi. 


\section{The Brothers Fra Diavoli}

\section{THE BROTHERS FRA DIAVOLI}

\section{(Sicilian)}

Listen to this evil tale!

Friends, let us awaken!

Hear how from these valiant men

Their liberty is taken.

Let us our example find

When our courage 's wanted,

In the Fra Diavoli,

Brothers three, undaunted.

In these times were all for naught

Their bravery of spirit,

Now, when scamps and little rogues

Count more than men of merit.

In a dark and horrid cell, Its window iron-grated,

In the castle of Saint Catherine, They lie, with great chains weighted.

It was August thirtieth

The brothers their word plighted

With five other prisoners,

And all the eight united;

All the eight with all their wits

Plotted and planned together, Till, at last, a little rope

To the window-bar they tether.

Then with irons they pried up

The big grate from its socket, And Ninu Fra Diavolo

Went out like a rocket. 


\section{I62 Folk-Ballads of Southern Europe}

L'autri setti scinninu

Scausi senza scarpi,

A praja 'i mari arrivanu

Facennu longhi tappi.

Una barcuzza scoprinu

A tiru di scupetta;

'Nnatuni si jttau

Lu gran Ninu Buzzetta.

' $N$ terra la barca porta

Ddà intra cc'era tri omini,

Una scupetta avianu

Spinsirati durmianu.

Tutti ottu si 'mbarcanu

Vucannu cu riguri

Pizzu 'i Gallina arrivanu

'Ntra termini ddu' uri;

Tutti ottu sbarcaru.

E chiddi li ssrugghieru;

Scarpi e cosetti cercanu,

E ddoppu si jarmaru.

Mentri chi caminávanu

Ma iddi pi ddi strati

'N attirruri facíanu

Pi tutti ddi cuntrati.

Di Palermu si parti

'N gran populu d'aggenti,

Surdati 'n quantitati

Cavallaria e surgenti.

Lu Ninu Fra Diáulu

Lu primu chi sparau

E a una di l'Agghiasoru

Lu pettu cci spunnau. 


\section{The Brothers Fra Diavoli}

Barefooted then, the other seven

Down the rope went sliding, And to the sands of the seashore

With long steps went striding.

Just a musket-shot away

A small boat they discover, And big Ninu, plunging in,

Swims the distance over.

He drew the boat up to the land,

Three men lay there sleeping;

They had a rifle close at hand,

But no watch were keeping.

Then and there the eight embarked,

Alongshore they went steering,

So swiftly, that in two hours' time

Gallina they were nearing.

All the eight there disembarked, And through the country scattered, Seeking clothes, and shoes, and arms,

Naked, cold, and tattered.

Up and down the streets they went, Such a tumult making,

That the people all about

In their beds were shaking.

From Palermo there marched out

A tremendous force, then:

Foot-soldiers, a regiment,

Police guards and horsemen.

Then Ninu Fra Diavolo

Fired a shot that tore through

All the crowd and struck by chance

A girl of Agghiasoru. 


\section{I64 Folk-Ballads of Southern Europe}

Pizzu di Corvu e Cifara,

Purtedda di Gallina,

Li so' prudigi vitturu

Di sira e di matina.

Cci dici la Giustizia

A li valenti frati:

-'Rrinnitivi, 'rrinnitivi,

Si no siti ammazzati!

Arrenni, 'Mbrociu, arrénniti,

Ca nun ti mulistamu!-

-L'omini nun s'arrenninu:

La vita cci lassamu!

Pitrè, Giuseppe: Canti Popolari Siciliani (Palermo, 1870-1), vol. ii., pp. r34-r 37 .

\section{GLI SCOLARI DI TOLOSA}

Sun tre giuvenin de scola, ch' a Tuluza völo andè.

Quand sun stait sül punt d'Tuluza

d'üna fia l'àn riscuntrè.

L'àn pià-la, l'àn ambrassà-la, tüti tre s'a '1 l'àn bazè.

Giüdise, savü sta növa,

tüti tre fa bin restè.

Ant ël fund d'la tur d'Tuluza

a l'à bin fà-je bütè.

Ël pi giuvo a dis a j'áutri :

-Quand sortruma nui da si?

Mi l'ài ün fratel an Fransa, s'a savéissa ch'mi sun sì, 
The Three Students of Toulouse 165

Gallìna, Corvu, Cifara,

Without a word of warning,

Were filled with awful deeds of blood,

By night, and noon, and morning;

Till the very Court sent out

Its terms of peace to tender:

"Yield, and we will save your lives;

Surrender now, surrender!"

"Yield, Ambrogio, yield at last,

You shall all be shielded."

"Not till death; brave men like us

Never yet have yielded!"

THE THREE STUDENTS OF TOULOUSE

(Piedmontese)

There were three gay young students

Went to Toulouse one day;

At Toulouse as they crossed the bridge,

They met a girl midway.

One seized her, one embraced her,

They kissed her every one;

The Judge sends straight to take them,

When he hears what has been done.

The Judge has sent to take them

Within that very hour;

And the poor lads are prisoned fast

In the depths of Toulouse tower.

Said the youngest to the others:

"When will they set us free?

In France I have a brother

If he knew would rescue me. 


\section{I66 Folk-Ballads of Southern Europe}

Faria de '1 fö a Tuluza,

'1 giüdise faria mürì.-

Üna veja da la fnestra

a stazia a riscutè.

A l'è andà dal signur giüdise,

sti descurs j'à raportè.

-O portè-me sì na piüma, üna piüma e ün föi d'papè,

Che vöi scrive na litrinha, a mia cà la vöi mandè.-

So fratel pia sta letra,

dëssigila e pöi la les;

Ant ël mentre la legia,

s'buta a pianze e suspirè.

A l'è andà ant la scüderia,

a caval a l'è muntè;

A Tuluza a s'büta a curre,

s'büta a curre e galopè.

Quand l'è stáit davzin Tuluza,

d'ün bun vei l'à riscuntrè.

-Dì-me 'n poc, o vui, brav'óimo,

che növe che m'êi da đè?

-Le növe sun váire bunhe,

sun nōve ch'a fan piurè;

J'è tre giuvenin de scola,

tüli tre devo ampichè.

-Dì-me 'n poc, o vui brav'óimo,

j'arivrai-ne ancur a temp? 


\section{The Three Students of Toulouse 167}

"He would set Toulouse a-fire,

He would have the Judge's head."

An old hag at the window

Listened to all they said.

And she is gone to my lord Judge,

And told it all again.

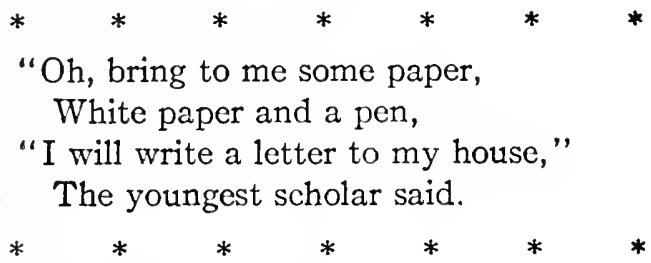

His brother took the letter,

He broke the seal and read;

And as he read the letter,

The brother wept and sighed;

Then hurried to the stables

To mount his horse and ride.

To Toulouse he goes spurring,

The horse it ran and ran;

As he came near the city,

He met a good old man:

"O good man, in the city, What is the news one hears?"

"The news is very evil, Would move your eyes to tears.

"They have taken three young students, They are hanging all the three."

"Oh, tell me, tell me, my good man, Am I in time?" cried he. 


\section{I68 Folk-Ballads of Southern Europe}

-Alamè 'n po pi la brila, che 'l caval va trop a lent.-

A l'à dà-je na sprunada, ch'a vulava cum' ël vent.

Quand l'è stàit sul punt d'Tuluza, j'ero già tüit tre pendent.

L'à dà man a la spadinha, testa al giüdise a j'a cupè.

- Ün l'era me frel pi giuvo, j'áutri dui cüzin german.

$O$ scapè vui áutre, done, cun i vostri pcit anfan;

Nui daruma 'l fö a Tuluza, brüzeruma pcit e grand.-

Nigra, C.: Canti Popolari del Piemonte (Torino, 1888), No. 4 A, pp. 5I-56.

\section{LES GÂS DE GÚERANDE}

Sont les gâs de Guérande Qui viv' en bons garçons, Falaridain' falaridon, Qui viv' en bons garçons, Falaridain' don don.

Ils sont bien vingt ou trente, Tous les trente-z-en prison, Falaridain' falaridon, Tous les trente-z-en prison, Falaridain' don don. 


\section{The Lads of Guérande}

"Let loose a bit your bridle rein

That seems the horse to bind."

The rider strikes his spurs again,

The horse flies like the wind.

But when he reaches Toulouse bridge,

All three are hanging dead.

He sets his hand upon his sword,

Strikes off the Judge's head:

"One was my youngest brother,

The two near kin!" he said.

"O fly, fly, all you women,

With little children, all!

We will set fire to Toulouse town,

And burn both great and small!"

\section{THE LADS OF GUÉRANDE}

(French)

It is the lads of Guerande, Their jolly life is done;

Falaridain' falaridon, Their jolly life is done, Falaridain' don don!

They are a score, and maybe ten more, In prison every one, Falaridain' falaridon, And in prison every one, Falaridain' don don! 


\section{I70 Folk-Ballads of Southern Europe}

Le plus jeune des trente

Savait une chanson,

Falaridain' falaridon,

Savait une chanson,

Falaridain' don don.

Tout' les dam' de la ville

Sont accourues au son,

Falaridain' falaridon,

Sont accourues au son,

Falaridain' don don.

Les prisons sont ouvertes,

Les prisonniers s'en vont,

Falaridain' falaridon,

Les prisonniers s'en vont,

Falaridain' don don.

Les uns s'en vont à Nantes,

Les aut' à Hennebont,

Falaridain' falaridon,

Les aut' à Hennebont,

Falaridain' don don.

Decombe, Lucien: Chansons Populaires: D'Ille- et-Vilaine (Rennes, 1884), pp. 319-320.

\section{SALGA}

Sus pe malul Dunărer̆

La perdéoa cu cânĭ reŭ

A Şalghiì a vădane

Este-o turmă de cărlanı̆

Păscută de opt cĭobanĭ,

Turma Şalghiì cea frumósă

Ca Şoĭmul de inimósă. 
The youngest of the thirty,

He knew a song to sing;

Falaridain' falaridon,

He knew a song to sing,

Falaridain' don don!

All the ladies of the town,

To hear came hurrying;

Falaridain' falaridon,

To hear came hurrying,

Falaridain' don don!

The prison doors are opened,

The prisoners all go;

Falaridain' falaridon,

The prisoners all go,

Falaridain' don don!

Some are gone to Nantes,

The rest to Hennebont;

Falaridain' falaridon,

The rest to Hennebont,

Falaridain' don don!

\section{SHALGA}

(Roumanian)

Where the Danube bank is high, The sheepfolds of Shalga lie;

Shalga's shepherds wake to fight

With the raiders at midnight;

Raiders fierce, and in their hands

Daggers sharp and leathern bands; 
La perdea 'n mleḑul nopţel

Nemerit-aŭ haľducey,

Nemerit-aŭ, năvălit-aŭ,

Paloşele zinghenit-aŭ,

Pe čobanĭ legatu-mĭ-aŭ,

Dulăi 'mpuşcatu-ĭ-aŭ.

Ear pe baciulul cel maĭ mare

Îl fereca şi maŭ tare

$\mathrm{Cu}$ cotele la spinare

De striga că reŭ îl doare:

"Căpitan Caracatucí

Vătăjel peste haĭducí!

Peste cincĭ sute şi cinč̆

Tot haĭducì de ceĭ voĭnici.

De-al̆ făcut vr'o dată bine,

Fă-ț̆ o milă şi cu mine

Şi 'mi deslégă braţele,

Reŭ me dor sermanele!"

Câpitanul se 'mblînđ̧ŭa,

Brațele-1̃ le slobođ̧uia.

Eară bacĭul cum scăpa,

Mâna 'n sînu-şi o băga

Bucium de aur căta,

Şi de treĭ ori bucĭuma,

Văile se resuna,

Frunḑele se clătina,

Salga 'n somnu-ĭ l'aự̆a,

Din somn Şalga se tređ̧ĭa,

La sócră-sa se ducea

Şi din gură aşa-1̆ đ̧icea:

"Malcă, măiculiţa mea!

N'auđ̣iş̣̂ tu buciumând 
Dogs lie dead upon the ground;

Every shepherd is fast bound.

The chief shepherd now they bind

Till his elbows meet behind,

Bind him in hard bands so fast

That he cries in pain at last:

"Captain Caracatuci, heed!

Thou who dost so proudly lead

Thy five thousand men and five,

If thou ever yet wast kind

To one wretched soul alive,

Pity me and bid unbind,

For I am in agony;

$\mathrm{Oh}$, in mercy set me free!"

Now for pity of his prayer,

Captain Caracatuci there

Bids them loose the shepherd's bands.

Scarcely have they freed his hands,

When the shepherd hastily

Draws his flute of cherry-tree

That lies hidden in his breast;

To its stops his lips are pressed,

Long and sweet the sound he brings;

Far away the valley rings;

On the trees the green leaves shiver,

And down in the Danube River

Waters boil and fishes leap.

Shalga hears across her sleep

That long cry the flute is making;

Shalga hears in sleep, and, waking,

To her old grandmother goes.

"Hark, oh, hark, grandmother dearest,

Far away thou surely hearest 


\section{Folk-Ballads of Southern Europe}

Şi văile resunând?

Nu stiı̆, maĭcă ciobani̊

Retăcit-aŭ cărlaniı̆,

Orĭ drumul aŭ retăcit, Orŭ hă̌duč ĭ-aŭ năvălit?"

Baba sócra respundea:

"Mergł te culcă fata mea,

De clobanŭ nu te 'ngrijĭa

C'aşa buciumumŭ ey cu dor

Când le 'ı̆ dor de casa lor."

Sócra bine nu sfîrş̧a,

Şalga ear că aự̆ia

Glas de buclum resunând,

Pân' în suflet resbătênd.

"He1! copiŭ, copiY argaţy!

Somnul dulce vol̆ lăsaţu,

S'un cal Iute'mŭ înşăuaţ̌,

Puneţi şaŭa bărbătesce,

Se încalec vol̆nicesce."

Ea pe cal se arunca

Şi spre Dunăre-alerga

Haulind şi chiuind,

Buzduganul învêrtind.

Cât haĭduciì o zărĭa 


\section{Shalga}

How the shepherd's flute is singing,

How the valleys all are ringing;

Dearest grandmother, who knows

What ill-fortune is befalling

To my shepherds? are they calling

To my sheep who go astray?

Have the shepherds lost their way

In the woods, or do they fight

With the raiders in the night?"

Said the mother: "Dearest, sleep,

For the shepherds and the sheep

Trouble thy sweet heart no more.

A shepherd of the Danube shore

Will flute all night for mere desire

To see again his own hearth-fire."

Ere she finished, came again,

Sad and long, the far flute's singing,

Setting all the valleys ringing,

Piercing Shalga's heart with pain.

"Wake, my men, my maids awake!

From your eyes sweet slumber shake!

Saddle my best horse for me

With man's saddle, soldierly,

For manlike to-night I ride."

To the horse she leaps, astride,

Toward the Danube bank she spurs,

Whirls her ax above her head,

Crying that fierce cry of hers.

Swift are all the raiders fled; 


\section{76 Folk-Ballads of Southern Europe}

Loc de fugă nu găsiă,

Eară \alga-ı̆ urmărĭa

Şi din gură-aşa răcnǐa:

“Ean astépt' astépt' astépta

Se luptăm la luptă dréptă

Căpitan Caracatucŭ,

Vătăjel peste hă̌ducĭ,

Peste cincĭ sute şi cinč̌

Tot haluducĭ de ceĭ volnnicy!

Stăy pe loc se ne'ntîlnim

Doă vorbe se grăim

Si'n arme se ne lovim,

Că me giur pe Dumneḑeŭ!

Se te 'nvăţ eŭ, fĕtul meŭ,

Cum se légă chobaniru,

Cum se pradă cărlanił."

Căpitan Caracatuč̆

Cetaş mare de haŭducĭ

Se ducea, ducea, ducea,

Nicĭ capul nu-ş̌ întorcea.

Salga-1̌ ič̆, Salga-1̆ colea,

Capul din fugă-ĭ tăǐa!

Capu 'n urmă remânea,

Trupu 'nainte fugĭa,

Sângele pîreŭ curgea,

Drumnul roş că se făcea!

Ci-că, mări de pe-atuncĭ,

Când vinŭ cete de haŭduč̆, Drumul lor nicĭ că greşescŭ,

Nič̆ că, ḑeŭ mă̌ nimerescŭ,

La perdéoa cu cânǏ reÎ

A Şalghiı̌ a vădanĕ,

De pe malul Dunăreı̆.

Alecsandri, Vasile: Poesi乞̌ Populare ale Românilor (Bucuresc", 1866), pp. 58-6r. 


\section{Shalga}

Space for flight they scarce can find,

Shalga comes so swift behind.

Captain Caracatuci hears

Shalga at his very ears,

Crying: "Wait, and let us fight!

Let us try our arms to-night!

"Captain Caracatuci, heed!

Thou who dost so proudly lead

Thy five thousand men and five!

Stay and change two words with me!

Stay and meet me soldierly,

If thou would'st be saved alive,

For by God in Heaven, I swear,

I will teach thee how they fare

Who rob my flocks and bind my men!"

Captain Caracatuci then,

As he listens to her cries,

Only flies and flies and flies;

Dares not turn his head for fear

Of Shalga there and Shalga here.

Shalga fiercely flying past

Strikes his head off as she goes;

Horse and body still ride fast,

Backward falls the severed head,

Like a stream his life-blood flows,

And the dusty road runs red.

Brother, since that night they say,

When the raiders come this way,

That they lose their road no more;

That they never linger by

Shalga's sheepfolds where they lie

High upon the Danube shore. 



\section{Biblical and Apocryphal Ballads}




\section{LA FUITO EN EGYPTO}

Un angi avertit Maria

Et Jause de s'enanar,

Jesus, Mario!

Et Jause de s'enanar,

Jesus, Maria!

Li a di: Jause, fai belo,

Fau plus gaire demourar,

Ai ausit uno nouvelo

Qu' Herodo vous fai cercar,

Voudrie faire mourir Jesus,

Esto nuech lou fau sauvar.

Quand la Viergi s'enanavo

Eme soun enfant au bras,

Rescontro bouyer brav'homme

Que samenavo soun blad:

-Digo-me, bouyer brav'homme,

$\mathrm{Tu}$ que samenes toun blad,

Fai la reg' un pau plus grande

Per pousque me l'y acclapar.

-N'en farai pas, belo damo, N'en farai pa 'n tau peccat.

-Vai-t'en cercar toun aurame

Et meissounaras toun blad. 


\section{THE FLIGHT INTO EGYPT}

\section{(Provençal)}

An angel warns Joseph and Mary,

They must arise and go,

$$
\text { Jesu! Maria! }
$$

They must arise and go,

$$
\text { Jesu! Maria! }
$$

He has said: "Make ready, Joseph,

You can no longer stay;

For news is come that Herod

Is seeking you to-day.

"This night you must be going,

To save the child from harm."

Then Mary Virgin rises

With her baby on her arm.

They meet with a good peasant,

A-sowing of his seed:

"Oh, tell me, my good peasant,

A-sowing of thy seed,

Canst thou not make the furrow wide,

To hide me in my need?"

"I cannot, my fair lady,

For that would be great sin."

"Go then and bring thy sickle,

And take thy harvest in." 


\section{Folk-Ballads of Southern Europe}

-Coumo pourrie-ti se faire Tout beou just l'ai samenat.

Lou brav'homme se reviro Soun blad es tout espigat;

N'en fouguet pas un quart d'houro Sieguet flourit et granat.

La premiero garbo que coupo

La Santo Viergi la liad'.

La secoundo garbo que coupo

La Santo Viergi s'es cachad'.

- Se les faus judious passavoun

Digo li la verita.

N'en fouguet pas un quart d'houro

Les faus judious ant passat:

-N'as pas vist passar Mario

Eme soun enfant au bras?

-Quand Mario n'en passavo Samenav' encar' moun blad.

Adounc, se disoun l'un l'autre, Aquot ero l'an passat.

Sant Jause prend la saumeto Quand les judious sount passats;

La Viergi se 1'y asseto Eme soun enfant au bras; 


\section{The Flight into Egypt}

"How should I reap my harvest?

My seed is scarcely sown!"

The peasant looks behind him,

And lo! the blade is grown;

And within a quarter-hour

' $T$ is ready to be mown.

The first sheaf of his cutting

The Holy Virgin bound;

Behind the second row of sheaves

A hiding-place she found.

"If the false Jews come riding,

The whole truth thou must speak."

Within a quarter-hour

The Jews come there to seek:

"Good man, has Mary passed here

With her little child to-day?"

"I was but sowing of my field

When Mary passed this way."

They say one to the other:

"That must have been last year."

Saint Joseph brings the little ass,

When the false Jews disappear;

The Virgin sits upon it,

With her baby at her breast; 


\section{I84 Folk-Ballads of Southern Europe}

S'en van dedins la valleio,

Mai quand sieguet su lou tard,

La Viergi n'es espuisado

De tant de camin qu'a fach;

Sant Jause duerbe la biasso

Mai se ly es plus ren trouvat:

Approuchem, diguet Mario,

Doou poumier que viou eilà.

-Mai les brancos sount tant hautos

Qui ly pourrai pas mountar.

La Viergi ausso ses menotos

Lou poumier s'es abeissat.

Quand ant set lou vin et l'aigo

Doou blanc roucas ant coulat.

D'eilà ven quatres grands laires

Que parlavoun que de tuar.

-Viergi, coumo pourrem faire

Per l'Enfant Jesus sauvar?

-V'aquit de bouissouns d'espignos

Fau vite se 1'y cachar.

Lou premier chivau que passo

Sente soun corps mautratat;

Lou segound chivau que passo

$N$ 'a lou ventre dechirat;

Lou troisieme se reculo,

L'autre fug' 'spouvantat. . . . 
They ride into the valley,

And the sun sinks in the west.

The Virgin she is faint for food,

With the long way they have come;

Saint Joseph looks into the bag,

But cannot find a crumb.

"Let us draw near," said Mary,

"To yonder apple-tree;"

"But all the branches grow so high,

I cannot reach," said he.

When Mary lifts her little hands

The apple-tree bends low;

And wine and water for her thirst

From out the white rocks flow.

There came along four robbers,

With wicked words and wild.

"O Virgin, what shall we do now,

To save the little child?"

"Now we must quickly hide him Behind that hedge of thorn."

The first horse leaped across the hedge, And all his breast was torn.

The second horse came springing,

His belly was all rent;

The third recled back in terror,

The fourth a-flying went. 


\section{86 Folk-Ballads of Southern Europe}

Per ana 'n terro d'Egypto

Un grand bouesc fau traversar;

Au mitan l'y a 'n mechant hoste, Que de gens qu' a massacrats!

A sa filho qu'es marauto, Sa fremo l'a sur les bras:

-Dounariats la retirado A de roumious fatigats?

- Intretz dedins la chambreto, Roumious, per vous repausar.

Dins la cour couelo fouent claro La Vierg'y tremp' un pedas.

Es benesido la maire Qu'a 'n tant bel enfant au bras.

Prend lou pedas de sa filho

Lou trempo dins lou bachas.

Et quand l'y a plegat sa filho Es lusento de santa:

Viam ben que siatz lou messio Que lou bouen Diou a mandat.

Pardounetz-nous nouestres fautos Vous que venetz nous sauvar, Jesus, Mario!

Vous que venetz nous sauvar, Jesus, Maria!

Arbaud, Damase: Chants Populaires de la Provence (Aix, 1864), pp. 235-240. 


\section{The Flight into Egypt}

To reach the land of Egypt

You traverse a great wood;

Midway is an inn with a wicked host,-

How he murders pilgrims good!

A little ailing daughter

His wife holds at her breast.

"Is there not here a chamber

Where pilgrims may find rest?"

"Enter this chamber, pilgrims, And rest you without fear."

And Mary dips a swaddling cloth

In the courtyard fountain clear.

"Now blessèd is the mother

Who bears a child so fair!"

The sick child's mother dips a cloth

In the same water there;

She wraps it round her baby,

And it shines with health straightway.

"Oh, we see thou art Messiah,

Whom God hath sent to-day!

"Oh, pardon, pardon all our sins,

Thou who dost come to save,

Jesu! Maria!

Thou who dost come to save,

Jesu! Maria!" 


\section{88 Folk-Ballads of Southern Europe}

\section{MARIO MADALENO}

Mario Madaleno,

La pauro peccairitz,

S'en vai, de pouert' en pouerto,

Cercar Diou Jesus-Christ.

Pass'à-n-uno capelo, Jesus 1'y ero dedins,

Doou ped piqu' à la pouerto:

"Jesus, venetz durbir."

Sant Jean di à Sant Peyre,

"Regardo qu es aquit."

"Es Marie Madaleno

La pauro peccairitz."

"Mario Madaleno

Eici que venes far?"

"Seignour Diou, moun bouen paire,

Me vene counfessar."

"Ah! digo, Madaleno,

Ah! digo tes peccats;"

"N'ai tant fach et fa faire

Les pourriou pas noumbrar;

La terro que me pouerto

Me deurie plus pourtar,

La vill' ounte siou nado

Se deurie proufoundar." 


\section{MARY MAGDALENE}

(Provençal)

Poor Mary Magdalene,

Who lives a life of sin,

From door to door goes seeking

If Jesus stay within.

She passes by a chapel,

And there indeed is $\mathrm{He}$;

Then with her foot she beats the door:

"Lord, open unto me!"

Saint John says to Saint Peter:

"See who would enter in."

"T is Mary Magdalenè,

Who lives a life of sin."

"O Mary Magdalene,

What art thou doing here?"

"I come to make confession,

Lord God, my Father dear!"

"Speak, Mary Magdalene, And all thy sins tell true."

"I have done and caused so many,

I cannot count them through.

"The very ground I stand on, $\mathrm{Oh}$, it should swallow me;

The very town where I was born

Should sink into the sea!" 


\section{I9o Folk-Ballads of Southern Europe}

"Sept ans souto la baumo

Te foudr' ana' estar."

Au bout de sept anneios

Jesus-Christ l'y a passat.

"Mario Madaleno,

De que tu n'as viscut?"

"De racinos sauvageos

Et n'ai pas toujou' agut;"

"Mario Madaleno,

De qu' aiguo n' as begut?"

"N'es d'aiguo trebourado

Et n'ai pas toujou' agut."

"Seignour Diou, mouen bouen paire,

Mes mans voudriou lavar;"

Jesus piqu' à la roco,

D'aiguo n'en a raiat.

"Ai! belo man blanqueto,

Blanco coumo lou lach;

Fresco coumo la roso,

$\mathrm{Qu}$ t'a vist et te vei!"

"Mario Madaleno, Tournes dins lou peccat, Sept ans as resta 'n baumo, Sept ans l'y tournaras."

"Seignour Diou, moun bouen paire, Coumo pourrail'y'star?"

"Ta souere Santo Martho

T'anara counsoular; 
"Seven years in yonder cavern,

O Mary, thou must stay."

And when the seven years were done,

Christ Jesus passed that way.

"O Mary Magdalenè,

Tell me, how dost thou thrive?"

"I eat the wild roots of the wood, And scarcely keep alive."

"O Mary Magdalenè, What water dost thou drink?"

"A water scant and muddy,

Until my tongue doth shrink.

"O Lord God, my good Father, I long to wash my hands." Then Jesus strikes fresh water From the rock near which $\mathrm{He}$ stands.

"Ah, lovely little white hand, Fresh as a rose might be! All white and fresh as morning milk, Oh, thou art good to see!"

"Ah, Mary Magdalenè, Now dost thou sin again; Seven years hast thou dwelt in this cave, Seven more thou must remain."

"Dear Lord, here in this cavern, How can I longer stay?" "Saint Martha, thy good sister, Will comfort thee each day. 


\section{Folk-Ballads of Southern Europe}

"La blanco couloumbeto

Te pourtar 'à dinar,

Et les auceous que pitoun

T'anaran abeurar."

"Seignour Diou, moun bouen paire, Me l'y fetz plus tournar,

Des larmos de mes uelhs

Les mans me lavarai,

"Des larmos de mes uehls

Les peds vous lavarai,

Des chevus de ma testo

Vous les eissugarai.'

Arbaud, Damase: Chants Populaires de la Provence (Aix, I862: not in 1864 ed.), pp. 64-67. Also BrIz y Saltó:

Cansons de la Terra (Barcelona, 1866-7), vol. ii., pp. 102-103.

\section{SANTA MADALENA}

Marta 's lleva demati

á sermò se ne's anada,

quan tornava de sermò

se'n va á casa sa germana.

Dalt del cel,

dalt del cel tindrém posada, dalt del cel.

Madalena's pentinava

$a b$ una pinta daurada, mentres que se 'n pentinava

ja n'arriba sa germana.

"Me dirias Madalena

si has anat á missa encara?"

"No hi he anat, germana, no,

ni en tal cosa no hi pensava." 


\section{Saint Mary Magidalene}

"The white dove of the forest

Each day will fetch thee food;

The little birds that peck about

Will bring thee water good."

"O Lord God, my good Father, Send me not back again!

I '11 wash my hands with tears that fall

From out my eyes like rain;

"With tears from my eyes falling

I will wash white and fair

Thy blessèd feet, $O$ Jesus,

And dry them with my hair!"

\section{SAINT MARY MAGDALENE}

(Catalan)

Martha rose and went to mass,

Very early in the morning;

After service she passed by

Her sister's house, homeward returning.

Up in Heaven.

Up in Heaven shall be a dwelling,

Up in Heaven.

Magdalenè combed her hair

With a comb all gilded bright;

Just as she is combing it,

Her sister Martha comes in sight.

"Have you been to mass to-day?

Tell me truly, Magdalene."

"I 've not even thought of it;

No, indeed, I have not been." 


\section{I94 Folk-Ballads of Southern Europe}

"Veshi, veshi, Madalena, quedarás enamorada, que hi predica un jovenet un ángel del cel semblava."

Madalena se 'n va á dalt á posars' las sevas galas;

se 'n posa los anells d' or, las manillas y arracadas, y la prenda del or fi al seu cor se la posava, y tambè lo manto d' or que per terra arrossegava.

Madalena se n' hi va

ab sos criats y criadas. Al se' al entrant de la sgleya se mig gira á una criada. "Válgam Deu, quin jovenet, llástima que sia frare!"

A la porta de la sgleya deixa als que l' acompanyavan.

Sgleya amunt, sgleya avall no troba lloch hont posarse;

per sentir millò' '1 sermò sota la trona 's posava.

Lo primer mot del sermò per Madalena ja anava.

Las paraulas que sentia totas Io cor li tocavan. 


\section{Saint Mary Maǵdalene}

"Go, go, Magdalenè, go!

You will surely fall in love,

For the youth who preached is like

An angel come from Heaven above."

Magdalenè went upstairs

To put on her jewels gay;

Rings and bracelets all of gold

And earrings she put on that day;

A clasp she wore above her heart

Of gold the finest ever found,

And her mantle trimmed with gold

Trailed behind her on the ground.

Magdalenè went along

With many a page and many a maid;

At the entrance of the church,

To a maid she turned and said:

"That youth, good God! it is a pity

To make a friar of such as he!"

At the great door of the church

She dismissed her company.

Up the church and down the church, She goes and cannot find a seat;

So under the pulpit she sits down,

Right below the friar's feet.

At the first word that he spoke

Magdalenè gave a start;

Every word she listened to

Touched her at her very heart. 


\section{I96 Folk-Ballads of Southern Europe}

Quan son al mig del sermò

Madalena cáu en basca.

"No 't desmayis Madalena

que lo sermò ja s' acaba."

Ja se 'n treu los anells d'or,

las manillas y arracadas,

y la prenda del or $f i$

als seus peus se la posava.

Acabat qu' es lo sermò

Madalena se 'n tornava.

A la porta de la sgleya

un penitent hi trobava.

"Me dirias, penitent, ahont es aquell bon frare?"

“A la taula n' es Jesus, n' es allá que dina encara."

Madalena se n' hi va sota la taula 's posava.

Los ossos que Jesus llensa

ella los arreplegava.

Ab llágrimas dels seus ulls

los peus de Cristo rentava

y ab la sua cabellera

Madalena 'ls aixugava.

Bon Jesus se 'n va adonar

promptement li preguntava:

"Que buscas tu, Madalena, que buscas sota la taula?" 


\section{Saint Mary Magdalene}

When the sermon was half done,

She fell fainting on the floor;

"He 'll soon finish, Magdalene,

Don't be frightened any more."

She has taken her rings of gold,

Her earrings and her bracelets all,

And her clasp of finest gold:

At his feet she lets them fall.

When the sermon was all done,

Magdalenè turned and went

To the great door of the church,

Where she found a penitent.

"Penitent, where is he gone?

Tell me truly, if you 're able."

"Jesus has not dined as yet;

$\mathrm{He}$ is seated at the table."

Magdalenè went along;

Underneath the table crept, And the bones that Jesus dropped

With her hands together swept.

With the tears from out her eyes

The feet of Christ she washes there;

She has washed them with her tears,

And she has dried them with her hair.

The good Jesus looks on her,

And he asks her, gently speaking:

"What dost thou seck, Magdalene,

Underneath the table seeking?" 


\section{Folk-Ballads of Southern Europe}

"Busco per aquí á Jesus

si voldria confessarme."

"De que 't confessarás tu?

De que 't confessarás ara?"

"De que me 'n confessarè?

De las mas culpas passadas."

"La penitencia que 't dò

set anys en una montanya

menjant herbas y fenolls, menjant herbas amargantas."

Acabat de los set anys

Jesus per allí passava.

"Álsat, álsat Madalena

que ja ne estás perdonada."

Madalena se n' alsat

cap á casa se n' tornava.

Quan va ser á mig camí

troba una font de aiga clara.

Ab l' aiga de aquella font

las sevas mans se 'n rentava.

“Ay, mans qui 'us ha vist y 'us véu

com ne son desfiguradas!"

Ja sent una veu que diu:

"Madalena n' ets pecada."

"Angel meu si n' hi pecat

penitencia 'm siga dada."

"Torna, torna Madalena

set anys en una montanya 


\section{Saint Mary Magdalene}

"It is Jesus I seek here,

To confess myself to-day."

"What is it thou would'st confess?

What would'st thou confess, now, say?"

"What would I confess? Alas!

All the old sins I have done!"

"On a mountain thou must live

In penance till seven years are gone,

"Eating grass and fennel there, Eating bitter herbs and grass."

When the seven years are gone, Jesus by that way doth pass:

"Now thy sins are all forgiven, Rise up, Magdalene, arise."

Magdalene arises then, And straightway toward her house she hies.

Half way on the road she sees A spring of water clear and bright;

In the water of the spring

Her two hands she washes white.

"O my hands, how you are spoiled! Oh, to see you and have seen!"

Then she hears a voice that cries:

"Thou art a sinner, Magdalene!"

"Angel mine, if I have sinned, Some one should a penance give." "Turn back, turn back, Magdalene; Seven years on the mountain live, 


\section{Folk-Ballads of Southern Europe}

menjant herbas y fenolls, menjant herbas amargantas."

Acabats los catorz' anys

Madalena ja 'n finava.

San Joseph n' era '1 fuster que la caixa li clavava,

San Joan n' era '1 florista que li feya la enramada, los ángels li feyan llum, la Verge 1' amortallava, y ab gran cantarella al cel cap al cel se la empujavan.

Briz y Saltó: Cansons de la Terra (Barcelona, 1867), vol. ii., pp. 95-104.

\section{LA SAMARITANA}

Que ditxosa fou

la Samaritana

que anant á la font

á Jesus trobava.

Esposa del cel

volguda y aymada!

Jesus li diguè:

"Si 'm vols donar aiga."

"No per cert senyor

que 'm costa de traure."

"Be me 'n donarias

si t' endevinava." 


\section{The Samaritan Woman}

"Eating grass and fennel there, Eating bitter herbs and grass."

When the fourteen years are gone, Magdalenè's soul doth pass.

Saint Joseph was the carpenter, And the coffin nails he drove;

Saint John he was the gardener, And a wreath of flowers he wove;

Angels bore the lights for her;

The Virgin laid her in her shroud; Straight to Heaven they carried her, In a chorus singing loud:

Up in Heaven, Up in Heaven shall be a dwelling, Up in Heaven!

\section{THE SAMARITAN WOMAN}

(Catalan)

The Samaritan woman (such good fortune befell)

She found Jesus sitting one day at the well.

$O$ bride of Heaven!

Desired and beloved!

Jesus said to her: "Woman,

Give me drink of this water."

"Oh, no indeed, Señor,

'T is too hard work to draw it."

"Thou wilt give me to drink,

I am sure, of this water,

If I tell thee thy fortune,

All thy life as I saw it." 


\section{Folk-Ballads of Southern Europe}

"Si me 'n endivináu, jo 'us darè de 1 ' aiga."

"Ne tens tres galants

tots sentats á taula,

lo un se 'n diu Pere,

1' altre se 'n diu Jaume,

1' altre Salvador

que tot lo mon salva."

"Bevéune Senyor

bevéune de l' aiga."

"No vull aiga no

que vull la teva ánima."

Ella agafa 'ls cantis

y á casa tornava.

Troba '1s tres galants

a dins de sa casa.

lo un ne fa foch,

l' altre n' escombrava,

1' altre es pèl camí

que me la esperava.

Li diu lo mes xich

"Dona qu' ets tardada?"

"Martxéune galants

martxéune de casa,

un jove he trobat

que $m$ ' ha il-luminada."

"No sia 'l dimoni

que t' haja tentada."

"No era 'l dimoni

que un ángel semblava." 
"I will give you the water,

Divine if you 're able."

"Three lovers thou hast

Who sit at thy table;

The first is called James,

The second is Peter,

The third is called Saviour,

For the world he is saving."

"Oh, drink again, Señor;

No water is sweeter."

"No water I crave,

Who for thy soul am craving."

She filled all her jars,

To her own house returning;

There she found the three lovers,

The house they were keeping.

The first of the lovers,

The floor he was sweeping;

The second was busy

To keep the fire burning;

But the third lover stood

In the roadway and waited.

He called out, the youngest:

"Why are you belated?"

"Go away, O my lovers!

Depart from my dwelling!

I have found a strange youth,

My whole life he 's been telling."

"' $\mathrm{T}$ is most likely a devil,

To tempt you to sinning!"

"There was never a devil

So angelic and winning." 


\section{Folk-Ballads of Southern Europe}

Ella pren los cantis

y á la font tornava.

Al ser á la font

á ningú hi trobava.

Ella pren los cantis

y s'e 'n torna á casa

al se' á mig camí

una creu trobava.

Ne cáu de genolls

ab las mans plegadas

y ab aquella creu

de tot cor s' hi abrassa:

ab una pedreta

los pits se trucava.

Li crida una veu:

"Ja estás perdonada."

Briz y Saltó: Cansons de la Terra (Barcelona, 1867), vol. ii., pp. 205-210.

\section{LOU MARRI RICHE}

La maire de diou plouro

dessus ses blancs ginous,

Soun cher fiou li demando:

"ma mero qu' avetz vous?"

“Iou n' en ploure des paures

que n' en moueroun de fam."

"Plouretz pas plus, ma maire,

les riches li daran."

"Un pau d' oumoin', ô riche, au noum de Jesus-Christ."

"Lou bouen Diou vous assiste

de pan iou n' en ai gis." 
Once more to the fountain

The jars she has taken;

But no one she finds there,

The place is forsaken.

She lifts up the jars,

And homeward is bound, then.

About half-way along,

A stone cross she found, then.

She falls down on her knees,

Her clasped hands upholding;

With both arms the cross

To her heart she is folding.

As she beats with a stone

On her breast sad and burdened,

She hears a voice crying:

"Behold! thou art pardoned!"

\section{THE WICKED RICH MAN}

(Provenģal)

The Mother of God is weeping

Underneath her white coverchief.

Her dear Son asks her: "Mother,

Tell me, what is your grief?"

"My Son, I weep for the beggars;

They die of hunger, " she said.

"Now weep no more, my mother;

The rich will give them bread."

"Give bread for alms, O rich man!

In the name of Christ, I pray."

"Now may the good God help you!

I have no bread to-day." 


\section{Folk-Ballads of Southern Europe}

"Donnetz me les briguctos que vos toumboun davant;"

"Les briguetos que toumboun n'en soun per mes chins blancs."

Dedins la quinzenado eou n' en ven a mourir, Doou ped piqu' à la pouerto doou Seignour Jesus-Christ.

Sant Jean di à Sant Peyre: "Regardo qu es aqui;"

" $N$ ' en es lou marri riche, voou intra 'n Paradis."

"Alors tu dounc demando ce qu'a fa' à soun pays, s' à fach l' oumoin' es paures vesti les maus vestits."

"Ai pas fach l'oumoin' es paures vesti les maus vestits;

mai se iou retournave en aqueou plan pays,

" $n$ ' en caussariou les paures n' en vestiriou les nuds."

"Lou fourie far quand l' y eres mai aro 1' y sies plus."

En plourant se retonerno $n$ ' en toumbo dins l' infern.

"Hai! paure iou! sur terro n' en ai pas proun souffert, 
"Give me the little crumbs, then, "That are scattered on the ground."

"The little crumbs that are scattered, They are for my white hound."

Within a fortnight after,

The wicked rich man died;

He beat at the door of our Lord Christ,

And to open it he tried.

Saint John says to Saint Peter:

"See who stands and cries."

"It is the wicked rich man;

He would enter Paradise."

"Go ask him what he did living, Below in his own country,-

If he used to clothe the ragged, And give alms in charity."

"I did not clothe the ragged, Nor give alms in charity;

But if I might return there once,

Below, to my own country,

"Oh, I would clothe the naked, And the beggars should not lack."

"You should have done it there at first, For you never can go back."

He turned him away then, weeping, And sank to the depths of Hell; "Oh, on the earth I knew no pain! Poor me! I lived too well! 
208 Folk-Ballads of Southern Europe

"aviou couissin de plumo,

mataras de velours,

aro n' en ai un rouge

que brulo nuech et jour."

Arbaud, Damase: Chants Populaires de la Provence (Aix, 1862), pp. 53-58. Also BRIz y Saltó; Cansons de la Terra, vol. ii., pp. 240-24I.

\section{LO MAL RICH}

Lo mal rich s' está en finistra-passa un pobre pelegri: li diu demanant almoyna-si es que '1 vol afavorir.

Jesus y Maria

preguéu per mi!

-D' aquest pa que déu als gossos-si me 'n desseu un bocí.

- Mira pobre si t' hi baixo-te'n farè fugir d' aquí, te farè abordar pèls gossos-si trigas gayre á fugir."

No triga l' espay d' una hora-que 'l pobret ja va morir.

Truca á las portas del Cel,- del Cel y del Paradís. Jesus ne diu á Sant Pere:-"Pere, mira qui hi ha aquí."

-Ay, Senyor! n' es aquell pobre-que ' 1 mal rich deixá morir. 
"I had pillows all of feathers, On a velvet couch I lay, But now I shall have a fire That burns by night and day!"

\section{THE WICKED RICH MAN AND THE BEGGAR}

\section{(Catalan)}

The rich man looks from the window;

A poor pilgrim passes by;

For alms he comes a-begging,

If the rich will have charity.

Jesus and Mary,

Pray, oh, pray, for me!

"For two whole days together,

Not a crumb to eat have I."

"If I come down, you beggar,

I wager your feet will fly;

"I 'll make you leave in a hurry;

You won't wait for me if you 're wise!"

It is not quite an hour

Before the beggar dies.

He knocks at the gates of Heaven, Of Heaven and Paradise.

Then Jesus says to Saint Peter:

"See who comes the gates to try."

"Ah, Señor, it is the beggar

That the rich man left to die." 


\section{1o Folk-Ballads of Southern Europe}

-Obrali las portas, Pere,-las del Cel y Paradís."

No triga l'espay d' una hora-que lo mal rich va morir.

Truca á las portas del Cel,--del Cel y del Paradís.

Jesus ne diu á Sant Pere:- "Pere, mira qui hi ha aquí."

-Ay, Senyor! n'es lo mal rich-qu' al pobre deixá morir.

-Táncali las portas, Pere,--las del Cel y Paradís, que se'n vaja mes avall-que no li dirán que no, eixirán deu mil dimonis-que ' 1 farán patir de mort, malehirá pare y mare-y qui l' ha portat al mon, malehirá padrí y padrina-y qui '1 ha porta'á las fonts,

Malehirá '1 capellá-que li feu la creu al front, Malehirá l'escolá-que li feu llum ab l'hatxò.

Briz y SALtó: Cansons de la Terra (Barcelona, 1867), vol. ii., pp. $235^{-2} 41$.

\section{IL FIGLIO PRODIGO}

-Signuri Patri,-_o mi nni voggh'jiri, Vogghiu guriri-la mè libirtà.- 


\section{The Prodigal Son}

"Oh, open the gates wide, Peter,

Of Heaven and Paradise."

It is not quite an hour

Before the rich man dies.

He knocks at the gates of Heaven,

Of Heaven and Paradise.

Then Jesus says to Saint Peter:

"See who comes the gates to try."

"It is the wicked rich man

Who let the beggar die."

"Oh, shut the gates fast, Peter,

Of Heaven and Paradise,

And let him go below there;

They will not say him nay;

There will be two thousand demons

To torture him night and day;

"He will curse his father and mother, Who gave him life and limb,

Godfather and godmother,

To the font who carried him;

"He will curse the priest whose fingers

The cross on his forehead signed;

He will curse the school and the learning

That kindled light in his mind."

\section{THE PRODIGAL SON}

(Sicilian)

"O my dear father, Away I am going,

I long to be knowing

The joys of liberty." 


\section{Folk-Ballads of Southern Europe}

-O Figghiu, adunca-te' li rinari;

'Ttenni a scialari-pi tò libirtà.

Pensa ogni passu-a l'affrittu 'i tò patri, Pensa a tò matri-e a li frati tò'.-

Scinni la scala-cu granni primura, L'amici llura—si trovanu ddà.

-Amici mei,_alleghiramenti!

Manu ê strumenti-'i rinari su' ccà.

Prestu accattamu一vinu e pastizzi!Vennu li sbrizzi:-'rinari 'un cc'è cchiù.

Li beddi amici-si l'hannu purtatu, L'hannu spurpatu-'nta chidda cità.

Quannu l'amici-lu vittiru nuru, Lu lassaru sulu-'nta chidda cità.

-Amici mei,- - pirchì mi lassati? M'abbannunati-pirchì 'un aju cchiù! 


\section{The Prodigal Son}

"Son, take thy money,

Take it and squander;

Where thou wilt, wander;

Have thy liberty.

"At each step remember

The grief of thy mother,

The love of thy brother, And thy father's care."

He went down the staircase,

Went hurrying madly,

Where his comrades all gladly

Waited him there.

"O my good fellows, Here 's plenty of money; We 'll have wine and honey, And music till dawn.

Set hands to the lute here,

We 'll sing and drink faster!"

But soon comes disaster,

The money is gone!

Oh when his brave comrades

His money had wasted, To see how they hasted

Away from the place!

They left him all naked,

These friends of fair weather,

They hurried together,

Left him in disgrace.

"O my friends, my good fellows,

How can you hurt me?

Do not desert me

In this lonely place!" 


\section{I4 Folk-Ballads of Southern Europe}

Lu lucanneri-p'esseri aggiustatu

Già l'ha spugghiatu—cu crurilità;

E di la scala-dipoi lu sdirrupa,

Pigghia la scupa,-l'ammutta di ddà.

- Signuri patruni,--vuliti un garzoni, Cci rati 'na gnuni;--adduari si vò;

Un tozzu di pani-un giru di casa, Ca iddu'un s'arrasa:-cuntenti si stà.

-Guardari hai li-porci-agghianni ha' a manciari. Si cu mia stari,-_figghiuzzu vò' tu.-

Supra'na petra-si misi a pinsari, A larimari-un figghiu di Rè!

E lu ricia-cu chiantu ruttu:

-A ch'è ridduttu - un figghiu di Rè!

Aju un patruzzu-ch'è tantu binignu, Ca'un sugnu dignu,-'un lu meritu cchiù! 


\section{The Prodigal Son}

There came the innkeeper:

Accounts must be reckoned

In this very second

For these great affairs;

Angry and cruel,

He strode from the room then,

And seizing the broom then,

Swept the boy downstairs.

"O my good master,

I have not a shilling.

Now would you be willing

To hire me to-day?

For dry bread and water

I 'll wait at the house here;

As still as a mouse here,

Contented I 'll stay."

"Stay then, my fine boy,

The swine you 'll be minding,

And hard fare be finding,

Winter and spring."

His tears they were falling,

And on a stone sinking,

He set him to thinking-

The son of a king!

He said to himself there:

"What life thou art leading,

These swine to be feeding,

Thou, son of a king!

"I have a dear father,

So gentle and kindly;

I left him so blindly,

Deserve him no more! 


\section{Folk-Ballads of Southern Europe}

Siddu cci vaju,-mi vastunia, E mi castia;-nun cci vaju cchiù!-

Pi ghiri a biriri-sò patri divinu, Si misi 'n caminu-cu gran piatà.

Lu patri misu-a lu barcuni Misu appujuni.-Mè figghiu unn'è?

Sò patri misu-cu 'u sò ucchialinu: -Figghiu mischinu,-'un cci spunti cchì̀!

Ea s'è mè figghiu-chissu ca veni!Chissu ca veni-'un si canusci cchì̀!

Quannu lu vitti-allura spuntari Si misi a grirari-di ccà e di ddà:

-Amici mei,-me' sirvienti, Alleramenti :-mè figghiu è ccà! 


\section{The Prodigal Son}

If I should go to him,

Perhaps he will beat me,

Or angrily meet me,-

I 'll go there no more!"

Yet to see his dear father,

Homeward returning

With sorrow and yearning

He starts out to run.

(

* *

*

*

The father is sitting

In his terrace off yonder,

To sigh and to wonder:

"Where is my son?"

The father is watching,

With a glass he is spying:

"Let him thrive or be dying,

$\mathrm{He}$ comes here no more!

If that were he running,

If he came to ask pardon, This old heart I 'd harden, And show him the door!"

The father has seen him

Far off appearing,

He watches him nearing,

Shouts hither and yon:

"Look forth, O my friends, now!

My people! My pages!

Be quick, earn your wages!

This is my son! 


\section{I 8 Folk-Ballads of Southern Europe}

Prestu jttamu-ssi 'mbrogghi fitenti. Su' puzzulenti-pi un figghiu di Rè; Facemu un bagnu-priziusu e finu, Ch'è sangu divinu,- - ch'è figghiu di Rè!-

PirRè, G.: Canti Popolari Siciliani (Palermo, 1871), vol. ii., pp. $340-343$.

\section{S. JAUME DE GALICIA}

$N^{\prime}$ era un pare y una mare

$y$ un fill qu 'ell dos tenian, feren una prometensa

á sant Jaume de Galicia d' anarhi gayató en má

y rosaris á la cinta.

Quan foren un poquet lluny

un poquet lluny de la vila

encontaren un hostal

que hi havia una fadrina.

La fadrina del hostal

dihuen que n' era atrevida.

Diu la fadrina al romeu:

"Dóm un bes per cortesia."

"No 'u mana la lley de Deu,

ni sant Jaume de Galicia."

La fadrina del hostal

va dir que s' en venjaria.

$N^{\prime}$ agafa una tassa d' or

ab que ' 1 seu oncle bevia 
"Make haste to strip from him

All this vile clothing,

It fills me with loathing,-

The son of a king!

Now make his bath ready, And rich garments worthy Of his noble birth,- -he Is son of a king!"

\section{SAINT JAMES OF GALICIA}

(Catalan)

A father and a mother,

And with them their young son,

To Saint James of Galicia

On pilgrimage are gone,

With rosaries at girdle,

And pilgrim staffs in hand;

A short way from the city

They see a tavern stand;

And watching for their coming,

The damsel of the place Speaks to the boy pilgrim:

"A kiss, sir, of your grace."

"Nay, by Saint James, and by God's law,"

The pilgrim answered sage,

"He must not kiss a maiden,

Who goes on pilgrimage."

The damsel of the tavern

Straightway on vengeance thinks;

She takes the golden goblet

From which her uncle drinks, 


\section{Folk-Ballads of Southern Europe}

y la fica á lo sarró

mentre 'l pelegri dormia.

Quan es hora de dinar

la tassa d' or no hi havia.

En sent hora de sopar

la tassa d' or no's tenia.

La fadrina del hostal

diu que 'l fadrí la tenia.

"Si jo tinch la tassa d' or

que 'm penjin al mateix dia."

Li registran lo sarró

y la tassa d 'or hi havia.

La justicia rigurosa

lo va penjá al mateix dia.

Pero son pare y sa mare

no deixan de fer sa via.

Quan ne son á la tornada

lo seu fill veure volian.

Diu la romera al romeu:

"Jo per allí hi passaria."

“No passéu per'lli muller

que '1 dolor vos revindria."

“'Revení'ó no revení',

resarè un' Ave Maria." 
The precious golden goblet

That for himself he keeps;

She hides it in the wallet,

While the young pilgrim sleeps.

When comes the hour for dinner,

They nowhere find the cup;

They search for it all vainly,

When comes the hour to sup.

Says the damsel: "That young pilgrim

Has stolen the cup away."

"If I have stolen your golden cup,

Hang me this very day!"

Now they have searched the wallet, And found the cup of gold;

The Justice of the city

$\mathrm{He}$ is severe and old.

He has bidden them hang the pilgrim

Upon that very day.

The father and the mother

Go sadly on their way.

But when they are returning,

The mother needs must see

Her boy's body where it hangs

Upon the gallows tree.

"Oh, go not that way, woman,

Thy grief will come again."

"Let it come or not come, I will go

And whisper Aves twain." 


\section{Folk-Ballads of Southern Europe}

Aixis qu' ella se hi costa veu que ' 1 seu fill se movia.

"Com ets viu lo meu fillet com ets viu ab tants de dias?"

"No tinch d' esser viu ma mare

ab tan bona companyia?

Sant Jaume me tè pels peus

y la Verge per la cinta,

y lo cap lo Esperit sant

que il-lumina nit y dia."

Anáusen á cal Veguer,

á cal Veguer de la vila;

trobaréu que está dinant

menjantse gall y gallina,

quan arribaréu allí

li diréu ab cortesia:

"Dèu lo guart senyor Veguer

á vosté y la companyia.

Vaja á despenjá 'l meu fill

qu' 'encara está plé de vida."

"Fugíu d' aquí dona boja

no'm digáu tal bojería

que tan es viu vostre fill

com aquest gall y gallina."

Lo gall se posa á cantá',

la gallina al plat ponia.

Aixó es miracle del cel

miracle que Deu envia.

Despenjaren a l' infant

y penjaren la fadrina.

Briz y CANDi: Cansons de la Terra (Barcelona, 1866), vol. i., pp. 67-74. 


\section{Saint James of Galicia}

Now when the pilgrims reach the place,

$\mathrm{Oh}$, wonderful to see!

The boy's body stirs with life

Upon the gallows tree.

"How comes it, O my son, my son!

"That still thou art alive?"

"Mother, in such good company,

Well may I live and thrive.

"The Virgin holds my body's weight,

Saint James my feet," he said;

"The Holy Ghost, by night and day,

Is holding up my head."

Father and mother go in haste

To seek the mayor then;

They find him sitting down to dine

Upon a cock and hen.

"God save thee, Master Mayor,

And all thy company!

Take down my son who is alive

Upon the gallows tree."

"Away, you crazy woman!"

The mayor shouted then:

"Your boy is as much alive

As are this cock and hen!"

And straight the hen has laid an egg,

The cock he is a-crowing!

A blessèd miracle it is,

Of God Almighty's showing.

To take the boy pilgrim down

The mayor hurrièd;

But the damsel of the tavern

They hanged her in his stead. 
Ballads of the Supernatural 


\section{LO COMPTE ARNAU}

La comptesa está sentada viudeta igual!

La comptesa está sentada al seu palau.

Se li presenta á la cambra válgam Dèu val!

Se li presenta á la cambra lo compte Arnau.

Tot cobert de rojas flamas ay quin espant!

Tot cobert de rojas flamas valgám Dèu val!

"Per hont heu entrat vos ara compte 1' Arnau?

Per hont heu entrat vos ara? válgam Dèu val!"

"Per la finestra enreixada muller leal, per la finestra enreixada viudeta igual!"

"Tota me 1' hauréu cremada compte l'Arnau, tota me l' hauréu cremada válgam Dèu val!" 


\section{COUNT ARNOLD \\ (Catalan)}

The Lady Countess she is sitting,-

Woman most true!

She is sitting in her palace,

All the night through.

There has come into her chamber,-

Help, God of might!

There has come into her chamber

Arnold, her knight.

With red flames all covered over-

Oh, fearful sight!

With red flames all covered over-

Help, God of might!

"How did you enter at this hour,

Arnold, my knight?

How did you enter at this hour?

Help, God of might!"

"I entered at the grated window,

Woman most true;

I entered at the grated window;

Loyal are you."

"You are scorching me all over,

Arnold, my knight;

You are scorching me all over;

Help, God of might!" 
228 Folk-Ballads of Southern Europe

"Tan sols no 'us la he tocada muller leal,

tan sols no 'us la he tocada viudeta igual!"

"Qu' es aixó que 'us surt del cap compte 1' Arnau?

Qu' es aixó que 'us surt del cap? válgam Dèu val!"

"Malas cosas qu' he pensadas muller leal,

malas cosas qu' he pensadas viudeta igual!"

"Qu' es aixó que 'us surt pèls ulls compte 1'Arnau?

Qu' es aixó que'us surt pèls ulls? válgam Dèu val!'

"Son las malas 1lambregadas muller leal,

son las malas llambregadas viudeta igual!"

" Qu' es aixó que'us ix pèl nas compte 1' Arnau?

Qu' es aixó que 'us ix pèl nas? válgam Dèu val!"

"Son las cosas qu' he oloradas muller leal,

son las cosas qu' he oloradas viudeta igual!" 
"But I have not even touched you, Woman most true;

But I have not even touched you; Loyal are you."

"What is that flames from your forehead, Arnold, my knight?

What is that flames from your forehead?

Help, God of might!"

"All the evil things I thought once, Woman most true;

All the evil things I thought once;

Loyal are you."

"What is flashing from your eyeballs,

Arnold, my knight?

What is flashing from your eyeballs?

Help, God of might!"

"Those are my own evil passions,

Woman most true;

Those are my own evil passions;

Loyal are you."

"What is it flames from your nostrils,

Arnold, my knight?

What is it flames from your nostrils?

Help, God of might!"

"Evil things that I was smelling,

Woman most true;

Evil things that I was smelling;

Loyal are you." 


\section{Folk-Ballads of Southern Europe}

“'Qu' es lo que 'us ix per la boca compte 1' Arnau?

Qu' es lo que 'us ix per la boca? válgam Dèu val!"

"Son las malas parauladas muller leal,

son las malas parauladas viudeta igual!"

"Qué vos ix per las orellas compte 1'Arnau?

Qué vos ix per las orellas? válgam Dèu val!"

"Malas cosas qu' he escoltadas muller leal,

malas cosas qu' he escoltadas viudeta igual!"

“Qu' es aixó que'us ix pèls brassos compte 1' Arnau?

Qu' es aixó que 'us ix pèls brassos? válgam Dèu val!"

"Son las malas abrassadas muller leal, son las malas abrassadas viudeta igual!"

"Qué es lo que'us ix per las mans compte 1' Arnau?

Qué es lo que 'us ix per las mans? válgam Dèu val!" 


\section{Count Arnold}

"What is it from your mouth blazing,

Arnold, my knight?

What is it from your mouth blazing?

Help, God of might!"

"Evil words that I have spoken,

Woman most true;

Evil words that I have spoken;

Loyal are you."

"What is it from your ears burning,

Arnold, my knight?

What is it from your ears burning?

Help, God of might!"

"Evil things to which I listened,

Woman most true;

Evil things to which I listened;

Loyal are you."

"What is it from your arms flaming,

Arnold, my knight?

What is it from your arms flaming?

Help, God of might!"

"These are all my vile embraces,

Woman most true;

These are all my vile embraces;

Loyal are you."

"What is this on your hands burning,

Arnold, my knight?

What is this on your hands burning?

Help, God of might!" 


\section{Folk-Ballads of Southern Europe}

"Malas cosas qu' he tocadas muller leal,

malas cosas qu' he tocadas

viudeta igual!"

'Qu' es aixó que'us surt pèls peus

compte 1' Arnau?

Qu' es aixó que 'us surt pèls peus?

válgam Dèu val!"

"Son las malas trepitjadas

muller leal,

son las malas trepitjadas

viudeta igual!"

“Qu' es aquest soroll que sento

compte 1' Arnau?

Qu' es aquest soroll que sento?

válgam Dèu val!"

" Es lo cavall que m' espera muller leal,

es lo cavall que m' espera

viudeta igual!"

"Baixéuli '1 gra y la civada compte 1' Arnau,

baixéuli '1 gra y la civada válgam Dèu val!"

"No menja gra ni civada muller leal, sino ánimas condempnadas viudeta igual!" 


\section{Count Arnold}

"Evil things that I was touching,

Woman most true;

Evil things that I was touching;

Loyal are you."

"What is it from your feet flaming,

Arnold, my knight?

What is it from your feet flaming?

Help, God of might!"

"Evil steps that I have taken,

Woman most true;

Evil steps that I have taken;

Loyal are you."

"Why do I hear the sound of neighing, Arnold, my knight?

Why do I hear the sound of neighing?

Help, God of might!"

"' $\mathrm{T}$ is the horse for me a-waiting,

Woman most true;

' $\mathrm{T}$ is the horse for me a-waiting;

Loyal are you."

"Give him hay and grain for fodder,

Arnold, my knight;

Give him hay and grain for fodder;

Help, God of might!"

"He will eat no grain for fodder,

Woman most true;

Only spirits of the damned;

Loyal are you." 


\section{Folk-Ballads of Southern Europe}

"Ahont vos han donat posada compte 1'Arnau?

Ahont vos han donat posada? válgam Dèu val!"

"Al infern me l' han donada muller leal,

al infern me 1' han donada viudeta igual!"

"Perqué allí'us la han donada compte l'Arnau?

Perqué allí 'us la han donada válgam Dèu val!"

“Per pagar mal las soldadas muller leal, per pagar mal las soldadas viudeta igual!"

"Cada dia 'us faig la oferta compte 1' Arnau, cada dia 'us faig la oferta válgam Dèu val!"

"Vos dich no 'm feu pas la oferta, muller leal, que com mes me feu la oferta mes pena 'm dau.

* * * * * * * * *

"Tota sola feu la vetlla muller leal?

Tota sola feu la vetlla, viudeta igual?" 


\section{Count Arnold}

"Where now have they made your lodging, Arnold, my knight?

Where now have they made your dwelling?

Help, God of might!"

"Deep in Hell they made my dwelling,

Woman most true;

Deep in Hell they made my dwelling;

Loyal are you."

"Why should it in Hell be builded,

Arnold, my knight?

Why should it in Hell be builded?

Help, God of might!"

" $T$ is because I paid bad wages,

Woman most true;

' $T$ is because I paid bad wages;

Loyal are you."

"Every day I offer masses,

Arnold, my knight;

Every day I offer masses;

Help, God of might!"

"Offer for me no more masses,

Never again!

Masses offered for the damnèd

Bring them more pain."

* $\quad * \quad * \quad * \quad * \quad * \quad * \quad * \quad * \quad * \quad * \quad *$

"All alone do you keep vigil,

Woman most true?

All alone do you keep vigil?

Loyal are you." 


\section{Folk-Ballads of Southern Europe}

"No la faig jo tota sola, compte 1' Arnau,

no la faig jo tota sola válgam Dèu val!"

"Qui teniu per companyia muller leal?

Qui teniu per companyia viudeta igual?"

"Dèu y la Verge María compte 1' Arnau,

Dèu y la Verge María válgam Dèu val!"

"Ahont teniu las vostras fillas muller leal?

Ahont teniu las vostras fillas viudeta igual?"

"A la cambra son que brodan compte 1' Arnau,

a la cambra son que brodan seda y estam."

"Me las deixariau veure muller leal?

Me las deixariau veure viudeta igual?"

"Massa las espantariau compte l' Arnau, massa las espantariau válgam Dèu val!" 
"Not alone do I keep vigil, Arnold, my knight;

Not alone do I keep vigil;

Help, God of might!"

"Tell me, who are your companions,

Woman most true?

Tell me, who are your companions?

Loyal are you."

"I have God and Mary Virgin,

Arnold, my knight;

I have God and Mary Virgin;

Help, God of might!"

"Tell me where you keep your daughters,

Woman most true;

Tell me where you keep your daughters.

Loyal are you."

"They embroider in their chamber,

Arnold, my knight;

They embroider in their chamber

Silk and samite."

"Oh, I pray you, let me see them,

Woman most true!

Oh, I pray you let me see them!

Loyal are you."

"Far too much you would affright them, Arnold, my knight;

Far too much you would affright them;

Help, God of might!" 
“Deixáume 'n endú una filla muller leal, que ab mi passara las penas qu' estich passant."

"Aixis com las heu guanyadas válgam Dèu val!

tot sol com poguéu passáulas compte 1' Arnau."

"Solament la mes xiqueta muller leal,

solament la mes xiqueta viudeta igual!"

“Tant m' estimo la mes xica compte 1' Arnau, tant $m$ ' estimo la mes xica com la mes gran."

"Per qué no caséu las fillas muller leal?

Per qué no caséu las fillas viudeta igual?"

"Perqué no tinch dot per darlas compte 1' Arnau, perqué no tinch dot per darlas válgam Dèu val!"

“Al cap d' avall de la escala muller leal, al cap d' avall de la escala ne hi ha l' arjant." 


\section{Count Arnold}

"Let me see at least one daughter,

Woman most strong,

That my torture may pass from me;

I suffer long!"

"Even as you earned your tortures-

Help, God of might!

Even so they must pass from you, Arnold, my knight!"

"Only let me see the youngest,

Woman most true;

Only let me see the youngest;

Loyal are you.'

"Nay, I prize my youngest daughter,

Arnold, my knight,

Even as I prize the eldest;

Help, God of might!"

"Why do you not wed your daughters,

Woman most true?

Why do you not wed your daughters?

Loyal are you."

"' $T$ is because they have no dowry,

Arnold, my knight;

' $T$ is because they have no dowry;

Help, God of might!"

"At the foot of the great staircase,

Woman most true,

At the foot of the great staircase

Lies gold for you." 


\section{Folk-Ballads of Southern Europe}

"Son monedas malguanyadas

válgam Dèu val!

Son monedas malguanyadas

compte l' Arnau.'

"Ahont teniu los vostres fills

muller leal?

Ahont teniu los vostres fills

viudeta igual?"

"A la cambra son que jugan válgam Dèu val!

A la cambra son que jugan compte l' Arnau."

"Ahont teniu las vostras criadas muller leal?

Ahont teniu las vostras criadas viudeta igual?"

"A la cuyna son que rentan compte 1' Arnau,

a la cuyna son que rentan plata y estany."

"Me las deixariau veure muller leal?

$\mathrm{Me}$ las deixariau veure viudeta igual?"

"Massa las espantaríau compte 1' Arnau, massa las espantaríau válgam Dèu val!" 


\section{Count Arnold}

"All of it is gold ill-gotten,

Arnold, my knight;

All of it is gold ill-gotten;

Help, God of might!"

"Where have you your sons in keeping,

Woman most true?

Where have you your sons in keeping?

Loyal are you."

"They are in their chamber, gaming,

Arnold, my knight;

They are in their chamber, gaming;

Help, God of might!"

"Tell me where you keep your maidens,

Woman most true;

Tell me where you keep your maidens;

Loyal are you."

"They are in the kitchen, washing

Early and late;

They are in the kitchen, washing

Pewter and plate."

"Oh, I pray you let me see them,

Woman most true;

Oh, I pray you let me see them;

Loyal are you."

"Far too much you would affright them,

Arnold, my knight;

Far too much you would affright them;

Help, God of might!" 


\section{Folk-Ballads of Southern Europe}

"Ahont teniu los vostros mossos muller leal?

Ahont teniu los vostros mossos viudeta igual?"

"A la pallissa que dorman compte l' Arnau,

a la pallissa que dorman válgam Dèu val!"

"Paguéulos be la soldada muller leal, paguéulos be la soldada viudeta igual!"

“Aixis que 1' haurán guanyada compte l' Arnau, aixis que l' haurán guanyada, válgam Dèu val!"

"Quina hora es que '1 gall ja canta muller leal?

Quina hora es que '1 gall ja canta viudeta igual?"

"Las dotz' horas son tocadas compte 1' Arnau, las dotz' horas son tocadas válgam Dèu val!"

"Ara per la despedida muller leal,

ara per la despedida démnos las mans."

"Massa me las cremaríau compte 1' Arnau, massa me las cremaríau válgam Dèu val!"

BRIz y CANDI: Cansons de la Terra (Barcelona, 1866), vol. i., pp. 49-58. 
"Tell me where you keep your pages,

Woman most true;

Tell me where you keep your pages;

Loyal are you."

"They are in the stables sleeping,

Arnold, my knight;

They are in the stables sleeping;

Help, God of might!"

"Pay them well all of their wages,

Woman most true;

Pay them well all of their wages;

Loyal are you."

"I will pay them when they earn them,

Arnold, my knight;

I will pay them as they earn them;

Help, God of might!"

"The cock crows; what is the hour,

Woman most true?

The cock crows; what is the hour?

Loyal are you."

"Twelve o'clock but now has sounded,

Arnold, my knight;

Twelve o'clock but now has sounded;

Help, God of might!"

"It is the hour for our parting;

So must it be.

It is the hour for our parting;

Clasp hands with me!"

"How your hands are scorching my hands,

Arnold, my knight!

How your hands are scorching my hands!

Help, God of might!" 


\section{Folk-Ballads of Southern Europe}

\section{LE CHANT DU DAMNÉ}

Le mauvais riche vient à mourir,

Sa femme va prier sur sa tombe.

"Mon Dieu! rendez-moi mon mari,

C'est de bon cœur que je le dis!"

"Ma pauvre femme, reviens demain,

Reviens demains à la même heure,

$\mathrm{Tu}$ trouveras un feu ardent

Et ton mari sera dedans."

"Mon mari, si vous êtes là, Dites-le moi, je vous en prie." "Oh oui! ma femme là je suis, Pour toi, pour moi me faut souffrir.

"Ma femme t'en souviens tu pas De la mesure qu'il y a dans la grange?

$\mathrm{Si}$ tu ne la fais pas régler

Dans les enfers tu viendras brâler.

“Ma femme t'en souviens tu pas

Des pauvres qui venaient à la porte?

Au lieu de leur avoir donné,

Les avons toujours rebutés.

"Ma femme t'en souviens tu pas

Des livres qu'il y a dans ma chambre?

$\mathrm{Si}$ tu les as pas plus lus que moi

Dans les enfers tu brûleras.

“Ma femme t'en souviens tu pas

Du premier jour de nôtre noces?

Le premier jour des ribotés

Nous l'avons pas encore payé. 


\section{The Song of the Lost Soul}

\section{THE SONG OF THE LOST SOUL \\ (French)}

The wicked rich man he is dead,

His wife goes to his tomb to pray:

"O my God, give my husband back,

With all my heart I beg to-day."

"O my poor woman, come again, To-morrow at this hour return; You will find then a glowing fire, And in it will your husband burn."

"O my poor husband, if you 're there, I pray you speak to me again."

"Oh yes, my wife, yes, I am here!

For you and me I bear this pain.

"Do you remember, O my wife, That measure in the grange, now tell? You must have it made to measure true, Or you will surely burn in Hell.

"The beggars, O my wife, that came To our house door, do you recall?

Instead of giving alms to them, How you and I refused them all?

"Do you remember, O my wife, The books that in my chamber lie? You will surely come to burn in Hell, Unless you read them more than I.

" Do you remember, O my wife, The feasting on our wedding-day? For all those days of festival, O wife, there is the bill to pay. 


\section{Folk-Ballads of Southern Europe}

"Ma femme t'en souviens tu pas

Des bagues d'or que je t'ai données?

Les bagues d'or que je t'ai donnés

Je les dois encore aux orfévriers.

"Ma femme t'en souviens tu pas

Des beaux souliers que je t'ai données?

Les beaux souliers que je t'ai donnés

Je les dois encore au cordonnier.

"Ma femme t'en souviens tu pas

Des beaux habits que je t'ai données?

Les beaux habits que je t'ai donnés

Les marchands n'en sont pas payés.

"Adieu, ma pauvre femme, adieu, Je m'en vais dans un pays étrange, Adieu pour toute l'éternité,

Adieu' pour toujours je suis damné."

SMith, Victor: Chants de Pauvres, Romania (Paris, 1873), vol. ii., p. 456 .

\section{AR VINOREZIK A DRAON AL LANN}

Ar vinorezik, 'draon al lann,

'Deuz glac'har da varo hi mam;

Medi noz-dez o estlami,

Hi c'hovezour 'n deuz poan gant-hi.

*

P'oa war bez hi mamm 'n orezon,

'Klewaz ann anter-noz o soon;

Klewaz ann anter-noz o soon;

Erru koulz ar prosession. 


\section{The Girl and Her Mother's Soul 247}

"Have you forgotten, $\mathrm{O}$ my wife, The jewels of gold do you forget? For the jewels of gold I gave to you,

I have not paid the goldsmith yet.

"Have you forgotten, $\mathrm{O}$ my wife, Your pretty shoes do you forget? For the pretty shoes I gave to you, The shoemaker is not paid yet.

"Do you remember, O my wife, Your pretty clothes, do you forget? For the pretty clothes I gave to you,

I have not paid the merchants yet.

"Farewell, O my poor wife, farewell!

I go to a strange land, farewell!

Farewell for all eternity,

Farewell, for I am damned in Hell."

THE YOUNG GIRL AND HER MOTHER'S SOUL (Breton)

A maiden of the countryside

Is mourning since her mother died;

She grieves all night and all the day;

The good priest knows not what to say.

As she is at the tomb praying,

She hears the bells of midnight ring;

She hears the bells of midnight ring,

The hour when spirits are walking. 


\section{Folk-Ballads of Southern Europe}

Erru ez int en ter vandenn, Re du ha re c'hriz ha re wenn.

' $\mathrm{N}$ touez ar re du a well hi mamm, O Doue, pebeuz da estlamm!

Deiz warlerc'h da noz ' $z$ ia 'darre War bez hi mamm d'bedi Doue.

P'oa war ar bez en orezon, 'Klewaz ann anter-noz o soon;

'Klewaz ann anter-noz o soon, Erru oa koulz 'r prosession.

Erru int e-tre ter vandenn, Re du ha re c'hriz ha re wenn.

'N touez ar re-c'hriz a well hi mamm, $\mathrm{Na}$ doa ket kement a estlamm.

Deiz warlerc'h 'noz ez ia 'darre War bez hi mamm d'bedi Doue.

$\mathrm{Pa}$ oa war ar bez, 'n orezon, 'Klewaz 'ann anter-noz o soon;

Klewaz ann anter-noz o soon, Erru koulz ar prosession.

Erru int etre ter vandenn, Re du ha re c'hriz ha re wenn.

Touez ar re-w^nn a well hi mamm, Neuze na doa ken a estlamm. 


\section{The Girl and Her Mother's Soul 249}

They walk in groups of three that night, The black, the gray, and then the white. Among the black the mother goes. O God! what fear the daughter knows!

The next night she is come again To pray God for the soul in pain: As she is at the tomb praying, She hears the bells of midnight ring; She hears the bells of midnight ring, The hour when spirits are walking. And in three groups they walk that night, The black, the gray, and then the white. Among the gray the mother goes, And less of fear the daughter knows.

The next night she is come again To pray God for the soul in pain; As she kneels on the grave praying, She hears the bells of midnight ring; She hears the bells of midnight ring, The hour when spirits are walking. And in three groups they walk that night, The black, the gray, and then the white. Among the white the mother goes, And no more fear the daughter knows. 


\section{Folk-Ballads of Southern Europe}

' $N$ hi davanjer ez eo kroget, En pewar zamm deuz-han laket,

Hi mamm evelhenn deuz laret:

- Penamet oud en graz Doue,

'M boa da diframmet a beziou, 'Vel ma rez d'as davanjerou!

Ur bugel a t'euz bet dalc'het, Em hano a t'euz-han laket,

Hag hennes hen euz ma zalwet!-

Luzed, F. M.: Chants Populaires de la Basse-Bretagne (Lorient, I868), vol. i., pp. 64-67.

\section{LA MADRE RISUSCITATA}

Povra mare ch'a l'è morta, due maznà ch'a j' à lassà.

E'l pare ch'a s'armarida, n'áutra spuza ch' a s'è pià.

La marastra tan crüdela povri anfan a i fa stantè.

Ël pi cit l'è sensa báila, s'a n'in fa che tan piurè. Ël pi grand a'l lassa s' l'āra sensa béive nè mangè, Sensa capelin an testa e sensa le scarpe ai pè. 


\section{The Dead Mother Restored}

She took the apron that she wore And tore it into pieces four.

Then to the girl the mother cried:

"Had God's grace not been on thy side,

Thou had'st been into pieces torn

Even like the apron thou hast worn.

Thou hast named for me thy newly-born

Godchild, in church, and that was well;

The child has saved my soul from Hell."

\section{THE DEAD MOTHER RESTORED (Piedmontese)}

The poor mother she must die Leaving two little boys to cry.

The father quickly marries another, Giving his children a stepmother.

The new wife does a eruel thing; She leaves the children perishing.

The baby on his bed is lying,

Without a nurse, and always crying .

The elder son is left in the strcet, With nothing to drink and nothing to eat;

Without a cap for his little head, Or shoes for his feet, now his mother's dead. 


\section{Folk-Ballads of Southern Europe}

Tanto fort cum' a criavo,

la mare s'a j'à scutà;

Tanto fort cum' a piuravo, de la fossa a l'è arsüssità.

Al pi grand a i dà la süpa,

èl pi cit lo fa püpè;

Ël pi grand a lo pentnava, èl pi cit a'1 l'à bazè.

Nigra, C.: Canti Popolari del Piemonte (Torino, 1888), No. 39, pp. 212-213.

\section{MALEDIZIONE DELLA MADRE}

La vedovela l'à na fieta,

Bela biundina da maridè.

S'a j'è passà-je lo re di Fransa,

Për sua spuzëta la va ciamè.

So fradelino da 'n sü la porta:

"O mama mia, lassei-la andè."

La sua mama de la finestra:

"La mia fieta la vöi pa dè."

An bel fazenda ste paroline,

La bela an sela a l'è muntè.

"O va-t-ne, va-t-ne, la mia fieta,

Che drint al mar che t'pösse niè." 


\section{The Mother's Curse}

So loud and long the little boy cries, The mother hears him where she lies.

So loud and long the little boy weeps, Out of her grave the mother creeps.

His supper she feeds to her elder son, And sweetly kisses the little one.

She combs the boy's tangled locks, The baby in her arms she rocks.

\section{THE MOTHER'S CURSE}

(Piedmontese)

Soon the widowed mother must marry her young daughter;

But on a day a noble king came riding down by chance;

He saw her two white hands, he saw her golden tresses, And wooed the little maiden, to make her Queen of France.

The girl's little brother he cried from the doorway:

"Oh, let her go, my mother, she will be bravely wed." But the girl's mother she looked from the window:

"I will never give my daughter to such as you," she said.

Now the fair little maiden, while her mother 's speaking,

Has mounted to the saddle as nimbly as may be:

"Oh, go your own way, oh, go your way, my daughter, And may you be drowned in the depths of the sea!" 


\section{Folk-Ballads of Southern Europe}

Quand a l'è stáita an riva al mare,

Povra fieta s'büta a tremè.

"O ten-te, ten-te, la mia spuzëta,

Ten-te a la sela dël me caval."

"Mi na podria mai pi tenì-me,

Che la mia mare m'a sentensià;

E la sentensa de pare e mare

A l'à da esse la verità.

"Mi povra fia, povra fieta,

Che drint al mar e l'ái da niè.

Le mie trësse così biundine

An fund a l'aqua l'àn da marsè.

"Lo mio sangue l'è cozì dolce;

$\mathrm{Da}$ le baléine sarà sücià;

Le mie manine sun cozì bianche;

Dai pess dël mar a saran mangià."

"O marinari de la marina,

La mia spuzëta vorì pëschè?

Se mia spuzëta la pëschi morta,

Duzento scüdi vi voi ben dè;

"Se mia spuzëta la pëschi viva,

Lo che vorì me porì ciamè."

Sa l'àn pëscà-la tre di, tre notti;

Bela biundina l'àn pi truvì.

Nigra, C.: Canti Popolari del Piemonte (Torino, 1888), No. $23 \mathrm{~A}$, pp. 15I-I 55 .

\section{LA DANNADO}

- "Digo, digo, lou haure, (bis)

Per quant ma mulo bos herra? (bis)

-Acò es cinq sos, moun prince,

Cinq sos e un dinè. 
When they came to the seashore the little maiden trembled;

"Now hold fast by the saddle, my bride, till we are through."

"Oh, I cannot hold, I cannot; my mother she has cursed me;

And the curse of a mother or a father must come true.

"I, a poor little girl, must be drowned in the water!

Each little white hand will be gnawed until it bleeds; My blood that is so sweet will be sucked by the fishes; My hair that is so yellow will be tangled in the weeds."

"O sailors of the sea, will you fish for my sweetheart? You shall have two hundred scudi, if you find her drowned;

If you find her living, you may have your will for asking."

They have fished for three days, but the maid they have not found.

\section{THE ACCURSĖD}

(Gascon)

"Blacksmith, blacksmith, say now, say,

For what will you shoe my mule to-day?"

"My prince, for five sous, for five sous

And one centime, I '1l set her shoes." 


\section{Folk-Ballads of Southern Europe}

-Digo, digo, lou haure,

Se ma mulo tendras.

- Jou que n'èi tengut d'autos.

Aquesto que tendrèi.

-Au prumè her que boutes,

Pai te ba apera."

Au prumè clau que bouto,

Pai que l'a aperat.

-Qui es-tu, insoulento,

Que pai m'as aperat?

-La bosto hillo Jano,

Jè m'auètz enterrat.

-Digo, ma hillo Jano,

Qui t'a hèito danna?

-Lou curé de Lalando,

Lou loung dou bernissa.

Quant jou èri pastoureto,

M'i benguèuo trouba.

Ma so, qu'es a la caso,

L'i dèchetz pas ana.

Autroment, lou men pèro,

Bous que boun batz danna.

Las hardos qu'èi a caso,

L'ac dèchetz pas pourta.

Prenguètz, prenguètz, las toutos,

Enta las hè burla.

Toutos, toutos las cenes, (bis)

Au bent las cau jita. (bis)

BladE, J.-F.: Poésies Populaires de la Gascogne (Paris, 1882), vol. ii., pp. 142-I46. 


\section{The Accursèd}

"Blacksmith, blacksmith, tell, now tell, Do you think you can hold her well?"

"I have held the like of her;

I 'll hold her so she cannot stir."

"The first shoe you set in place, She 'll call you 'Father' to your face."

The first shoe he sets in place,

She calls him "Father" to his face.

"What art thou, insolent fool?

Am I called 'Father' by a mule?"

"I am Jeanne, thy daughter dead, That yesterday was buried."

"O my daughter, tell to me Who is it has cursèd thee?"

"Down along the river's strand Came the curé of Lalande;

"When I kept the sheep for thee, He would always seck for me.

"My sister's in the house, and oh, Never, never, let her go!

"If you do, my father, know You will be accursed also.

"My clothing in the house there, bring,

Never let her wear a thing;

"Everything that was mine take And burn with fire, for her sake.

"All the ashes that you find You must scatter to the wind." 


\section{$25^{8}$ Folk-Ballads of Southern Europe}

\section{H BOH TOY MNHMATOE}

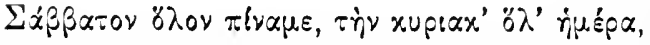

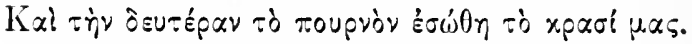

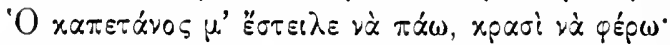

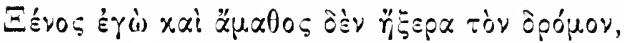

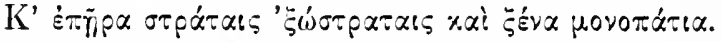

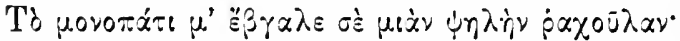

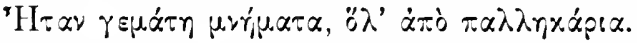

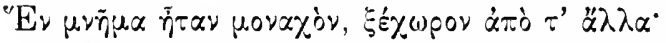

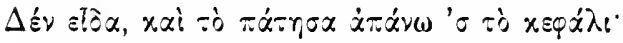

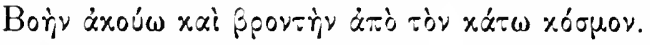

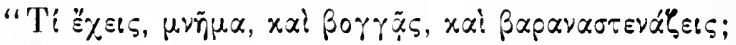

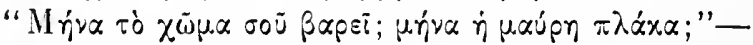

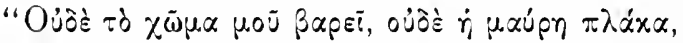

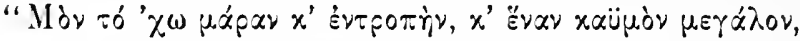

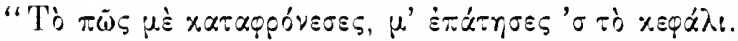

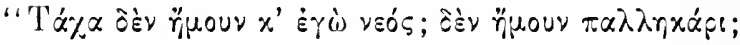

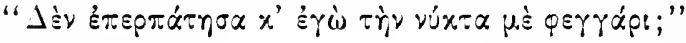

Fauriel, C. C.: Chants Populaires de la Grèce (Paris, 1825), vol. ii., pp. $400-401$. 


\section{The Voice from Underground 259}

\section{THE VOICE FROM UNDERGROUND (Modern Greek)}

All Saturday we were drinking, and Sunday the day through;

On Monday morning our wine was gone and what were we to do?

The captain sent me out to fetch more wine that day, But, a stranger, with no guide, I could not find the way;

And so I took wrong roads, and secret paths, until One little lonely pathway led me out on a high hill.

The place was full of tombs, all tombs of soldiers brave,

And apart from all the rest there was a single grave;

I trod across its head for I did not see the mound;

I heard a rumbling voice from the world below the ground:

"What is the matter, tomb, that you sigh so loud and groan?

Perhaps earth weighs you down, or is it this black stone?"

" ' $\mathrm{T}$ is not the earth that weighs, nor is it the black stone,

But I suffer and am shamed, and with great pain I groan,

Because you have despised me, treading across my grave.

Perhaps I was not young, I too! Was I not brave? Have I not walked, I too, by night under the moon?" 


\section{MIORIT3A}

Pe-un pičor de plaiŭ,

Pe-o gură de raiŭ,

Eată vinŭ în cale,

Se coborŭ la vale

Treĭ turme de mier̆

$\mathrm{Cu}$ treĭ ciobăneŭ.

Unu-ĭ Moldovan

Unu-ĭ Ungurean

Şi unu-1̌ Vrancean.

Ear cel Ungurean

Şi cu cel Vrancean.

Mări, se vorbiră,

Eŭ se sfătuiră

Pe l'apus de sóre

Ca se mi'l omóre

Pe cel Moldovan

Că-ĭ mal̆ ortoman,

S'are or mă multe

Mîndre şi cornute,

Si cal învățaţŭ

Si cânı̆ ma1̆ bărbaţ̣̌!

Dar cea Mioriț̆a

Cu lână plăviță

De treĭ đ̧ile 'ncoace

Gura nu-1̌ maǐ tace,

Érba nu-1̆ mă place,

“-Mioriț̆ lae,

Lae, bucalae,

De treĭ đ̧ile 'ncoace

Gura nu'ţ̌ mar̆ tace!

Orí érba nu'ț̌ place,

Ory eștu bolnăvióră 


\section{THE LITTLE LAMB \\ (Roumanian)}

Where a mountain valley lies Beautiful as Paradise,

To a pasture green and deep,

Came three shepherds with their sheep.

One was out of Hungary,

Moldave was the second herd,

Vrancian mountaineer the third.

Now the herd of Hungary, And the Vrancian, jealously, Vow to kill the young Moldave When the sun a-setting lies; $\mathrm{He}$ is hateful in their eyes, For he is so rich and brave; Many well-horned sheep he leads, Trusty dogs and goodly steeds;

But a white lamb, curly-fleeced, Of the Moldave's flock the least, Through three days no grass will eat, Only sadly bleat and bleat.

"Whitest little lamb of mine, Tell to me that pain of thine; For three days, so mournfully Crying, thou hast followed me; Here the grass is green and sweet, Art thou sick and wilt not eat, 
Drăguţă Mióră?

-Drăguţule bace!

Dăţŭ oile 'ncoace

La negru Zevoĭ,

Că-Ý érbă de nơ̆

Şi umbră de vol.

Stăpâne, stăpâne,

İţ̆ chăamă ş'un câne

Cel mẳ bărbătesc

Şi cel maĭ frățesc

Că l'apus de sóre

Vréŭ se mi te-omóre

Bacŭul Ungurean

Si cu cel Vrancean!

-Oiţă Bîrsană,

De escĭ năsdravană

Şi de-a fi se mor

In câmp de mohor,

Se spuĭ luĭ Vrancean

Şi luĭ Ungurean

Ca se me îngrópe

Aice pe-aprópe

In strunga de ŏ,

Se fiŭ tot cu voř;

In dosul stînir

Se'mì aud cânir.

Aste se le spui,

Ear la cap se'mí pư

Flueraş de fag,

Mult ḑice cu drag!

Flueraş de os,

Mult dice duos!

Flueraş de soc,

Mult_dice cu foc! 
Dearest little lamb of mine?"

"Shepherd, O my shepherd dear!

Lead the sheep afar from here;

Yonder in the great, dark wood,

For us there is pasture good;

Shade for us and thee is there;

Master, listen to my prayer.

Of thy dogs, the bravest, best,

Take with thee, and trustiest;

For the man of Hungary, And the Vrancian, cruelly At nightfall will murder thee."

"Curly lambkin, if indeed

Thou canst in the future read;

If Fate wills I die to-day,

In this meadow, thou must say

Bold to him of Hungary,

Boldly to the mountaineer,

That they lay my body here,

Close beside my herd-hut small, So I may stay near you all;

Stay among my sheep and still

Lie and listen underground

To my dogs upon the hill.

See thou, when my grave is made, Over me my three flutes laid;

One all wrought of beechen wood

Sings how love is true and good;

One that 's carved of ivory

Tells the heart's pain, tenderly;

One of elder-tree that loud

Sounds of joy and courage proud. 
Vîntul când a bate

Prin ele-a resbate

S'oile s'or strînge

Pe mine m'or plânge

Cu lacrimĭ de sânge!

Ear tu de omor

Se nu le spuí lor.

Se le spuĭ curat

Că m'am însurat

Cŭ-o mîndră Craésă,

A lumeĭ mirésă ;

Că la nunta mea

Aŭ căḑut o stea;

Sórele şi luna

Mù-aŭ ţinut cununa.

Braḑu și paltinaş̆

$\breve{I}$-am avut nuntaşu,

Preoțĭ, munțiǐ marŭ,

Paseř̆, lautarı̆,

Păserele miŭ,

Şi stele făcliı̀!

Ear dacă-ı̆ zări

Dacă-1̌ întâlni

Mâưcuță batrînă

$\mathrm{Cu}$ brîul de lână,

Din ochĭ lăcrimând.

Pe câmpì alergând,

De toțu întrebând

Şi la toţ̧ đ̧icând:

Cine-aŭ cunoscut

Cine 'mĭ aŭ vědut

Mîndru chobănel

Tras printr'un inel? 
When the wind comes softly creeping, And awakes my flutes from sleeping, All my sheep will gather round, Shedding tears upon the ground. Lambkin, no word shalt thou tell In what wise my death befell;

Say I wed a royal bride, Wooed of all the world beside; Say that when our faith was given, A bright star fell out of Heaven; Sun and moon stood holding there A marriage-wreath above my hair; Mountains tall were priests to me;

Guests were pine and alder-tree; Torches were the flaming stars, Thousand birds my lute-players.

"If thou should'st my mother meet, With her woolen girdle brown, And her poor eyes weeping down Bitter tears; on trembling feet, Through the meadows hastening, All the people questioning:

'Who has seen my shepherd-lad?

Is no other like to him, My young shepherd, straight and slim, Fit to leap through ring and ring; 
266 Folk-Ballads of Southern Europe

Feçişóra luĭ

Spuma lapteluí;

Musteţ̌óra luĭ

Spicul grâulư̆;

Perişorul luĭ

Péna corbulư̌;

Ochişoriư luĭ

Mura câmpulự! . . .

Tu, Mióra mea,

Se te 'ndurĭ de ea

Si-1̌ spune curat

Că m'am însurat

Cŭ-o fată de Craiŭ

Pe-o gură de raiŭ.

Ear la cea măı̆cuţă

Se nu spư̆, drăguţă,

Că la nunta mea

A căḑut o stea,

C'am avut nuntaşy

Braçı̆ şi paltinaşŭ,

Preoţ̌, munţiì marŭ,

Paserĭ, lăutarĭ,

Păserele miı̆

Şi stele făcliıı! . . .

Alecsandri, Vasile: Poesir Populare ale Romanilor (BucurescY, I 866), pp. I-4. 


\section{The Little Lamb}

Like the milk-foam his white skin, Black his hair as raven's wing, Like ripe corn his bearded chin, Brown his eyes as mulberries, Brown and dark those eyes of his.'

"To her, pitying, thou shalt say

A fair queen I wed to-day,

In a far-off land that lies

Beautiful as Paradise.

To my mother never tell

How from Heaven a bright star fell;

How the peaks were priests to me,

My guests pine and alder-tree;

How my torches were the stars, And the birds my lute-players." 


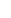




\section{NOTES}





\section{THE SUN AND THE MOON}

This ballad was found by Miss Jewett not only in the Roumanian but also in the French verse of Vasile Alecsandri, a romantic poet of Roumania in the mid-nineteenth century and a collector of the national folk-songs. In this pursuit, which occupied him for several years, he traversed on foot the mountains and plains of Roumania, listening to the peasants as they sang, to slow and plaintive airs, the ballads of their native land. A small volume, containing his translations into French verse or prose of twenty-four of these ballads, was published at Paris in 1855 , with an introduction by his friend, M. A. Ubicini. In 1859 Johann Karl Schuller issued Romänische Volkslieder, where a number of Roumanian ballads, including The Sun and the Moon and The Little Lamb, are rendered into German verse. In this same year, Grenville Murray published in London Songs and Legends of Roumania, where are retold, in simple prose, these two stories, together with those of Bujor and Shalga and others. The Sun and the Moon and The Little Lamb reappeared in German verse in A. Franken's Rümanische Volkslieder und Balladen in I 889.

In his notes on Le Soleil et la Lune (Soavele si Luna) Alecsandri states that the beautiful Helen with golden hair is the heroine of many a folk-tale. He explains, too, that at Roumanian weddings the bride, in lieu of wearing a veil, is crowned with an ornament of golden floss that falls about her in long tresses. In Helène Vacaresco's Songs of the Valiant Voivode there is given, in the lay of The Young Prince, Who, Born of a Rose-Tree, Became a RoseTree Himself, a different legend of sun and moon.

"The moon walks on the leaves and walks so lightly

That not one leaf is stirred.

The stars are dead because the moon has killed them,

And yet she smiles, the murderous moon. 
You see I know all the white moon's dark secrets,

It 's she herself that kills the sun,

And on the sky her knife is bloody, but the sun rises from his tomb,

And every night

She has to kill again."

"But the sun rises every morning from his red tomb.

Now to-day I have heard a strange thing, my fair husband.

The moon still loves the sun,

And they are wedded;

They have a marriage ring.

It is made of the gold of the sun

And the silver of the moon,

Exactly like our own."

\section{THE NOBLE SIBILLA}

This ballad was taken down from the singing of a peasant woman in the neighborhood of Marsala and first printed (in Nuove Effemeridi Siciliane, Nuova Serie, i., 528) in 1874. Four years later it was reprinted and discussed by Felix Liebrecht (in Zeitschrift für deutsche Philologie, ix., 53-64), who contended that the ballad, instead of being founded, as had been assumed, on the actual adventures of a lady stolen by Tunisian corsairs about 1500, bears all the marks of a fairy-tale. Its variants, which Liebrecht had already traced in Italy, Belgium, Germany, England, Russia, have since been found to be remarkably numerous. See Child, No. 95; The Maid Freed from the Gallows.

\section{THE SAILOR}

A close analogue to this Catalonian ballad is the Piedmontese Il Marinaro (Nigra, No. 44), but the hint of magic music connects it with the English Glasgerion (Child, No. 67). The following ballad, The Corsair, also gives strange power to the sailor's song.

\section{THE CORSAIR}

Nigra (under No. 14) classifies the many ballads upon this theme, and Child, in his discussion of Lady Isabel and the ElfKnight (No. 4), to which this ballad, like the preceding, is allied by 
the magic music and, unlike the preceding, by the woman's resort to craft, carefully distinguishes (vol. i., p. 45) The Corsair and its parallels from those ballads in which the maiden slays, not herself, but her abductor. Victor Smith notes (in Romania, vol. vii., p. 67) that the folk-songs of ship-stolen maidens are naturally found in their most complete form in maritime provinces.

\section{THE MOOR SARACEN}

This ballad is discussed by Nigra (under No. 40) at the length of thirty-seven pages, the names of the characters and every incident of the action, with the folk-lore variants, being passed in review. The recognition by means of the ring links it lightly to Hind Horn (Child, No. 17), but the great diffusion of the ballad is, of course, in Southern Europe, especially in Provence, Piedmont, and, above all, in the Spanish Peninsula, where Castilian, Portuguese, and Catalan versions abound. See Cribete.

\section{CRIBETE}

This tragic Gascon version of the popular ballad preceding (see note on The Moor Saracen) excels in beauty. Here the scene is localized by reference to the river Oviedo in the mountain region of Northwestern Spain. Folk-songs of stolen brides are common and of wide distribution. "The ballad of the stolen bride," notes Miss Jewett, "is the most primitive in situation, though often the example is late." She notes again that stealing a bride is "as natural to simple society as stealing a horse." The latter tendency has left its trace on English balladry in The Lochmaben Harper (Child, No. 192), the former in Katharine Jaffray (Child, No. 22I), on which Scott's Lochinvar is founded, and in the later Lord William or Lord Lundy (Child, No. 254). Miss Jewett summarizes as follows a Roumanian parallel (Alecsandri, No. II) entitled Novak and the Daughter of the Kadi: "When the prince Jovitza has stolen away the lady, her father pursues in wrath to the very palace of the aged Novak, uncle and protector of Jovitza. As the angry father lifts his sword to strike the culprits, Novak appears. The old man slowly raised his long lashes to look upon his guest and said to him: 'Stay thy hand, Kadi my brother, and remember these words: Young folk make quarrels, and the old make peace." 


\section{COUNT SOL}

Duran found this ballad well known among the peasants of Andalusia, especially in the neighbourhood of Ronda. Many analogues, Northern and Southern, are enumerated by Child under Young Beichan (No. 53). See also Nigra's discussion under Moran d'Inghilterra (No. 42). Of the Piedmontese version Miss Jewett says: "This Italian ballad is spirited but trivial, lacking the naive pathos of Young Beichan and the grace of $E l$ Conde Sol." Miss Jewett notes resemblances borne by the ballads to Beves and other English romances (see Three Middle English Romances retold by Laura A. Hibbard, Nutt, London, I9II,a book dedicated Alla mia Maestra Sophie Jervett) and finds an interesting Modern Greek parallel in Tommaseo's Canti Greci, iii., p. II2.

\section{THE PILGRIM}

This tragic variant of $E l$ Conde Sol is an old and favorite ballad of Portugal. Almeida-Garrett states that he found fragments of it the country through.

\section{HERO AND LEANDER}

The story of these famous lovers, though of ten so altered that Musæus would hardly recognize his own, appears in many Continental ballads, not only of the Latin countries, but of Germany, Scandinavia, and the Netherlands. This Piedmontese version was recited in Turin, Nigra states (under No. 7), by an old woman who could barely read and write and certainly knew nothing of the classic original of her tale.

\section{THE TEST}

This is one of the most popular of folk-lore subjects. Nigra enumerates (under No. 54) parallels in various Italian dialects, in French, Spanish, Portuguese, German, and Modern Greek. Our English analogue is The Bailiff's Daughter of Islington (Child, No. 105).

\section{PIERRE OF GRENOBLE}

In certain French and Italian variants of this ballad the sweetheart, Nannette, is already buried, but rises from the grave to bid her lover return to his duty as a soldier. 


\section{THE DEAD BRIDE}

All folk-song delights in lovers who die for love, as the popularity of Bonny Barbara Allan (Child, No. 84) readily witnesses. The Dead Bride, whose parallels abound in the dialects of Southern Europe, connects with English balladry, more or less directly, through Lord Thomas and Fair Annet (Child, No. 73), Fair Margaret and Sweet William (Child, No. 74), and Lord Loiel (Child, No. 75).

\section{CATALINÒTA}

This ballad is a variant of the preceding. Nigra (No. 17) gives four full Piedmontese versions of this story, of which Miss Jewett translated the first (The Dead Bride) and the fourth (Catalinota).

\section{BRIDAL DANCE AND FUNERAL}

Nigra (under No. 20) conneets this ballad, whose Freneh and Italian analogues he notes, with Lord Thomas and Fair Annet (Child, No. 73), but the analogy is closer with Fair Janet (Child, No. 64).

\section{FLOWERS FROM THE GRAVE}

On these "vivacious growths" see Nigra (No. 19, Fior di Tomba) and Child (No. 7, Earl Brand; No. 64, Fair Janet; No. 73, Lord Thomas and Fair Annet; No. 74, Fair Margaret and Sweet William; No. 75, Lord Lovel; No. 76, The Lass of Roch Royal; No. 85, Lady Alice; No. 87, Prince Robert, and No. 222-version in Appendix, vol. v., p. 26I-Bonny Baby Livingston).

Miss Jewett notes: "Of all the stock material of the romantic ballads, perhaps the fancy that has the widest circulation is that of the flowers, vines or trees that spring from lovers' graves. The rose and the brier that spring from the graves of dead lovers in the British ballads have analogies all over the Continent. Prof. Child and Count Nigra devote many pages to collecting and comparing the different forms in which these symbols of faithfulness or of innocence appear. Prof. Child's illustrations are taken from nearly twenty different languages. In the British ballad only the brier, birk, and rose are found. In other Germanic ballads there are roses, lindens, pinks, and rue; but most commonly, especially in the German, it is the lily that blossoms on the 
grave of knight or maiden. It will be noticed that in the Southern ballads roses and lilies give place, for the most part, to firs, cypresses, olives, pines, and orange or lemon trces. Loveliest of all are the reeds that, growing from a maiden's grave, as in The Pilgrim, sigh in the night, or are bowed by the wind to kiss the cypress, as in this Modern Greek folk-song (from Tommaseo: Canti Greci in Canti Popolari, vol. iii., p. 64):

'And the girl became a reed, And the youth a little cypress tree.

The wind bent the reed so that it kissed the cypress:

If they might not kiss living,

Dead they kiss each other.'

"It is of course useless to conjecture whether this much loved fancy has strayed into poptlar song from the great medieval romances, or whether the romance writers made use of an already familiar symbol; or whether romance and ballad alike have inherited a bit of beauty from Greek myth. In any case, this fancy has attached itself to the two greatest of medieval love stories. The rose and vine are immortal with the love of Tristan and Isolde; and the yew-tree with that of Deirdre and Naisi."

In illustration of the above, Miss Jewett would cite the myths of Hyacinthus and Ajax, together with the following passages:

(From Gottfried von Strassburg's Tristan und Iseult, translated by Jessie Weston, vol. ii., pp. I54-5.) “'Then he [Mark] bade them embalm the bodies, and he bare them back with him to Tintagel, and laid them in marble tombs on either side of the chapel wherein the kings of his line lay buried. And by the tomb of Tristan he bade them plant a rose-tree, and by that of Iseult a vine, and the two reached towards each other across the chapel, and wove branches and root so closely together that no man hereafter might separate them."

(From The Cuchullin Saga in Irish Literature, retold by Eleanor Hull, p. 53, note at end of The Sons of Usnach.) " 'It is said that King Conchobar was so incensed that Naisi and Deirdre should even in death dwell in the mansion of the grave together, that he ordered them to be laid far apart in the burial-ground. Every morning for some days, however, the graves would be found open, and Naisi and Deirdre found together in one of them. Then Conchobar ordered that stakes of yew should be driven severally through their bodies, in order to keep them asunder. But two 
yew-trees sprang from these two stakes, which grew to such a height that they embraced each other over the cathedral of Armagh.'"

Miss Jewett's unrevised translation of the Roumanian ballad of The Veil and the Ring (Alecsandri, No. v.) may appropriately be added here:

"There was once,- - there was a prince,

Young, a splendid lad,

Like a fir-tree of the forest

Upon the peak of the mountains.

He has taken to wife a maiden of the village,

A Roumanian maiden beloved of all the neighborhood,

Like a flower of the field that shines in the sun.

Now there has come to him the order to return to the camp and he sadly says to her:

'Sweetheart mine, soul of mine! Take thou this my ring, put it upon thy finger. When the ring tarnishes, Thou wilt know, beloved, that I am dead.'

She says likewise to him:

'Take thou my veil of silk with fringes of gold.

When the gold fades, thou wilt know, sweetheart, that I am dead.'

He throws himself into the saddle and goes on a long journey. He comes to a place where he lights a great fire in the midst of the forest by the fountain of the crows. He puts his hand into his breast and takes out the veil. He looks upon it and his heart is broken.

'My dear comrades, my good fellows, valiant ones, Stay ye here and eat and rest in the shade.

At home I have left, forgotten, my sword, thrown upon the green table.'

He goes on his way and meets a brave fellow on a little horse.

'Good fellow, brave youth, What was the news when you left?'

'If thou wilt hear, seigneur, know that the news may be good for some one else; it is anything but good for thee. 
'Thy father has raided the country, he has thrown thy bride into a river broad and deep.'

The prince bursts into tears and cries out:

'Here, neighbor, take my steed; conduct it to my father. If he asks what has become of me, tell him I have thrown myself from the bank of the river to find the woman I love.'

His father has raised a company; they have dragged the river, dragged and searched it, and found the youths locked in each other's arms, lying bright on the sandy bed of the stream, with their yellow tresses and their faces' rosy glow.

They take them to the church, they array them in beautiful shrouds. They bury him near the sacred altar toward the East; her near the door to the West.

From his grave, brother, sprang up a beautiful fir-tree and bent over the church. From hers shot a vine, whose soft tendrils climbed along the wall to entwine the fir.

O God! Lord God! strike with thine avenging lightning, Strike those who would break the cords that bind together two young hearts."

\section{THE TWO GRAVES}

Of this Piedmontese ballad Nigra gives (No. 18) eight versions, with interesting variations in the names of the towns. $\mathrm{He}$ appends a page of discussion along the lines of the preceding note. See Flowers from the Grave.

\section{COUNT ARNAUD}

This story is one of the most widely diffused of Continental folk-tales. The coming home of the death-stricken son to his mother suggests analogy with Lord Randal and Edward Edward, but our true English analogue is Clerk Colvil (Child, No. 42), although this preserves the earlier part of the story, missing in the Gascon ballad and in its beautiful Venetian variant following, and loses the dialogue between the young wife and her husband's mother. With these two Miss Jewett apparently had in mind to translate a third, Le Seigneur Comte, given by Luzel 
(Contes Populaires de la Basse-Bretagne, vol. i., pp. 4 seq.) as sung by a blind beggar in $S_{44}$. According to this version, the Count had gone hunting to find a bit of game, a partridge or hare, for the capricious appetite of his lady so soon to be a mother, and had in the wood come upon a fairy, who, on his refusal to marry her, gave him his choice between a lingering death of seven years and a swift death within three days. Tenderly he chooses:

"J 'aime mieux mourir dans trois jours,

Que rester sept ans sur mon lit;

Car ma petite femme est bien jeune,

Et clle aurait avec moi beaucoup de chagrin."

He returns home to his mother to die, the rest of the ballad following the lines of Count Arnaud. Miss Jewett's summary runs:

"The young Countess asks her mother-in-law what has happened to her husband that he does not come.

'He has gone shooting in the forest to bring you some little thing.' She asks what has happened in the household that she hears the servants weeping.

'They were bathing the horses, and the most beautiful is drowned.'

'They were washing and the water has carried off the finest linen.'

'A beggar lodged here and died in the night. He is to be buricd to-day.' She asks what to wear to church for her purification.

'It is the eustom to wear black.'

Arrived at the church, she asks:

'Who is buried under my bench, for the ground has been disturbed?'

'Until now I have hidden the truth. I can do so no more. It is your husband who is buried there."

And the ballad concludes:

"La dame comtesse, à ces mots,

Est tombée à terre sans connaissance;

Elle est tombée à terre sans connaissance,

Et est morte sur la placc."

This strangely moving story scems to have originated in the North, the Scandinavian ballads dealing with Sir Oluf (or kindred 
name) and his fatal encounter with an elf numbering some seventy. Of these a goodly proportion, especially of the Danish and Swedish versions, give the questions of the young wife and the evasive answers. As the folk-song wandered south and went out in many forms over France, Italy, and the Spanish Peninsula, the elfin adventure was all but lost, while the pathetic dialogue became the essential of the ballad. The name Oluf gave way to Renaud, Arnaud or Louis in France, to Anzolino, Rinaldo, Carlino in Italy, to Don Juan, Don Olalbo, Don Francisco, Don Pedro in Spain. Nigra discusses the history of the ballad under Morte Occulta (No. 2I) and notes resemblances to it in Mal Ferito (No. 22).

\section{COUNT ANZOLINO}

See note on preceding ballad, Count Arnaud.

\section{THE RING}

Nigra gives (No.66) eight Piedmontese versions of La Pesca dell' Anello and refers to this Neapolitan variant as one of a numerous group of local renderings. Among Miss Jewett's ballad papers was found another bit of Neapolitan translation, taken from this same second volume (p. I86) of the Canti Popolari collected by Casetti e Imbriani,- - a snatch of sea-song used by mothers as a lullaby:

"How beautiful far out at sea,

When the Madonna sails with me,

St. Joseph at the tiller standing

And Captain Jesus Christ commanding,-

To sail with angels for our crew

Far out upon the water blue!

Hail to the sailor and the sea!"

\section{THE SHRINE OF SAN SIMÓN}

The translation of this very characteristic Spanish lyric, left unfinished by Miss Jewett, has been completed by the editor,the only poem in the book with which such liberty has been taken.

\section{THE MAIDEN IN THE GARDEN OF LOVE}

Victor Smith notes (Romania, vii., 6r) that this song has a literary, unreal touch upon it, although he found shepherds who 
knew it. In its more usual form, it closes on the platonic note of the fifth stanza.

\section{THE BIRD MESSENGER}

As Child observes (No. 96, The Gay Goshawk), birds are "not seldom employed as posts in ballads," adding: "For a lovemessage of a general sort, not involving business, the nightingale is usually and rightly selected." Child notes that the falcon, the dove, and the parrot all do ballad errands, and Nigra (under No. 22) adds to the list the lark, the raven, the eagle, and the swallow.

\section{THE KING'S SON}

In different versions of this ballad, the action is variously localized, but the idyllic tone is maintained. Miss Jewett notes: "One listens in vain in the British ballad for such a strain as

'The roses are all fallen, And the sage is witherèd,' but its grace is characteristic of the country from which it comes."

\section{ADIEU, MARGUERIDETTE}

This fashion of folk-song, sparkling with riddle and repartee and involving the idea of metamorphosis, is discussed by Nigra under Amor Inevitable (No. 59). Amor Inevitable begins with the question:

"What will she do, the beauty, to flee from love?" and then the suitor's swift retorts pursue the flight of her fancy from dove that the hunter will take, to eel that the fisher will catch, to rosebush-hidden thorn that the nightingale will find, to cloistered nun that the friar will confess, even to the dead that the grave will embrace. Southern Europe abounds in dainty, whimsical variants, the Roumanian Cuckoo and Dove (Alecsandri, No. vii.) being peculiarly individual, but the direct representative of the class in British balladry (The Twa Magicians, Child, No. 44 ) is poor and gross. The literary type is more happily suggested by Riddles Wisely Expounded (Child, No. I), The Elfin Knight (Child, No. 2), and The Gardener (Child, No. 2 19), while the element of successive transformations makes a fleeting connection with Tam Lin (Child, No. 39) and The Earl of Mar's Daughter (Child, No. 270). 


\section{DONNA LOMBARDA}

Nigra opens his Canti del Piemonte with this powerfully tragic ballad, of which he gives no less than sixteen versions. From Piedmont the song has made its way over all Italy. Not mentioned in print until 1838 , it is now familiar to students of fo'lssong every where. Miss Jewett, who discusses it in her Introduction to this collection, counted it the most dramatic of all ballads.

\section{THE POISONED LOVER}

This dialogue ballad, whose great British analogues are Lord Randal (Child, No. 12) and Edward Edward (Child, No. I3), has been popular in Italy for some three hundred years. Its opening lines, together with an epitome of the tragedy, figure in a medley printed in a Veronese broadside in 1629 . As the ballad makes its way north, a tendency has appeared, especially in Germany, to change the dramatis personce. The central fact of poisoning by serving up for food snakes in guise of eels or other fish persists, but it is often a stepmother, or step-aunt, or step-grandmother, or mother-in-law, or sister-in-law who thus murders a helpless child or a bride.

\section{THE MAIDEN OF SAINT-MARTIN-DE-L'ILE}

With this French ballad our Young Johnstone (Child, No. 88) has some features of resemblance, but is hardly a genuine analogue. As Miss Jewett notes: "The assertion that human blood on the weapon or the clothing of a murderer is the blood of some animal is found elsewhere in ballads." Pointing out that, in comparison with Young Johnstone, the French ballad is greatly weakened by its appeal to legal justice, Miss Jewett says: "The brother of the murdered woman meets the murderer and accuses him, but instead of striking him down where he stands, goes tamely to court and begs for punishment of the murderer and of the wicked old mother who urged him on." Against this staid behavior she places that of Lord Thomas (Child, No. 73 D) who, when the brown bride's stab has slain Fair Annet, "takes the vengeance of a mad heart."

"Lord Thomas he had a sword by his side,

As he walked about.the hall;

He cut off the bride's head from her shoulders, And he threw it against the wall." 


\section{THE MURDER OF THE SWEETHEART}

This " fine and cruel ballad, " as Miss Jewett styles it, represents a class very numerous on the Continent. (Sce Nigra under La Moglie Uccisa, No. 29.) Victor Smith printed with this in Romania (vol. x., pp. 194-21 I) fourteen more French folk-songs of bloodshed, recounting murder of husband, father, sister, child, and other peculiarly startling and revolting crimes.

\section{FAIR JEANNETON}

In another French version of this ballad (given by J. F. Champfleury in Chansons Populaires des Provinces de France, p. 172) there flashes out in the dying lover something of the same quality that illumines this. With a care, even in his drowning struggle, for the maiden's safe return, he asks: "Who will conduct you, my Beautiful, back to your father's castle?" Her reply, even by ballad standards, lacks amiability. "It will not be you, wicked baron, for the fisines will have eaten you!" And, unrelenting, she calls to a fisic.man to be her escort home. The "penknife" figures in al" bailadry, especially in the English and the German. See following note on A Heroine.

\section{A HEROINE}

Miss Jewett notes: "Prof. Child says that no ballad in all his collection is so widely distributed as the various versions of Lady Isabel and the Elf-Knight (No. 4). In many folio pages he cites the analogues, Norse, Swedish, Danish, German, French, Italian, Spanish, Polish, Slavic and the rest. Collected, these variants of the one theme would make a huge volume. The fact of the wicked wooer being elfin, a wonder-worker, seems non-essential to the plot. The essential is his Bluebcard character, and the fact that, at last, vengeance overtakes him at the hand of one whom he would have added to his long list of victims." Nigra (No. 13) counts among the parallels of this ballad the French Fair Jeanneton (preceding) and the Spanish Rico Franco (following). Child notes (vol. i., p. 42) that the French versions are "generally found in a form resembling the English; that is to say, the scene of the attempted murder is the sea or a river (as in no other but the Polish), and the lady delivers herself by an artifice." Child hesitates to accept Professor Sophus Bugge's "entirely 
novel and somewhat startling hypothesis that all this great group of ballads constitutes a wild shoot from the story of Judith and Holofernes."

\section{THE BALLAD OF RICO FRANCO}

See preceding note on $A$ Heroine.

According to Child (vol. i., p. 44), Rico Franco is the earliest ballad on this almost universal theme to be printed in any language.

\section{COUNT GARÍ}

The collectors were able to find only one version of this very spirited ballad.

\section{LAMENT OF MARIA FELICE DI CALACUCCIA FOR THE DEATH OF HER BROTHER}

Marcaggi notes: "Les deux derniers vers de ce vocero servent d'épigraphe au beau livre de Prosper Mérimée, Colomba."

\section{THE MARQUISE}

This ballad, which Bladé believes to relate to Madame de Montespan, is another proof, he says, of the rapidity with which historic events are transformed into legends. He points out that the marquisate of Montespan was not in the Baise valley, but lay a little farther to the west, where the ruins of the chateau may still be seen.

\section{BUJOR}

(See note on The Sun and the Moon; also Introduction.)

This Roumanian ballad is given in a French prose translation by Alecsandri, No. vi. Alecsandri comments on the great popularity of the Moldavian Robin Hood, still spoken of "with admiration and respect." The name Bujor, originally, it would seem, a nickname meaning Red-haired, is that of the bright young chieftain in Hélène Vacaresco's Songs of the Valiant Voivode. Miss Jewett has abridged as follows another famous bandit-ballad of Roumania (Alecsandri, No. xiv.; Codréan):

"Codréan is a brigand who disguises himself in a coarse wool mantle and a sheepskin cap. But he is beautiful and lithe. By 
a trick worthy of a border thief he wins a steed so swift that as it runs the valleys melt under its feet. When the guard come upon him, he invites them to eat of his 'stolen' mutton and to drink of his 'stolen' wine. Instead, they fire their pistols full at his breast. Codrean presses the bullets from his bloody wounds, loads his carbine with them, and returns the fire.

"When he is overpowered and taken before the prince, he is asked, as Bujor was asked: 'Hast thou slain many Christians while thou hast been ravaging this country?' 'Most high Prince,' he answers, 'I swear by the name of the Holy Virgin that I have never, since I first went forth as a brigand, slain Christians. Whenever I have met a Christian, I have shared with him like a brother; if he possessed two horses, I have taken one and left him one; if he had ten piastres, I have taken five and left him five; whenever I have met a poor man, I have hidden my blade and filled my hand with gold for the unfortunate; but when I have seen a Turk,--oh! then I could not resist the desire to cut off his head and throw it to the crows.'

"Codréan obtains leave to confess before he is executed. He humbles himself and says to the priest in a penitent voice: 'O my father, by thy holiness have pity upon my sufferings; undo my hands for an instant that I may make the sign of the cross. Alas! I would, before I die, pray to God and fulfill my duty as a Christian.' The good priest unties the right hand of the brigand, who suddenly draws from his breast a jewel of a dagger; he cuts the bands that imprison his feet; he slays the guard; he cries to his horse, who, hearing his voice, breaks from the stable and runs to him without bridle or saddle; joyous and proud, the steed scarcely touches the earth; it flies, mane and nostrils to the wind. The happy Codrean caresses his horse, springs swiftly upon it, hurls himself across the troop of guards, leaps the wall of stone, and cries as he leaps it:

"'To thee, Prince, the throne; to me, liberty and daring. Adicu, thou art not worthy of Codrean.",

\section{THE BROTHERS FRA DIAVOLI}

Pitré notes: "The so-called Devil Brothers were Ambrogio and Antonino Buzzetta. These devoted brothers, through their robberies and even more through the mad recklessness of their enterprises, always eluding the vigilance of the law, left their nickname a proverbial phrase in Sicily." He adds that the blind 
street-singers all know this ballad and that to him it seems to bear marks of an unlettered author.

The prison escape of the Fra Diavoli calls to mind the dashing ballad (Child, No. 186) of Kinmont Willie.

\section{THE THREE STUDENTS OF TOULOUSE}

Child, in his discussion of The Clerk's Twa Sons o Owsenford (No. 72), notes this Toulouse folk-song among others, saying: "There are ballads both in Northern and in Southern Europe which have a certain amount of likeness with 'The Clerk's Twa Sons,' but if the story of all derives from one original, time has introduced great and even unusual variations."

Nigra states (under No.4) that versions of The Three Students have been published in Provençal, French, and Catalan, as well as Piedmontese. The ballad, in his view, was "certainly born in France and perhaps upon the benches of the school at Toulouse." The story goes that on Easter of I33I or I335 some students of Toulouse, led by Americo di Bérenger, ran in noisy frolic through the streets of the city at the very hour when High Mass was being celebrated in the church. A scandalized dignitary, attended by an officer, came out and laid hands upon the ringleaders. Americo, to free a comrade, struck this great personage in the face. The city was in tumult, the young culprits were seized and thrown into prison, and Americo, with one other, subjected to the torture,all by way of keeping a holy Easter. Under the torture Americo "confessed," and his head, after it had been shaved to cancel the tonsure, was struck off by the public executioner. Not only his kinsfolk but all decent society protested in horror against such treatment of a scholar and a noble. Parliament punished Toulouse by suspending all its liberties and privileges and confiscating the property of its inhabitants. A magnificent funeral was given "the martyr." The dignitaries of the city and church abased themselves in vain. They themselves bore the mutilated body on its sumptuous bier to the grave and humbly entreated the pardon of the populace, but they were promptly deposed, and the students of Toulouse lived happy ever after.

\section{THE LADS OF GUÉRANDE}

This blithe lilt suggests that magic power of music known to folk-lore since Orpheus and Amphion. Our British balladry has 


\section{Notes}

traces of it in King Estmere (Child, No. 60) and Glasgerion (Child, No. 67) as well as in the confused verses of The Twa Brothers.

"She put the small pipes to her mouth,

And she harped both far and near,

Till she harped the small birds off the briers,

And her true love out of his grave."

(Child, No. 49 B.)

The most beautiful example in Southern folk-song is the Castilian Count Arnaldos, but this, though of more mystical quality, is akin to The Sailor and The Corsair rather than to The Lads of Guérande, whose closer parallel is the Piedmontese prison-song Poter del Canto (Nigra, No. 47).

\section{SHALGA}

This ballad is rendered into French prose by Alecsandri (No. xix., Chalga). Sec Introduction, and note on The Sun and the Moon.

The figure of this fierce young shepherdess, astride her rushing steed, is typical of the wild fighting energy of Roumania. In the very road of the northern migrations, crossed again and again by the invading Asiatic hordes, the battle-ground of Hungarians, Poles, Turks, Tartars, Muscovites, no wonder that Roumania has fostered heroines as well as heroes. The bond between a Roumanian and his horse is well illustrated by a passage from the ballad of The Roumanian Groué Grozovan (Alecsandri, ix.) which Miss Jewett has paraphrased as follows:

"The old Tartar Klian whose horse has been stolen by a Roumanian bandit, says sadly to the thicf:

"'Oh! Groué! famous heiduck! I pardon thee, but promise me that thou wilt never sell my black horse to a mountaineer; the mountaineers are men of tricks. Sell it to a Moldave; the Moldaves are richer, more generous; they have prouder spirits. A Moldave would take care of this beautiful horse, to parade it at fêtes and weddings, and if some day I meet it, its master may make me a present of it, or at least give it to me for thrice its weight in gold paid in Venetian ducats worth five piastres the ducat.'

"Groué answers smiling:

" Poor old Ghirai, thou forgettest that I am the son of a 
Roumanian. Now, since I am son of a Roumanian, dost thou not know that this brave strong horse is my own brother?"'

\section{THE FLIGHT INTO EGYPT}

For British ballads based upon Scriptural and Apocryphal subjects, see Introduction.

The Catholic countries have cherished, in song and ballad, many a quaint and tender legend of the Nativity. The courteous tree that bent its fruitful boughs to Mary, an apple-tree in this Provençal telling, is a cherry-tree in the English ballad, elsewhere a fig-tree, elsewhere a date-palm. Southern France and Spain abound, even more than Italy, in well-beloved legends of Madonna and Child. Damase Arbaud noted (1862) that The Flight into Egypt was still sometimes sung by the peasants of Provence before the crèches in the churches. Among Miss Jewett's balladpapers were found the following renderings, penciled and unrevised, of such Nativity folk-songs.

\section{THE THREE KINGS OF THE ORIENT}

\section{(Sicilian. Palermo)}

(From Pitrè, G.: Canti Popolari Siciliani, vol. il., pp. 331 seq.)

Upon the holy night of the first Christmas, A star appeared in the Eastern sky a-shining; Among themselves said the three Eastern Mages: "To us is born Messiah, we are contented." For thirty days with the one thought they travelled, Following the star in the Eastern sky a-shining, And came at last to a cave in the country, And found Christ folded in the arms of Mary. The first who spoke was the king Gaspar, saying: "O very son of the eternal Father, How art thou come down ta this poorest country, Thou who art Lord of squadrons of bright Angels? Now I am come with these my good companions, We are come journeying from a far country; Oh, pardon me: I bring thee this gold treasure, That may make rich my soul when I am dying." Oh, how accepted and how nobly worthy The tears that then were shed by Baldassare! 


\section{Notes}

Saying: "O God of the Celestial Choirs, Oh, take away my sins, for I am guilty. I bring Thee incense here to do Thee service, A sacrifice I make most rare and precious; I bring Thee incense here, $\mathrm{O}$ my Redeemer, O Thou High Priest and very God and Saviour." And last of all came Melehior and offered;

Sweet frankincense and myrrh he offered, weeping: "Take thou this precious myrrh, take it, my Jesus, Because thy wounds and sorrows shall be many." When Mary all their precious gifts had taken, She undressed the little Baby Christ before them. They kissed the tiny feet of the Child, weeping, And thus they would take leave of Him, all weeping. An Angel of the Lord appeared before them: "O noble Kings, change roads for your returning; For if word comes to murderous King Herod, He will slay the Child upon the breast of Mary." Then the three Kings adored the Baby Jesus, And bade farewell to Joseph and to Mary; And toward their homes another road they journeyed, Even as the Angel of the Lord commanded.

\section{THE THREE KINGS}

(Catalan)

(From Briz, E. P.: Cansons de la Terra, vol. iv., pp. I 79 seq.)

The light of a star shining

They see it far and wide;

The sun cannot dim it, The clouds cannot hide.

Shepherds and sages, Seers of Bethlehem, Leave watching and folding, Men of Bethlehem; Make haste now, beholding How bright the star's light, The star's light. 
The star in its travel

To Bethlehem went;

This is a marvel

Of the Omnipotent.

Guided by the star's shining,

Eager and attent,

There are seen coming

Three Kings of Orient.

Eager and watchful, The star leading them, Three Kings are seen coming Far off toward Bethlehem.

The Three Kings are coming

From out the Orient

To see and to worship

This new divine portent.

With camels and pages

Come riding the Three Kings;

With big bells of silver

Every bridle rings.

Shepherds and sages,

Seers of Bethlehem,

Leave watching and folding,

Men of Bethlehem;

Make haste now, beholding

How bright the star's light,

The star's light.

Many of the cradle-songs of Southern Europe derive their especial beauty from the memory of the Madonna, like the Neapolitan one cited in the note on The Ring, and like this of Sicily, also in Miss Jewett's rendering:

"My little child, so sweet to me,

I am the honey, thou the bee;

So sweet was never any other

But the Baby Jesus to his mother; 


\section{Notes}

"Thou art the light, the stars, the sun,

My little child, most lovely one!

I make the cradle soft and deep,

And lay thee lightly down to sleep.-

Lulla-by!"

\section{MARY MAGDALENE}

See Introduction for the treatment of the Magdalen in folksong.

In the late Miracle Drama of England is a play, preserved in a manuscript of the early sixteenth century, of Mary Magdalen. Through fifty-one rambling scenes it carries her life on to the cavern where she lived thirty years in penitence, being thrice a day lifted up into the clouds and fed with manna. The English view of the Magdalen is not always so kindly. At Launceston in Cornwall, for instance, where the outer walls of the great granite church are covered with claborate carving, the sculptured figure of Mary Magdalene at the west end is regularly-this alone among all the figures-stoned by the boys, so that flints and pebbles are lodged all over the poor image, which lies on its face in an attitude of extreme dejection.

\section{SAINT MARY MAGDALENE}

See preceding note on Mary Magdalene.

The presence of St. John at the funeral is natural, for the medieval legend includes John, who is said to have been Mary Magdalene's first lover. Her chagrin and grief, when he forsook her to follow the Christ, drove her into a life of open sin.

\section{THE SAMARITAN WOMAN}

See Introduction for the place of the Samaritan woman in folk-lore. The identification of her with the Magdalen is discussed, also, by Child under The Maid and the Palmer (No. $2 \mathrm{I}$ ). Certain variants of this Catalan ballad close more austerely, with threat of Hell in case the woman returns to a life of sin.

\section{THE WICKED RICH MAN}

See Introduction for the characters of Dives and Lazarus in folk-song.

Arbaud states in 1862 that this was the favorite ballad of the 
Provençal peasantry, - that it was still not uncommon, in certain districts of Provence, to hear old beggars, going from door to door, recite this ballad in a solemn and melancholy tone. Among the mendicants of the Spanish Peninsula, too, its variants are very popular.

Miss Jewett has, in the next to the last stanza of this ballad, substituted in her text the reading as given in Cansons de la Terra for that of Arbaud, which is:

"Prend lou, trai lou es oundos

Es oundos de 1'Infer."

"Hai! paure iou! sur terro

N'en ai pas proun suffert."

Arbaud adds two more stanzas which apply the moral:

Se d'aqueou marri riche

Vouretz h'aver lou sort,

Donnetz l'oumoin' es paures;

A l'honro de la mort

L'oumoino qu'auretz fasho

Cumptara davant Diou

Mai qu'em autro bonen' obro,

Fouguessiatz-ti judiou.

This ballad may well be compared with La Madonna e Il Riccone translated into English verse by Francesca Alexander in Roadside Songs of Tuscany.

\section{THE WICKED RICH MAN AND THE BEGGAR}

See preceding note on The Wicked Rich Man.

The simplicity and comparative brevity of the Catalan versions of the Dives story are so marked that it is thought by folk-lore scholars they may have developed out of cradle-songs.

\section{THE PRODIGAL SON}

On this sacred ditty, sung by the Sicilians as lightly as their lays of brigandage and of romantic love, see Miss Jewett's comment in the Introduction. 


\section{ST. JAMES OF GALICIA}

The shrine of Santiago in the northwestern corner of Spain, still the goal of pilgrimage, was the third in rank of medieval Christendom. Indeed, the cockle-shell of St. James has outstripped, as a pilgrim symbol, the keys of Rome and even the cross of Jerusalem.

The miracle of the reanimated cock is found, also, in ballads of the Nativity, as St. Stephen and Herod (Child, No. 23) and The Carnal and the Crane (Child, No. 55). Its usc in that connection Miss Jewett sometimes illustrated in her classroom by the following stanzas from a Danish version of St. Stephen and Herod as translated by Prior (in Ancient Danish Ballads, vol. i., p. 398).

St. Stephen saw the star's bright sline,

As he his horses drave;

"Of truth is now the Prophet born, Who all the world shall save."

"On Stephen's tale," King Herod said, "No faith will I bestow,

Unless this roasted cock stand up And clap his wings and crow."

Straight clapp'd his wings the cock, and crow'd, "Our Lord is born to-night."

From off his throne King Herod fell, And swoon'd away for fright.

$U_{p}$ rose the King, and mounted horse, To Bethlehem town to ride;

He fain that little child would kill, Who all his power defied.

But Mary took in arms her babe, Joseph his ass's rein,

And so through Jewish land they rode To Egypt's sandy plain.

Full fourteen thousand babies small

The tyrant caused to slay;

Jesus, ere sank the sun to rest,

Was thirty miles away. 
"The ultimate source of the miracle of the reanimated cock," says Prof. Child (vol. i., p. 239), "is an interpolation in two late Greek manuscripts of the so-called Gospel of Nicodemus: Thilo, Codex Apocryphus Novi Testamenti, p. cxxix $f$.; Tischendorf, Evangelia Apocrypha, p. 269, note 3." "The crowing cock," Miss Jewett notes, "occurs here in the story of Judas and is found thus in the Cursor Mund, vv. 1596I-998."

That an innocent victim of the gallows or the cross should be sustained by angels is, too, a familiar miracle in folk-song.

A paraphrase of this ballad, expanded and addressed to children, was made by Robert Southey under title The Pilgrim to Compostella.

\section{COUNT ARNOLD}

For this and for all the ballads following, see Introduction on the element of the supernatural in folk-song.

Milá states (in Observaciones sobre la Poesia Popular, con Muesiras de Romanes Catalanes Ineditos) that there are few traditions in Catalonia so vivid and so sharply localized as this of Count Arnold. Most of the ghost-features of the ballad,- the spirit clad in the flames of its burning, the sudden, midnight entrance through grated windows, the summoning cock-crow, the longing of the tortured soul to look again upon what was once its own,are of world-wide familiarity, but the horse's peculiar taste in fodder may arrest attention. A horse resembling him somewhat in this respect may be found in Helène Vacaresco's Songs of the Valiant Voivode in the ballad of The Four Princesses and their Crimson Slippers.

\section{THE SONG OF THE LOST SOUL}

This is an interesting variant of the Dives theme, for in the case of this rich man doomed to hell it is not the refusal of alms that is charged against him, but the persistent withholding of payments due to workingmen and tradespeople. Count Arnold, too, whose gold was "ill-gotten," suggests in his cautions to his lady that he had been remiss in paying wages. (See preceding ballad.)

\section{THE YOUNG GIRL AND HER MOTHER'S SOUL}

Two versions of this ballad were contributed to M. Luzel by Breton peasant women. The ballad given is the one directly 
used by Miss Jewett, but her translation is colored by the other, whose title it takes and whose fuller account does much to rationalize the story,-so far as a ghost-story may ask to be rationalized. It seems that the daughter's longing to see her mother was met by the priest's suggestion that she await, in the church, the hour when spirits walk, and lay an apron on her mother's tomb. But the daughter's excessive grief had so enhanced the mother's torments that the furious ghost tore the first apron into nine pieces, the second into six, and the third into three, and might, after the fashion of furious ghosts (see Child's discussion in connection with The Suffolk Miracle, No. 272), have torn her daughter into pieces likewise, had not the girl meanwhile stood godmother to a sister's child and given it their mother's name.

The midnight procession of the dead is still looked for with terror in many a peasant home of Southern Europe. In Galicia it is often merely a line of shining tapers that walk the darkness,tapers that have a way of pausing under open windows while the foremost begs to be taken in and kept safe till morning. Should you comply, the dawn discloses a wax-cold corpse lying where the taper had been, and at midnight the terrible candles return to claim their leader and burn you "to fire and ashes."

\section{THE DEAD MOTHER RESTORED}

Nigra states (under No. 39) that fuller versions of this ballad have been found in French and Provençal. In these, the neglected children go to the cemetery to find their mother and meet on the way Christ or Peter or John, by whose miraculous word the mother is restored to care for her little ones for seven years, or for seven years and a day, or for fifteen years. At the expiration of the allotted period she tells her children, weeping, that she must return to her grave, and they, striving to comfort her, go with her to the very brink.

\section{THE MOTHER'S CURSE}

This ballad is very popular in Italy. Nigra (under No. 23) prints six versions and lists a number of others. The general theme of the fatal power of a mother's curse is not unfamiliar to Northern folk-song, but is embodied in different incidents. Our nearest British parallel is The Mother's Malison, or, Clyde's Water (Child, No. 216). 


\section{THE ACCURSĖD}

Transformation plays a considerable part in folk-lore everywhcre. The maiden who puts on the shape of a white hind to sport in the forest, the maiden whom the silver wand of a witch has turned into "an ugly worm," the maiden enchanted by her wicked stepmother into "a fiery snake," are old acquaintances, but this French case of the blacksmith's daughter accursed into a mule has apparently no parallel in British balladry.

\section{THE VOICE FROM UNDERGROUND}

Miss Jewett translated this most poignant poem from the Italian of Tommaseo. It is rendered into French, too, by Fauriel in his Chants Populaires de la Grèce (vol. ii., p. 40I). In this same volume of the Chants Populaires (p. 433) Miss Jewett came upon a Greek cradle-song and, at first reading, it would seem, began to write it out, in rhyme or not, as it came to her, but inevitably in rhythm. It was found unfinished among her ballad-papers.

"Sleep, bring my son to me!

I have given him three sentinels,-

Three sentinels, three guardians,

And strong are all the three.

For guardian upon the mountains,

I have given him the Sun;

For guardian on the plains, the eagle;

And on the sea the fresh North Wind."

The Sun sets, and the Eagle sleeps,

And the North Wind goes to his Mother.

"My little one, where wert thou yesterday, And where the day before, and through the nights?

Wert thou perchance in talk upon thy way

With sun and moon and with Orion's lights?"

\section{THE LITTLE LAMB}

This Roumanian ballad was first found by Miss Jewett in the French prose of Alecsandri (La Petite Brebis, Miorita, No. I). See Introduction, and note on The Sun and the Moon. Alecsandri 
states that the close of the ballad is lacking and that all his efforts to recover it were fruitless.

The loving relations between the Roumanians and their animals is illustrated by the tradition that the river Moldava and the land Moldavia were so named by a Roumanian chicf after his faith. ful hound Molda. A passage in Hélène Vacaresco's Songs of the Valiant Voivode (p. 4I) is of double significance in its bearing upon this ballad:

"Dost thou know the way to the moon, O shepherd?

Dost thou not regret the earth, And thy dog, and thy sheep, and thy mantle, And the mountains where the bears are black?"

"Give me thy kiss. I 'Il die and take thy message to the moon; But please, white fairy, don't tell my dog,

Don't tell my sheep and my mantle

That I am dead.

Tell them I ' $m$ betrothed to the fairy

Who lives in the distant moon."

The longing of the shepherd to lie, in death as in life, within hearing of his flock, is like the prayer of the Greek sailor noted down by Miss Jewett from Tommaseo's Canti (vol. iii., p. $32 \mathrm{I}$ ):

"The sailor dying at sea prays: 'That they may not bury me in church nor monastery, but at the edge of the shore, down there in the sand. There the sailors come, and I shall hear their voices."

Though the Roumanians have a folk-saying, "The Roumanian never dies," many of their songs are songs of desperate courage in the face of death. Two of these, which Miss Jewett translated from the German of Schuller, stand here in evidence:

THE SOLDIER'S FAREWELL

\section{MAIDEN}

Sweetheart, thou goest; if thou must go indeed, What shall become of me, in my great need?

SOLDIER

My little darling, luck shall come to thee;

Take heart, for there are many lads like me. 


\section{MAIDEN}

Let all the lads stand up here in a line;

Without thee, they are nothing, Love of mine!

Let all the lads stand up here file by file,

I know to whom my heart belongs the while.

\section{SOLDIER}

Listen to me, thou knowest what must come;

I can no longer stay with thee at home.

Yonder where I needs must go,

Mountains rise and rivers flow;

Not a flower its white can keep,

There where blood runs ankle-deep;

Not a grass blade may we see

Where we wade blood to the knee.

A dreadful land; dear, seek another way;

Our loves must wander, wander from to-day.

THE SOLDIER TO HIS MOTHER

Mother, I must go away

To be a soldier; thou wilt stay

And wash my linen in thy tears,

And dry it, weeping bitter tears;

Mother, thou must have it sent

Yonder to my regiment;

There where lying on the ground,

Shot to death I shall be found;

Saber-slashed from foot to head,

Crushed beneath the horses' tread.

But this ballad of the young Moldave is Roumanian in its beauty even more than in its courage and its sorrow. It has a breath upon it like the freshness of the early morning; it touches the golden borderland of mythology. A simpler instance of the myth-making genius of the Roumanians is found in the ballad of Hercules which Miss Jewett rendered from the French prose of Alecsandri (No. 2). This ballad, he claims, is but a personification of the three divisions of Dacia (Transylvania, Wallacia, and Moldavia), but how instinctive the imagination that thus transmutes geography into poetry! 


\section{Notes}

\section{HERCULES}

"There were three maidens, sisters, who went at the dawn to gather flowers: the eldest sister has followed the course of the Tcherna; the second sister has entered the garden on the bank; and the youngest, the wildest of the three, has gone up stream along the shore. Many gallants, ready for love, have followed their paths, singing gayly, and have come back shedding tears; but behold! a young and fair captain, named Hercules, appears upon the banl: He pauses and speaks thus to the Tcherna:

'Limpid Tcherna! stay thy course and speak to me of the three sisters who went to gather flowers at the dawn.'

'The eldest sister has gone toward an enchanted region down the Danube, beside the sea; the second has left the garden and is lost in the depths of the ancient forests, beyond nine great mountains; the youngest sister, the wildest of the three, groans and weeps there under that roek, hidden in a profound shadow.'

Hercules, the brave captain, spurs his horse. One bound, the bank resounds, and there he is beside the weeping rock.

'Come forth from the rock, maiden; appcar to me.'

'Alas! how shall I come out from the rock since I am naked? I fear the Sun, I fear to be absorbed by his rays.'

'Have no fear, wild maiden; I will take thee in my arms that I may renew my powers; and I will shelter thee from the caresses of the wind, and from the burning kisses of the sun.'

' $O$ my beloved hero; if $I$ am dear to thee and if thou wilt make me thy companion, draw me forth from the deep shade of this rock, and I will appear in the sunlight, with my heart full of love.'

Hercules, the brave captain, struck the rock with his foot and suddenly he saw rise from it a maiden quite naked. She was white, she was beautiful, she was sweet and alluring; her golden hair waved over her shoulders.

Hercules took the maiden in his arms, pressed her against his heart, and at the contact he seemed born again; then he caressed her sweetly, and made for her a bed of odorous flowers, a nest hidden in the shadow, in shelter from the Sun." 



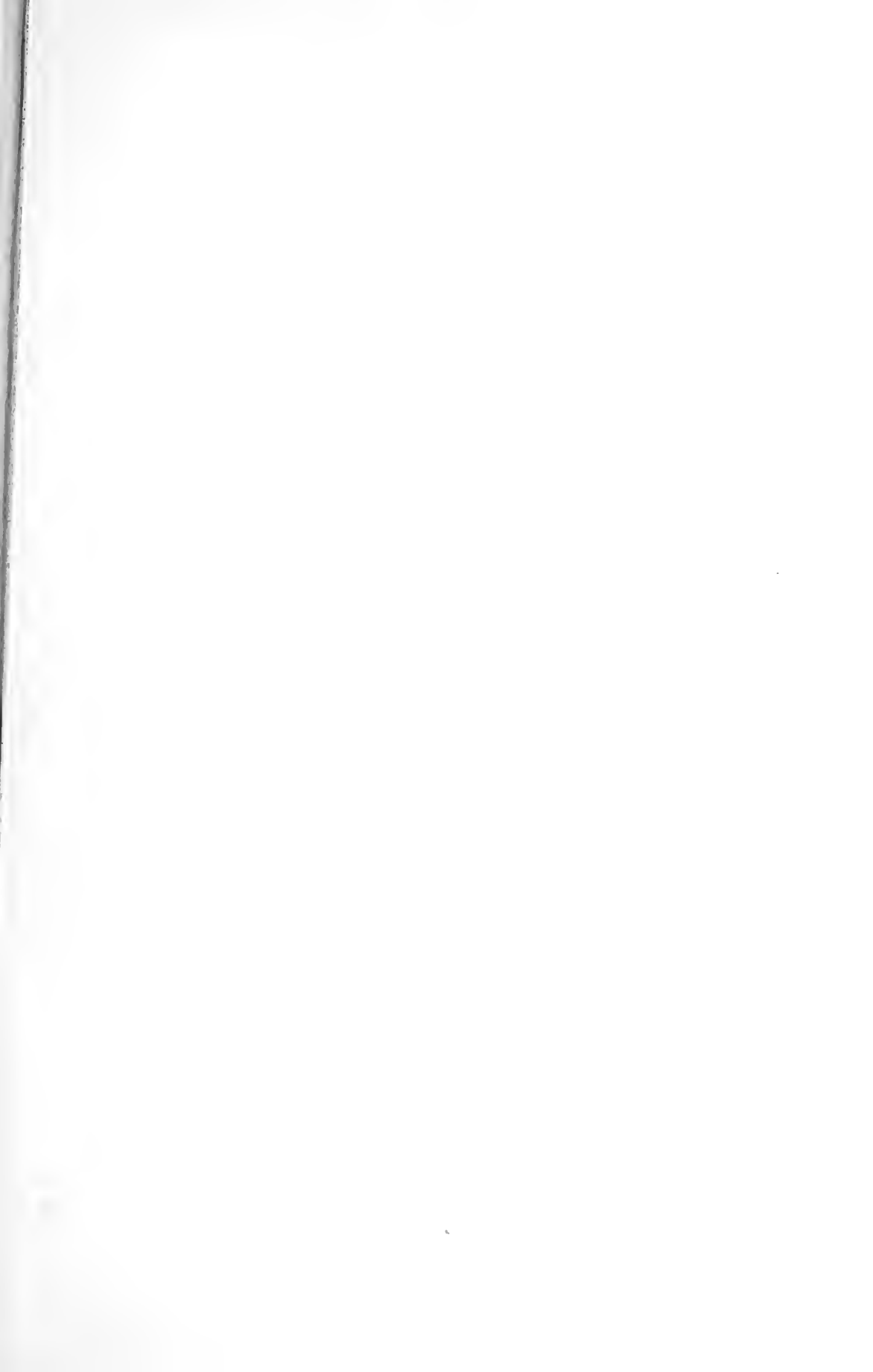





UNIVERSITY OF CALIFORNIA LIBRARY

Los Angeles

This book is DUE on the last date stamped below.

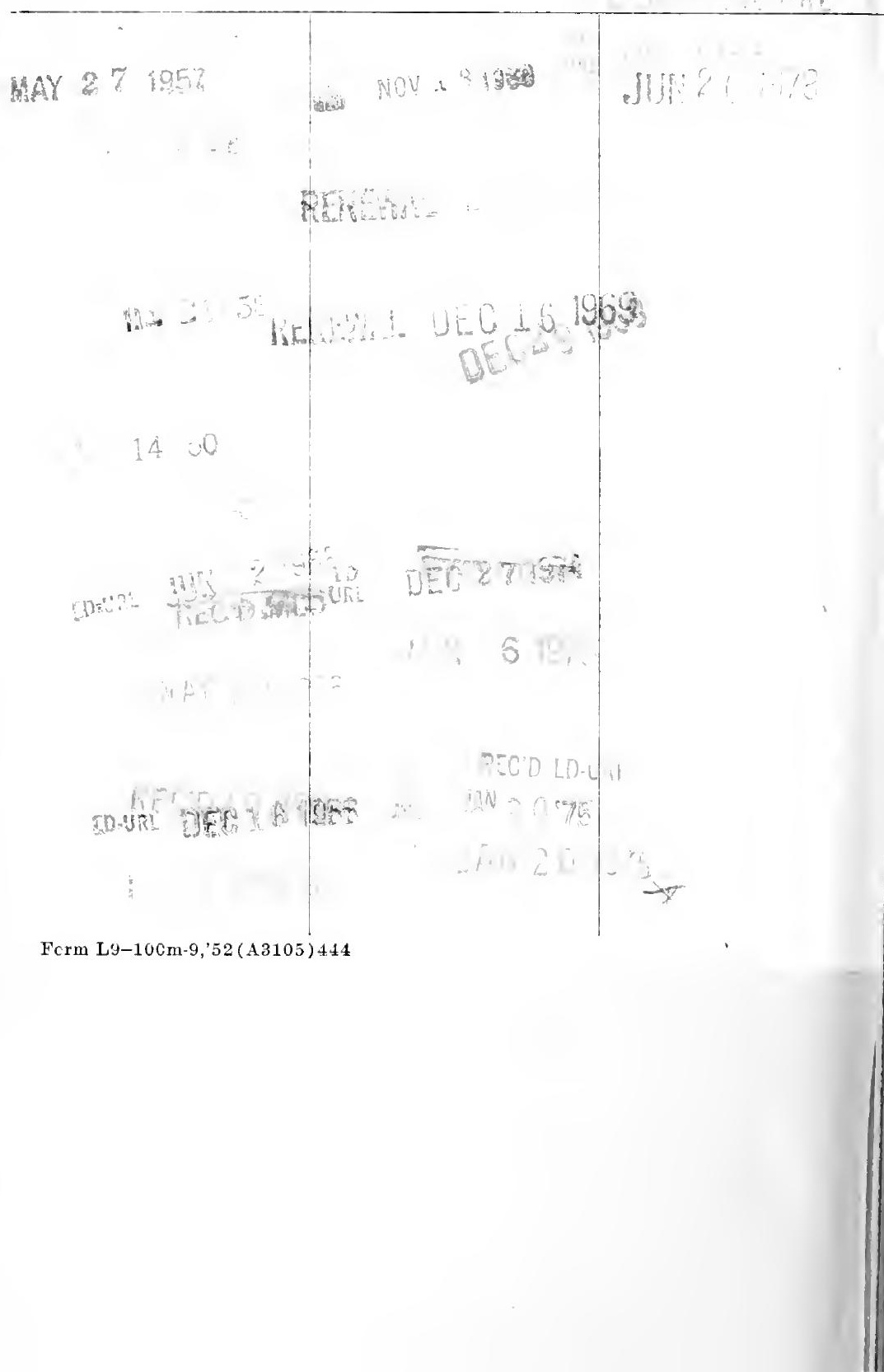




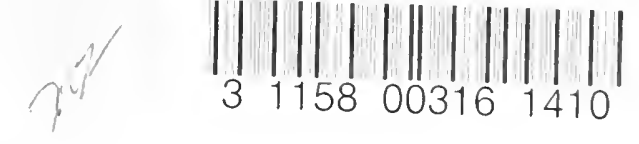




\section{Fin}

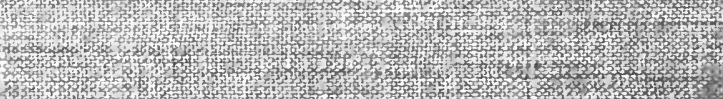

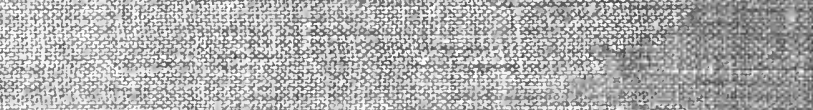
Fin.
H.t.
F
(x)

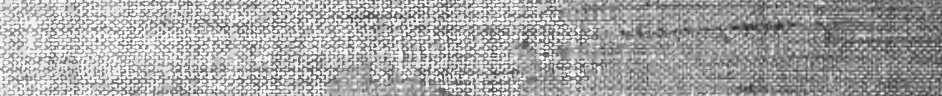
Mr

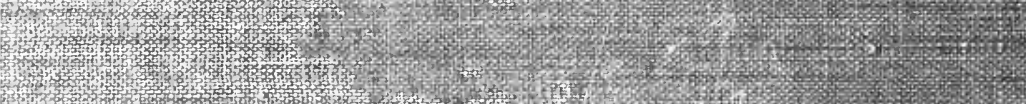
H.t. W. H.

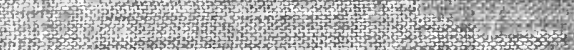

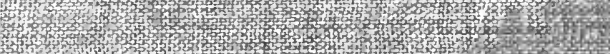
Fim H.

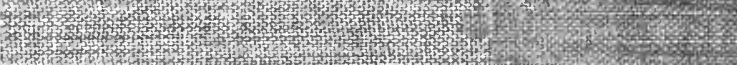

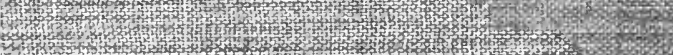
H.t. , H.t.

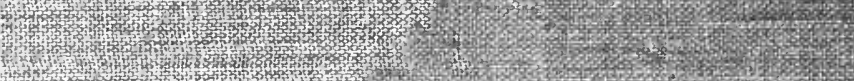

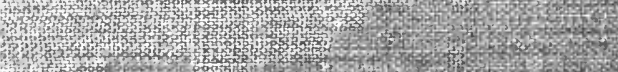

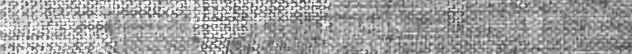

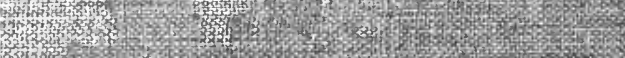

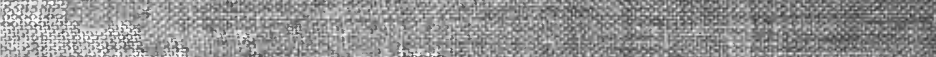

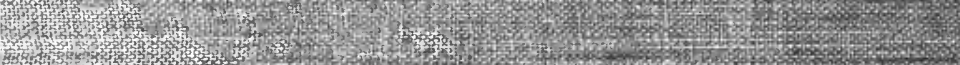
B.t. W. n.t. $n$
$H$ Tht W. 